\title{
SCRIPTA ISLANDICA
}

\author{
ISLÄNDSKA SÄLLSKAPETS \\ ÅRSBOK 70/2019
}

\author{
REDIGERAD AV \\ LASSE MÅRTENSSON OCH VETURLIĐI ÓSKARSSON
}

\author{
under medverkan av \\ Pernille Hermann (Århus) \\ Else Mundal (Bergen) \\ Guðrún Nordal (Reykjavík) \\ Heimir Pálsson (Uppsala) \\ Henrik Williams (Uppsala)
}

UPPSALA, SWEDEN 
(C) 2019 respektive författare (CC BY)

ISSN 0582-3234

EISSN 2001-9416

Sättning: Ord och sats Marco Bianchi

urn:nbn:se:uu:diva-400599

http://urn.kb.se/resolve?urn=urn:nbn:se:uu:diva-400599

DOI: 10.33063/diva-400599 


\section{Innehåll}

Ada Kan, Lars LönnRoth och Agneta Ney, Elena Gurevich (19572018). Minnesord .......................... 5

ANDERS HultgÅRD, Om Vafprúðnismál $\ldots \ldots \ldots \ldots \ldots \ldots \ldots$

ANDRAs MoRTEnSEn, Færeyinga saga som historisk kilde: En vurdering af sagaens ophavssituation og politiske miljø ....... 17

GuĐmundur Ólafsson og Lise Gjedssø Bertelsen, Det henrettede par i dobbeltgravhøjene i Kópavogur syd for Reykjavík i Î́sland. . 37

Hubert Seelow, Sjö plánetur í ljóðmaelum: Ein isländisches Gedicht über die Planetenkinder. Mit einem Exkurs: Kritische Anmerkungen zur Laienastrologie und Laienphilologie ....... 61

MatTeO TARsi, Instances of loanword/native word textual variation in the manuscript transmission of Egils saga Skallagrimssonar and Gísla saga Súrssonar .................... 87

\section{Recensioner}

Marianne Kalinke, Rev. of Natalie M. Van Deusen. The Saga of the Sister Saints. The Legend of Martha and Mary Magdalen in Old Norse-Icelandic Translation ........................ 105

OlOF SUNDQvist, Rec. av Anders Hultgård. Midgård brinner. Ragnarök i religionshistorisk belysning . . . . . . ............. 111

\section{Isländska sällskapet}

Berättelse om verksamheten under 2018 . . . . . . . . . . . . . . 119

Författarna i denna årgång . . . . . . . . . . . . . . . . . . 121 



\title{
Elena Gurevich (1957-2018) Minnesord
}

\author{
AdA KAN, LARS LÖNNROTH OCH AgNETA NEY
}

Elena Gurevich föddes den 5 januari 1957 i Moskva som dotter till den berömde historikern Aron J. Gurevich (1924-2006). År 1979 avslutade hon sina grundstudier vid filologiska fakulteten vid Lomonosov Statsuniversitetet i Moskva. Hennes ämnesinriktning var germansk filologi. Fyra år senare försvarade hon sin licentiatavhandling The System of Old Icelandic Poetic Synonyms. Elenas handledare var professor Olga Smirnitskaya. Därefter innehade Elena en akademisk tjänst i germansk filologi vid nämnda universitet i Moskva (1986-1990). Hon medarbetade tidigt i den av John Lindow, Lars Lönnroth och Gerd Wolfgang Weber utgivna antologin Structure and Meaning in Old Norse Literature (Odense 1986). Under många år var hon sedan forskare vid Avdelningen för klassisk västerländsk litteratur och komparativ litteraturforskning inom Institutet för världslitteratur vid Ryska Vetenskapsakademien i Moskva (1990-2018), där hon samarbetade med den välkände ryske folkloristen och litteraturteoretikern Eleazar Meletinsky (1918-2005). Under den tiden försvarade hon sin doktorsavhandling "The genre of pattir in Old Norse literature" (2007). Bland Elena Gurevichs monografier kan nämnas Poèzija skal'dov [Skaldic Poetry], skriven tillsammans med Inna Matyushina (Moskva 2000), och Drevneskandinavskaja novella. Poètika "prjadej ob islandcax". [Old Norse novella. A study of genre in the Tales of the Icelanders] (Moskva 2004). Bland hennes översättningar och utgåvor av fornisländska texter kan nämnas Islandskie prjadi [Icelandic pattir]. Translations, Commentary and Introduction by Elena Gurevich, i Literary Monuments (Moskva 2016), och "Anonymous Pulur", i Skaldic

\author{
Kan, Ada, Lars Lönnroth och Agneta Ney. 2019. Elena Gurevich (1957-2018). \\ Minnesord. Scripta Islandica 70: 5-6. \\ (C) Ada Kan, Lars Lönnroth och Agneta Ney (CC BY) \\ DOI: $10.33063 /$ diva-400600
}




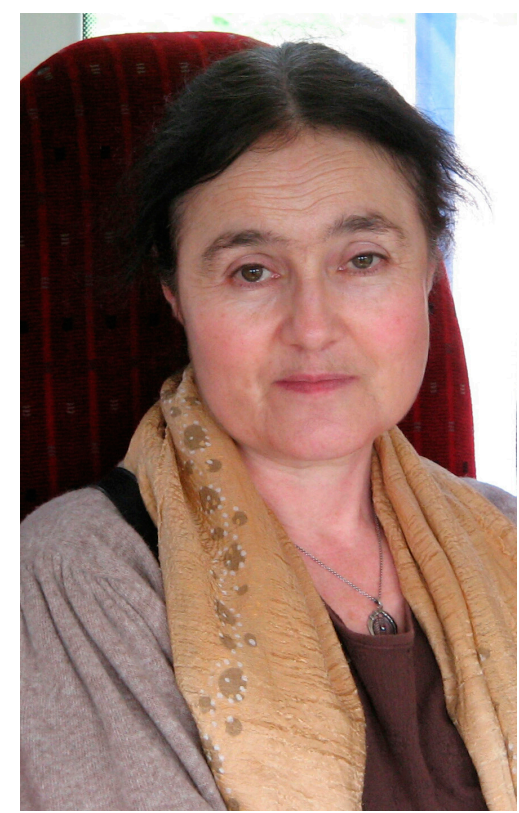

Elena Gurevich. Foto: Petrik Arkadiev (2012).

Poetry of the Scandinavian Middle Ages III: Poetry from Treatises on Poetics, ed. Kari E. Gade, Brepols Publishers (Turnhout 2017).

Vid The $14^{\text {th }}$ International Saga Conference i Uppsala 2009 var Elena Gurevich key note speaker med ämnet "From Accusation to Narration. The Transformation of the senna in Íslendingapattir" (Scripta Islandica 60/2009). Det var vid sådana vetenskapliga sammankomster som vi brukade träffas, men vid konferensen i Reykjavík år 2018 påmindes vi om Elenas allt för tidiga bortgång.

Elena Gurevich avled efter en tids sjukdom den 18 januari 2018. Hon efterlämnade sonen Peter Arkadiev, en framstående lingvist, doktor i baltiska och kaukasiska språk och forskare vid Institutionen för slaviska studier vid Vetenskapsakademien i Moskva.

Elena Gurevich var en originell och skarpsynt forskare som under inspiration från fadern och Eleazar Meletinsky vågade gå sin egen väg utan hänsyn till de akademiska värderingar som var gängse under Sovjetväldet. Hon fick tidigt kontakt med kolleger i Västeuropa och gjorde vetenskapliga insatser av bestående värde, speciellt vad gäller norrön poesi och poetik men även fornisländsk kortprosa. Hon kommer att saknas i den norröna forskargemenskapen. 


\title{
Om Vafprúðnismál
}

\author{
ANDERS HULTGÅRD
}

Eddadikten Vafprúðnismál anses tillsammans med Grímnismál utgöra en tillförlitlig källa till förkristen skandinavisk religion. Dikten tillhör en litterär genre som man kan kalla 'visdomstävlan'. Syftet med mitt bidrag är att se närmare på det ramverk som bestämmer diktens tillhörighet till denna genre. Uppbyggnaden av Vafbrúðnismál skulle enligt flera forskare vara inspirerad av medeltida europeiska genrer. Jag vill i stället sätta in diktens ramverk i ett vidare, jämförande sammanhang som stödjer dess ursprung i förkristen skandinavisk tradition. ${ }^{1}$

Vafprúðnismál betraktas i allmänhet som en av de äldre eddadikterna, tillkommen i en tid då kunskapen om de gamla myterna ännu var högst levande. ${ }^{2}$ Den lämpar sig för dramatisering och kan också ha framförts som ett stycke underhållning vid gästabud och annan samvaro. ${ }^{3}$

\section{Ramverket}

Dikten är hållen i dialogform och ramen är följande. Oden berättar för sin maka, gudinnan Frigg, om sin önskan att besöka jätten Vaftrudner för att

\footnotetext{
${ }^{1}$ Jag har tidigare behandlat Vafprúðnismál och dess uppbyggnad i Hultgård 2009 och Hultgård 2017: 122-132.

${ }^{2}$ Man pekar gärna på 900-talet, men dikten kan likaväl ha författats under första hälften av 1000-talet; för tillkomsttid och tradering se t.ex. Gísli Sigurðsson 2006; Machan 2008; Jónas Kristjánsson \& Vésteinn Ólason 2014: 176-177. Andra forskare lutar åt en senare datering; så Simek 2003; Simek \& Pálsson 2007.

${ }^{3}$ Jfr. Gunnell 1995; Kuusela 2017: 129.
}

Hultgård, Anders. 2019. Om Vafprúðnismál. Scripta Islandica 70: 7-16.

(C) Anders Hultgård (CC BY)

DOI: 10.33063/diva-400601 
ta reda på om denne är så kunnig som det sägs. Frigg tycker att ett sådant besök låter farligt men hoppas ändå att Oden skall komma välbehållen tillbaka. Oden ger sig iväg och når så småningom fram till en av jättens hallar. Han träder in och vill strax utmana jätten i en visdomstävling (fvn. orðspeki). Vaftrudner blir överraskad och frågar: "vem är den människan som tar till orda i min hall?' och fortsätter 'ut kommer du inte från våra salar såvida du inte är den kunnigaste". ${ }^{4}$ Oden uppträder under namnet Gagnråd, något fritt översatt: "den som ger goda råd". ${ }^{5}$ Vaftrudner bjuder nu in Oden men först sätter han honom på prov med några frågor vilka rör mytologin. Detta avsnitt har ett eget omkväde som lyder:

"Svara, Gagnråd, på detta, eftersom du på hallgolvet vill få din duktighet prövad"

Och så följer själva frågan, den första lyder:

"Vad heter den häst som drar fram dagen över människorna?"

Gagnråd kommer som väntat med rätt svar:

"Skinfaxe heter han som drar in den ljusa dagen över människorna"

Efter att Oden även svarat rätt på de återstående tre frågorna utbrister Vaftrudner:

Du är verkligen kunnig (fróðr), ta nu plats på jättens bänk!

Oden som hittills stått på hallgolvet får nu lov att sätta sig till bords med jätten.Vaftrudner meddelar så villkoren för tävlingen. Med huvudet som pant skall de båda ge sig in i kampen om vem som är bäst i vishet. Nu är det Odens tur att ställa frågor och de inleds också med ett omkväde som varieras något. Jätten klarar av att svara rätt på alla de mytiska frågor Oden ställer - även de som handlar om framtiden och Ragnarök. Men den sista frågan Oden ställer blir ödesdiger för jätten. Den lyder (strof 54):

Vad viskade Oden själv i sonens öra,

innan denne skulle bli lagd på bålet?

Med ens går det upp för jätten med vem han tävlade och han inser nu vad som väntar honom (strof 55):

${ }^{4}$ Det sägs inte rakt ut, men här sätter man sitt huvud på spel; jfr. Finlay 2011 och Kuusela 2017: 137.

${ }^{5}$ Några kommentatorer menar att Gagnråd är ett skrivfel för Gangråd, 'vandrare'; ett Odensnamn belagt i andra källor; diskussion hos Ejder 1960. 
Ey manni pat veit, hvat pú í árdaga sagðir í eyra syni; feigum munni mælta ek mína forna stafi ok um ragna røk

"Ingen människa vet vad du fordom sade i sonens öra; med dödsmärkt mun berättade jag gammal visdom och gudarnas öde"

Vaftrudners sista ord till Oden blir ett erkännande (strof 56):

Du är alltjämt den visaste av varelser.

\section{Fornvästnordiska paralleller}

Vafbrúðnismál är en skickligt uppbyggd text och visar vilken högtstående diktkonst som den muntliga traditionens poeter kunde skapa. Tillbaka till själva temat, tävlan i mytisk kunskap. Texter med ett likartat tema förekommer i den fornvästnordiska litteraturen och har med större eller mindre rätt lyfts fram som paralleller. ${ }^{6}$ De gammalnordiska företeelserna mannjafnaðr 'jämförelse mellan män' och senna 'ordträta' skulle ha påverkat Vafprúðnismál. Båda företeelserna utvecklades även till litterära genrer, oftast i dialogens form. En mannjafnaðr gick ut på att framhäva sig själv gentemot andra och den hade sin plats vid gästabud och dryckeslag. Sennan däremot hade som syfte att nedvärdera andra personer. Exempel på genrerna mannjafnaðr och senna är eddadikterna Hárbarðsljóð och Lokasenna. Båda dessa genrer har enligt min mening mindre värde som förklaringsmodeller till Vafprúðnismál.

Närmare ramverket i Vafprúðnismál kommer man genom den tävling i gåtor som Hervarar-sagan beskriver. Kung Heiðrek kallar till sig Gestumblindi, en man som han är ovän med. Denne kommer att mista livet om han inte framställer gåtor för kungen. Gestumblindi känner sin begränsning men blotar till Oden för att få hjälp. Guden ikläder sig Gestumblindis

\footnotetext{
${ }^{6}$ Om vishetsdiktningen i den poetiska eddan, se de Vries 1934.
} 
gestalt och lägger fram en rad gåtor som kungen inte trott att den medelmåttige Gestumblindi kunde tänka ut. Kungen löser alla gåtor utom den sista som är densamma som Oden ställer till jätten i Vafbrúðnismál: "vad viskade Oden i Balders öra innan denne blev lagd på bålet?”. Kungen inser nu med vem han har att göra och riktar ett hugg mot guden. Oden förvandlar sig till en falk och flyger därifrån. Samtidigt uttalar han spådomen att Heidrek ska bli dödad av sina trälar. Här är det visserligen fråga om liv och död men det gäller från början enbart den ene av de inblandade. Vidare är det bara Gestumblindi som framställer gåtorna vilka innehåller mest allmängods. Mytiska referenser saknas nästan helt. John McKinnell menar att både Vafprúdnismál och Hervarar saga oberoende av varandra bygger på en bakomliggande äldre tradition, där berättelsemönstret utgjort en tävlan mellan Oden och en mytisk eller legendär motståndare. ${ }^{7}$

Uppbyggnaden av eddadikten Alvíssmál som en slags frågesport där guden Tor ställer frågor till en dvärg vid namn Allvis, "den som vet allt", hör i stort till samma genre som Vafprúdnismál och Gestumblindis gåtor i Hervarar-sagan. Inledningen av dikten omtalar att dvärgen som bor nere under marken, kommer till Tors hall för att hämta hans dotter som brud. Guden ger sitt samtycke på det villkoret att Allvis kan svara på allt som Tor vill veta. Genom att hålla Allvis sysselsatt med upprepade frågor lurar Tor honom kvar i hallen tills dagsljuset skiner in, - och underförstått - att dvärgen nu mister livet. Men Alvíssmál innehåller inte någon egentlig tävlan. Tor prövar dvärgens kunskap i poetiska synonymer utan att själv behöva utsätta sig för besvärliga frågor från Allvis. Det rör sig om sådana spörsmål som vad ett ting eller ett fenomen heter bland olika grupper av varelser, oftast människor och gudar.

Eddadikten Fáfnismál låter (stroferna 12 till 15) Sigurd ställa några frågor om mytiska ting till draken Favner

Svara mig på detta, Favner;

man säger ju att du är kunnig

och väl känner till många ting.

Frågorna handlar om nornorna och den plats där eldsjätten Surt och gudarna skall mötas i en sista strid. ${ }^{8}$ Här är det inte fråga om en tävling i mytisk kunskap mellan två olika personer utan det verkar som om Sigurd vill bli upplyst om saker och ting han inte kände till förut.

\footnotetext{
${ }^{7}$ McKinnell 1994.

${ }^{8}$ Se Kragerud 1981.
} 


\section{Medeltida europeisk tradition}

Blickar vi ut över det medeltida Europa finns där genrer och texter som påminner om ramverket i Vafprúðnismál, och som även använts för att stödja antagandet att dessa påverkat utformningen av eddadikten. Man har allmänt pekat på medeltida lärd tradition. ${ }^{9}$ Dit hör 'frågor och svar' genren (erotapokriseis) som var mycket omtyckt under antiken och medeltiden och som ofta fick formen av en dialog mellan en mästare och lärjunge. Vi möter den till exempel i Elucidarius. ${ }^{10}$ Den fornengelska dikten Salomon och Saturnus, som föreligger i flera versioner, är ett annat exempel på en tävlan i dialogform. ${ }^{11}$ Ädlingen Saturnus från kaldéernas land har farit världen runt för att inhämta visdom och hamnar till sist hos kung Salomo. De båda personerna försöker överträffa varandra i biblisk och allmän gåtkunskap. Epilogen omtalar att Salomo vann över Saturnus och tillrättavisade honom skarpt.

Den forniriska texten De två lärdes samtal ('The Colloquy of the Two Sages') utgör på sitt sätt en motsvarighet till Vafprúðnismál. Texten författades någon gång på 800- eller 900-talet och har formen av en dialog (immacaldam) mellan Néde, en ung poet (fili), och hans äldre kollega, Ferchertne. De frågor som ställs i den första delen av texten rör deras respektive färder, familjebakgrund, namn och yrke. Svaren ges i form av poetiska omskrivningar. Det är en uppvisning i kännedomen om poetiska synonymer, snarare än en tävlan i mytologisk kunskap. Den andra delen av De två lärdes samtal innehåller förutsägelser men även här kommer den rivaliserande aspekten i bakgrunden.

På Ferchertnes fråga om Néde har några förutsägelser att framföra (scéla) svarar Néde att han i sanning har goda förutsägelser att komma med. Så följer en kort profetia om en kommande lycklig tid. Néde ger en fråga tillbaka till Ferchertne: har $d u$ några förutsägelser att berätta om? På detta svarar denne med en lång profetia om de olyckor och onda ting som skall drabba Irland. De två lärdes samtal är en kristen kompilation men den har tagit upp element av gammal irisk tradition. Jämför man med den tävlan i kunskap om mytologi och gåtor som Vafprúðnismál och Hervarar-sagan företräder, framstår de två lärdes samtal som en mindre god parallell. Främst av det skälet att tävlingsmomentet spelar

\footnotetext{
${ }^{9}$ Så Sprenger 1985; Simek 2003; Simek \& Pálsson 2007.

${ }^{10}$ Holtsmark 1964 och 1975; se vidare om genren Volgers \& Zamagni 2003.

${ }^{11}$ Om denna text och dess versioner, se Anlezark 2009.
} 
en obetydlig roll och att det inte råder någon fiendskap mellan de två personerna.

\section{Den iranska myten om Axtya och Yōišta}

I sökandet efter paralleller till kompositionen av Vafbrúðnismál har jag sett närmare på den indo-iranska traditionen. Det visar sig att det finns motsvarigheter både i Iran och i Indien. Låt oss ta Iran först. I en av Avestas offerhymner ( $y a s ̌ t '$ 'erna) förekommer en anspelning på en tävlan i mytisk kunskap. Yašt 5 tillägnad gudinnan Anāhitā namnger en rad gestalter ur Irans mytiska historia vilka offrat till gudinnan, bland dem en person vid namn Yōišta. I stroferna 81 och 82 heter det:

till henne offrade Yōišta från Fryana-stammen, hundra hingstar, tusen oxar och tiotusen får på den vågomsvallade ön i floden Rangha. Sedan åkallade han henne: Ge mig denna ynnest, goda och mäktiga Ardvi Sura Anahita, att jag förmår övervinna den onde och illasinnade Axtya, genom att jag kan besvara de nittio-nio svåra och ondsinta frågor (frašna-) som denne onde och illasinnade Axtya skall ställa till mig. Ardvi Sura Anahita gav honom den ynnesten.

Yašten i Avesta lämnar oss ovetande om innehållet i frågorna och antyder inte heller den situation i vilken de två personerna möts. Lyckligtvis har en medeliransk version bevarat en berättelse som ger oss upplysning om både ramverket kring frågorna och vad de innehåller. Texten går under namnet Mādayān ì Yōšt $\bar{\imath}$ Friyān, 'Boken om Yōšt av Fryana-ätten' och är med stor sannolikhet redigerad under sassanidertiden, i runda tal mellan åren 250 och 600 . Här skildras omständigheterna kring tvekampen mellan den gode Yōšt och den onde Axt.

Den illvillige Axt uppenbarar sig med en härskara framför portarna till en ort som bär namnet 'Deras stad vilka uttolkar frågor' ( ̌̌ahr i frašn wizārānn). Axt hotar att döda invånarna och ödelägga staden om han inte får de rätta svaren på de frågor han kommer att ställa. Då träder Yōšt fram och erbjuder sig att besvara Axts frågor. Axt bjuder in Yōšt till sitt palats (dar) och bestämmer villkoren: ger Yōšt fel svar, kommer han att dödas. Axt ställer 33 frågor som huvudsakligen rör religionen och myterna. Med gudomlig hjälp lyckas Yōšt ge de rätta svaren, och han riktar i sin tur tre svåra frågor till Axt. Denne kan inte svaren men rusar till sin mästare, 
Ahriman, den Onde själv, för att få hjälp. Ahriman vägrar att avslöja svaren eftersom det skulle innebära slutet på den Ondes herravälde. Axt kommer tillbaka och medger att han är besegrad. Yošt framsäger en rituell formel som dödar Axt. Staden och dess invånare är nu räddade.

Den formelartade stilen och upprepningarna antyder att det ligger en poetisk tradition bakom den sassanidiska prosa-texten. Som exempel kan vi ta omkvädet som Yōšt reciterar varje gång han besvarar den illvillige Axts frågor:

må du ha det eländigt medan du lever, och falla ned i helvetet när du är död, du grymme och onde härskare.

Den medeliranska versionen av berättelsen återspeglar säkerligen den sassanidiska tidens miljö och litterära smak. Frågorna och svaren är kanske inte heller helt desamma som i den ursprungliga myten, den som yašten i Avesta anspelar på. Att själva ramverket återgår på gammal tradition är dock klart.

\section{Likheter mellan Iran och Skandinavien}

Trots skillnader föreligger klara överensstämmelser mellan de skandinaviska och iranska versionerna av den mytiska tvekampen. I båda fallen möter vi en gudom eller en gestalt som representerar gudomen, Oden i Vafprúðnismál och Yōišta och gudinnan Anāhitā i Iran. Gudomen eller dennas representant ger sig in i en tävlan som gäller mytisk kunskap, en tävlan som enligt reglerna är på liv och död. Motståndaren är en person som är fientligt inställd till gudar och människor, och det är han som börjar utfrågningen. Men initiativet tas sedan över av den goda sidan och sista frågan (eller frågorna) som ställs är omöjlig att besvara för den som inte har gudomlig kunskap. Den intellektuella tvekampen slutar i båda fallen på samma sätt: den förlorande parten mister livet.

Mycket i denna jämförelse går även att tillämpa på Hervarar-sagan och Gestumblindis gåtor. På en punkt blir jämförelsen till och med tydligare och det gäller den rituella aspekten. Gestumblindi offrar till Oden för att få hjälp inför mötet med kung Heidrek. Detta stämmer överens med situationen i den iranska myten där Yōišta frambär rikliga offer till Anāhitā för att få hennes stöd. 


\section{Den vediska traditionen}

Den kultiska kontexten framträder klarast i den fornindiska motsvarigheten till ramverket i Vafprúðnismál, den vediska rit som kallas brahmódya-, 'tävlan i rituell och mytisk kunskap', i Monier Williams sanskrit lexikon översatt med 'rivalry in sacred knowledge'. ${ }^{12}$ Taittirīya-Brāhmana $($ III $, 9,5)$ ger ett gott exempel på en brahmódya-rit. Den ingår som en viktig del av ritualen för det vediska hästoffret, aśvamedha-, och utförs av två präster. Den ene av dem, brahmán-prästen, identifieras med Bṛhaspáti, den särskilda offergudomen, och sitter på vänster sida, medan den andre adhvaryú-prästen som representerar guden Agni, sitter till höger. Det är han som ställer frågorna och brahmán-prästen som besvarar dem. Till exempel: "vilken var den Första Tanken?". Svaret blir: "den Första Tanken var i sanning Himlen, det är regnet". Ett annat exempel: "vem var den stora fågeln?" "Den stora fågeln var i sanning Hästen", lyder svaret från brahmán-prästen. Flera av frågorna och svaren är fortfarande dunkla för oss, men de måste förstås utifrån den världsbild som de vediska indierna hade. Syftet med brahmódya-riten är enligt Taittirīya-Brāhmaṇa att frammana den rätta sinnesstämningen inför det gudomliga (bráhman-), och skänka ära och glans åt den som står för offret.

\section{Några slutsatser}

Vissa drag som vi finner i de skandinaviska och iranska motsvarigheterna är mindre tydliga i den vediska brahmódya-riten. Så är fallet med det dystra öde som drabbar den förlorande parten; inte heller finns den skarpa motsättningen mellan en god och illvillig karaktär. Å andra sidan visar det vediska materialet att en ritualiserad tävlan i mytisk och rituell kunskap utgjorde ett viktigt moment av offerritualet. Förmodligen var detta också fallet med den iranska traditionen, exemplifierad av mötet mellan Yōišta och Axtya. Huruvida det förekom någon slags rivaliserande uppvisning i mytisk och rituell kunskap som en del av skandinaviska offerkult, undandrar sig vårt bedömande. Däremot vill jag hävda att den indo-iranska traditionen ger de bästa parallellerna till Vafprúðnismáls

\footnotetext{
${ }^{12}$ Jfr. West 2010: 73-74 som uppmärksammar parallellen till Vafprúdnismál, dock utan att göra en närmare analys.
} 
ramberättelse. Man kan dra några slutsatser av detta. För det första, ett medeltida kristet inflytande ter sig inte särskilt troligt. För det andra, den genre som ramen kring Vafprúðnismál representerar går tillbaka på förkristen skandinavisk tradition, och man kan på goda grunder även våga påståendet att den har indoeuropeiska rötter.

\section{Bibliografi}

\section{Källor}

Eddukvæðð I, Goðakvææði. Jónas Kristjánsson og Vésteinn Ólason gáfu út. Reykjavík 2014.

Hervarar Saga ok Heiðreks, with notes and glossary by G. Turville-Petre. Introduction by Christopher Tolkien. London 1956 (reprinted 1976 with minor corrections and additional bibliography). London.

Kommentar zu den Liedern der Edda / Band 1/I+II: Götterlieder, Teil I: Voluspá [R], Hávamál / Teil II: Vafprúðnismál, Grímnismál, Voluspá [H], Zwergenverzeichnis aus der Gylfaginning. Hrsg. Klaus von See, Beatrice La Farge, Katja Schulz. Heidelberg 2019.

Vafprúðnismál. Edited with an introduction and notes by Tim William Machan. 2nd ed. Durham 2008.

\section{Litteratur}

Anlezark, Daniel, 2009: The Old English Dialogues of Solomon and Saturn (Anglo-Saxon Texts 7). Cambridge.

Ejder, Bertil, 1960: 'Eddadikten Vafprúonismál'. Vetenskapssocietetens $i$ Lund Årsbok, s. 3-20.

Finlay, Alison, 2011: 'Risking One's Head: Vafprúðnismál and the Mythic Power of Poetry.' Myths, Legends and Heroes. Essays on Old Norse and Old English Literature in Honour of John McKinnell, ed. by Daniel Anlezark. Toronto, s. 91-108.

Edlund, Lars Erik, 2013: 'Eldtände, fagerkvist och spö. Jättars, alvers och vaners språk i Eddadikten Allvismål'. Morfars karta visar vägen. Ett urval språkvetenskapliga texter 1979-2013 av Lars-Erik Edlund, red. Roger Jacobsson. Umeå, s. 302-320.

Gísli Sigurðsson, 2006: 'Vafprúðnismál'. Reallexikon der Germanischen Altertumskunde 32: 27-30.

Holtsmark, Anne, 1964: 'Den uløslige gåten. Maal og Minde', s. 101-105.

Holtsmark, Anne, 1975: 'Vafprúðnismál'. KLNM 19: 422-423.

Hultgård,Anders, 2009: 'The wisdom contest in Vafprúđnismál'. Analecta septen- 
trionalia. Beiträge zur nordgermanischen Kultur- und Literaturgeschichte. Berlin/New York, s. 531-539.

Hultgård, Anders, 2017: Midgård brinner. Ragnarök $i$ religionshistorisk belysning. Uppsala.

Jónas Kristjánsson og Vésteinn Ólason, 2014: se Källor, Eddukvæði.

Kragerud, Alf, 1981: 'De mytologiske spørsmål i Fåvnesmål'. Arkiv för Nordisk Filologi 96: 9-48.

Kuusela, Tommy, 2017:"Hallen var lyst $i$ helig frid". Krig och fred mellan gudar och jättar $i$ en fornnordisk hallmiljö. Stockholm.

Machan, Tim W., 2008: se Källor, Vafprúðnismál.

McKinnell, John, 1994: Both One and Many. Essays on Change and Variety in Late Norse Heathenism. Roma.

Simek, Rudolf, 2003: Religion und Mythologie der Germanen. Darmstadt.

Simek, Rudolf \& Hermann Pálsson, 2007: Lexikon der altnordischen Literatur. 2. Aufl. Stuttgart.

Sprenger, Ulrike, 1985: 'Vafprúđnismál 10,3: Der Kaltgerippte'. Arbeiten zur Skandinavistik 6, hrsg. von H. Beck. Frankfurt am Main, s. 185-210.

Volgers, Annelie \& Claudio Zamagni (eds.), 2003: Erotapokriseis: Early Christian Question-and-Answer Literature in Context: Proceedings of the Utrecht Colloquium, 13-14 October 2003. Leuven.

de Vries, Jan 1934: 'Om Eddaens Visdomsdigtning'. Arkiv för Nordisk Filologi 50: $1-59$.

West, Martin L., 2007: Indo-European Poetry and Myth. Oxford.

\section{Summary}

Vafprúðnismál is composed as a wisdom contest between a god and a giant. The genre itself has parallells elsewhere. Medieval literature often used the dialogue form to convey knowledge on religious matters. An influence on the eddic poem from Christian texts has been argued. Closer correspondances are found in the Indo-Iranian tradition, however. The author concludes that the framework of Vafprúðnismál represents an ancient genre with roots in the Indo-European past.

Keywords: Vafprúđnismál, Poetic Edda, wisdom contest, Scandinavian mythology, Odin, Avesta, Anāhitā, Veda, horse sacrifice, brahmódya-.

Anders Hultgård

Uppsala universitet

Teologiska institutionen

Anders.Hultgard@teol.uu.se 


\title{
Færeyinga saga som historisk kilde. En vurdering af sagaens ophavssituation og politiske miljø
}

\author{
ANDRAS MORTENSEN
}

\section{Indledning}

Inden for sagaforskningen bliver Jómsvíkinga saga, Orkneyinga saga og Færeyinga saga grupperet som en type af sagaer, der er en mellemting mellem kongesagaerne og Islændingesagaerne, dels på grund af deres tematik og dels på grund af deres alder. Melissa Berman gav dem arbejdsbetegnelsen politiske sagaer, fordi de handler om magtkampe i små nordbosamfund, som mister deres frihed (Berman 1985). De repræsenterer efter hendes opfattelse en særlig teknik hos de tidlige islandske forfattere at undersøge historiske processer ved at fokusere på en symbolsk og dramatisk konflikt, tilsyneladende motiveret af et behov for at formulere indlæg i den hjemlige debat om islændingenes egen frihed, som i første del af det 13. århundrede var under pres på grund af det norske kongedømmes ekspansive politik. Også Peter Foote så en forbindelse mellem de tre sagaer i deres kristne tema og påpegede ligheder i deres fortælleteknik (Foote 1988), og ligeledes Judith Jesch, som dog først og fremmest så en forbindelse $\mathrm{i}$ deres fælles alder, komplicerede teksthistorie og fragmentariske overlevering (Jesch 1993). I denne artikel vil jeg koncentrere mig om Færeyinga saga, som er den eneste overleverede beretning om færingerne i vikingetiden. Den beretter underholdende om

Mortensen, Andras. 2019. Færeyinga saga som historisk kilde: En vurdering af sagaens ophavssituation og politiske miljø. Scripta Islandica 70: 18-36. 
magtudviklingen i tiden fra ca. 960 til ca. 1040 og de indbyrdes forhold mellem to høvdingeslægter, Hofs-slægten og Gọtuskeggja-slægten, som rådede over hver sin halvdel af Færøerne. Forfatteren fortæller, at disse magtstillinger havde de i len af norske overherrer, først Haraldr gráfeldr og Hákon jarl, siden Óláfr Tryggvason og et kvart århundrede senere, da de to slægter blev forenet med ægteskab, af Óláfr helgi og hans søn, Magnús góði. Nogle af høvdingerne bliver også nævnt som overherrernes sysselmænd, der indkrævede skat af øboerne.

Spørgsmålet, som stilles i denne artikel, er, hvordan Færeyinga saga skal forstås som historisk kilde, og spørgsmålet har sin særlige årsag. Der er nemlig stor sandsynlighed for, at skatlandsberetningen, som danner grundtemaet i sagaen, i hvert fald delvis, er usand. Inden for historieforskningen er det blevet påpeget, at grundlaget for den beskrevne form for overhøjhedsudøvelse, i særdeleshed med inddrivelse af skat under ledelse af sysselmænd, ikke blev dannet før senere, nemlig i forbindelse med den norske statsdannelsesproces i borgerkrigstiden, der startede med kong Sigurðr Jórsalafaris død i 1130. Starten på kongedømmets ekspansive politik mod øerne i vest tidsfæstes af historieforskningen til 1098, da kong Magnús berfottr indgik aftale med kong Edgar af Skotland om, at Orknøerne og Suderøerne skulle være under norsk overhøjhed (Helle 2005; jfr. Wærdahl 2011: 58 ff.). Derudover er det inden for sagaforskningen blevet påpeget, at skatlandsberetningen bygger på en litterær konstruktion, som forfatteren lavede. Ólafur Halldórsson kunne i sine tekststudier påvise, at historien, som begrunder lensforholdet og skattebetalingen, er tekstafhængig af en lignende historie i Orkneyinga saga, som blev skrevet før Færeyinga saga, og sandsynligvis konstrueret med denne historie som grundlag (Ólafur Halldórsson 1987: 167-168).

Spørgsmålet om, hvordan Færeyinga saga skal forstås som historisk kilde, hænger sammen med spørgsmålene om, hvornår og hvorfor sagaen blev skrevet, dvs. sagaens ophavssituation. Som nævnt mente Berman, at skrivningen var motiveret af debatten om det norske konged $\varnothing$ mmes ekspansive politik i forhold til Island på nedskrivningstidspunktet. Dette var også et synspunkt, som Ólafur Halldórsson havde, dog med en tilføjelse om, at der også forelå et underholdningsmotiv (Ólafur Halldórsson 2006: 9-10). Jesch fremholdt et lignende synspunkt og mener, at Færeyinga saga alene blev skrevet med et underholdningsmotiv for $\varnothing j e$, og at sagaen er et eksempel på historisk fiktion, hvor pålideligheden i udsagnene om forholdene i tiden, der omtales, er tvivlsom (Jesch 1993). I lyset af, at grundtemaet, som angår de politiske forhold mellem Færøerne 
og Norge, bygger på en litterær konstruktion, går jeg i denne artikel ud fra, at Færeyinga saga først og fremmest var politisk motiveret, hvilket også kan spores i, at forfatteren i sagaens afslutningskapitel pointerer, at samtidens sysselmænd på Færøerne i direkte linje stammede fra sagatidens forenede høvdingeslægt (jfr. Mortensen 2005). Med til vurderingen af sagaens udsagn hører også, at udsagnene kan forudsætte en forventningsafstemmelse mellem en opdragsgiver og forfatteren, samtidig som fortællingen var underlagt kontrol og konsensus i det kollektive memoria, således som Ólafía Einarsdóttir påpegede i forbindelse med samtidssagaerne (Ólafía Einarsdóttir 1995). Hovedspørgsmålet, som stilles i denne artikel, er derfor, hvilke slutninger man ud fra det, som den litteraturhistoriske forskning om Færeyinga sagas overlevering og tekstuelle afhængighedsforhold er kommet frem til, kan drage om sagaens ophav og de politiske faktorer, der gjorde sig gældende i forbindelse med dannelsen af sagaens udsagn og form.

\section{Overlevering og datering}

Færeyinga saga findes overleveret spredt i to kompilationsværker, nemlig den Store saga om Óláfr Tryggvason fra ca. 1300 og Flateyjarbók fra tiden omkring 1390. Overleveringen i Flateyjarbók menes at være den mest oprindelige, mens overleveringen i den Store saga om Óláfr Tryggvason er forkortet og omtaler ikke tiden efter denne konge. I de overleverede beretninger findes flere tegn på, at disse beretninger oprindelig har tilhørt en samlet saga om færingerne.

De fleste forskere i dag er enige om, at den oprindelige Færeyinga saga blev skrevet inden for de to første årtier af det 13. århundrede. Denne datering bygger på Finnur Jónssons og Ólafur Halldórssons vurderinger fra henholdsvis 1927 og 1987. Finnur Jónsson anførte, at sagaen må være skrevet efter 1200, eftersom forfatteren ser ud til at have anvendt en tidlig version af Orkneyinga saga, skrevet omkring 1200, som forlæg, men før Snorri Sturluson skrev sin særskilte saga om Óláfr helgi i midten af 1220erne, og muligvis også før 1218/19, da munken Gunnlaugr Leifsson i klosteret på Pingeyri døde, eftersom begge disse forfattere ser ud til at have anvendt en sagaberetning om færingerne som forlæg i deres forfatterskaber og Snorri Sturluson nævner, at hans beretning om færingerne kun var en del af en større beretning. Til støtte for dette anfører Ólafur Hall- 
dórsson, at Einarr sysselmand, som i den overleverede sagas afslutningskapitel omtales som forfatterens samtidige, også omtales i en af Baglersagaerne som ejer af et skib, der i 1210 førte kong Sverrirs påståede søn, Erlingr, fra Færøerne til Norge (Ólafur Halldórsson 1987: 210-211). Ólafur Halldórsson påpegede yderligere tre forhold til støtte for, at sagaen blev skrevet i det nævnte tidsrum. Det første var, at en hjemmelsmand, som forfatteren nævner som Hallbjorn hali hinn fyrri, sandsynligvis er identisk med den Hallbjorn hali, som i Skáldatal omtales som digter ved hofferne hos den svenske kong Knútr Eiríksson (d. 1196) og den norske kong Sverrir (d. 1202). Det andet var, at forfatteren synes at have været så velkendt med folkeliv og hændelser i Eyjafjorðr på Nordlandet i Island i 1190-erne, som er beskrevet i Guðmundar saga dýra, at han må have haft sin hjemstavn der. Og det tredje var, at det er sandsynligt, at oplysningen, som Fagrskinna, som er fra ca. 1220 og ældre end Snorris særskilte saga om Óláfr helgi, giver om, at Færøerne var blandt de lande, som Óláfr helgi havde beskattet, stammede fra Styrmir Kárason, som muligvis havde den fra Færeyinga saga (Ólafur Halldórsson 1987: 232-239).

På et afgørende punkt var Ólafur Halldórsson uenig med Finnur Jónsson, nemlig om dateringen af den overleverede teksts første del, som svarer til kapitlerne 1-33 i den rekonstruerede Færeyinga saga. Jónsson gjorde opmærksom på, at der er forskel på, hvordan sagahelten Sigmundr Brestisson fremtræder i første og anden del. Finnur Jónsson kom derfor frem til, at første del af sagaen er stærkt udvidet og bearbejdet, og at denne bearbejdelse er sket omkring 1300 (Finnur Jónsson 1927: 9). Ólafur Halldórsson kom i sine studier frem til, at der ikke er grundlag for denne antagelse, eftersom der er stor sandsynlighed for, at der før 1200 fandtes skriftlige forlæg for de tekstafsnit, som Finnur Jónsson mente var interpoleret i sagaen omkring 1300 (Ólafur Halldórsson 1987: 37-54). På dette grundlag kom Ólafur Halldórsson frem til, at teksten i Flateyjarbók, som i den rekonstruerede Færeyinga saga svarer til kap. 1-27, 34-42 og 49-59, stammer fra et tabt håndskrift, som kompilatoren af Flateyjarbók havde til rådighed, hvor sagaen fandtes samlet, mens teksten i Flateyjarbók, som svarer til den rekonstruerede sagas kap. 28-33, stammer fra et håndskrift med den Store saga om Óláfr Tryggvason fra ca. 1300, og kap. 43 og 45-48 fra et håndskrift med Snorris særskilte saga om Óláfr helgi fra 1220 -erne.

Den tidlige datering af den oprindelige saga er blevet anfægtet af Helgi Guðmundsson, som kom med en teori om, at sagaen blev skrevet af Sturla Pórðarson om vinteren 1277-78, mens han opholdt sig på Færøerne 
på grund af et skibsforlis (Helgi Guðmundsson 2002: 13-27). Hovedargumentet for denne slutning er, at sagaen må være yngre end 1255, hvilket Helgi Guðmundsson begrunder med, at navnebroderen til førnævnte hjemmelsmand, Hallbjorn hali hin fyrri, nemlig Hallbjorn hali Jónsson, var ukendt for islændinge før han i 1255 blev kendt som en af dem, der dræbte høvdingen Oddr Pórarinsson i slaget i Geldingaholt i Skagafjorðr, som er dokumenteret i Sturlunga saga. Argumentationen går således på, at forfatteren må have skrevet efter 1255, hvis den senere Hallbjorn hali blev berømt dette år. Helgi Guðmundsson mener ikke, at omtalen hos Snorri Sturluson allerede i 1220-erne, som med udsagnet om, at der findes "stórar frásagnir" om det videre forløb af Óláfr helgis mislykkede beskatningsfors $\emptyset \mathrm{g}$ af færingerne, som Snorri ikke omtaler, er noget bevis for, at der fandtes en skrevet Færeyinga saga før Snorri. Dette begrunder han med, at Snorri ikke nævner sit forlæg ved navn således som han ellers gjorde, når han anvendte Orkneyinga saga som kilde. De øvrige argumenter, som Finnur Jónsson og Ólafur Halldórsson nævner for sagaens datering til de første årtier af det 13. århundrede, tager Helgi Guðmundsson ikke stilling til. Senere vil jeg argumentere for, hvorfor Finnur Jónssons og Ólafur Halldórssons dateringer til de første årtier af det 13. århundrede efter min mening er mere sandsynlige end Helgi Guðmundssons datering til vinteren 1277-78.

\section{Sagaens tendens}

Ud over dateringen har beretningens tendens betydning, når målet er at drage slutninger om ophavssituationen. I Færeyinga saga viser tendensen sig på flere måder, og mest konkret i beskrivelsen af de politiske relationer mellem færingerne og de norske magthavere. Men den kan også ses på anden vis.

Peter Foote påpegede, at selv om forfatteren med stor sandsynlighed var islænding, så ser beretningen i Færeyinga saga ud til at være indpakket i en lovforståelse, som i højere grad er norsk end islandsk (Foote 1970). Forfatteren ser ud til at have haft et indgående kendskab til Gulatingsloven, mens hans kendskab til islandsk lovgivning heller ikke fornægter sig. Disse forhold så Foote som udtryk for, at den islandske forfatter bevidst har villet minde sit islandske publikum om, at det retslige miljø, som han berettede om, ikke var det hjemlige, men at historien foregik i 
fremmede omgivelser. Blandt andet beretter han om et grvarping, som blev afholdt på Hernar i Hordaland ved indsejlingen til Bergen, og dette begreb forekommer ikke i islandsk terminologi før i Jónsbók fra 1281, og ligeledes om óbótamenn, útlegð og sekð i norsk lovforståelse, og også landbúi i den norske forståelse af en jordlejer, samt lodkastning i forbindelse med arveskifte, alt i henhold til terminologien i Gulatingsloven. Foote kom i sin analyse frem til, at forfatteren ikke bare vidste noget, men en hel del om norske lovforhold, og fremførte, at dette er en kendsgerning, som bør tages med i betragtning i enhver diskussion om forfatterens identitet eller miljø.

Tendensen viser sig også i verdensbilledet, som kommer til udtryk. I Færeyinga saga kommer det frem i det mytologiske mønster, som ser ud til at understøtte teksten, og ses i den særlige fortælleteknik, som karakteriserer sagaen. Fortælleteknikken viser en forfatter, som med uudtalte insinuationer spiller op til læserens fantasi. Især anvendes denne teknik i forbindelse med beskrivelsen af den antagonistiske sagafigur, den hedenske Prándr í Gọtu, og Ólafur Halldórsson påpegede, at i historien om drabet på Óláfr helgis skatteopkræver har den fremmede mand, som viste sig på tinget, barfodet og iklædt bred hat, grøn kappe og linbukser på benene med et "refði" i hånden, og som læseren slutter må være Prándr, en vis lighed med Odin, således som denne er kendt fra Volsunga saga (Ólafur Halldórsson 1987: 174). I historien, som er overleveret hos Snorri, efter overleveringen at dømme med en større beretning som forlæg, bliver skatteopkræveren hugget ned af drabsmændene, som var Prándrs fostersønner, med en $\varnothing \mathrm{kse}$ og dræbt med et dødbringende slag med genstanden, som den fremmede havde medbragt og som i sagaen benævnes "refði". Navnet på dette redskab tolkede Ólafur Halldórsson som et scepter, dvs. magtsymbolet, som blev båret af konger. At historien ikke er Snorris værk, men stammer fra den oprindelige saga, ses af, at den samme fortælleteknik anvendes i sagaens indledende kapitler om, hvordan Prándr med list vandt sin rigdom på markedet i Haløre.

Samme type verdensbillede ser ud til at følge hovedpersonen Sigmundr Brestisson. Gro Steinsland har påpeget, at forfatteren i sin skabelse af ham som overgangsfigur mellem det hedenske og det kristne har anvendt mytologiske elementer, som også er kendt fra Háleygjatal og Grímnismál og har forbindelse med før-kristen ideologi omkring herredømme eller kongedømme (Steinsland 2005; jfr. 2011). Disse elementer, som ligeledes er knyttet til forestillinger om Odin og angår indvielse af en ny hersker, prøvelser, som han må gennemgå, erotiske alliancer, overførsel af viden 
og avling af et særligt barn, ses i særdeleshed i historien om Sigmundrs ophold i sin ungdom hos Hákon jarl, hvor hans skæbne som fremtidig høvding i kristendommens tjeneste bestemmes af indvielsen med guldringen, som han modtager af Hákon jarls åndelige følger, Porgerðr Horðabrúðr. Steinsland argumenterer for, at disse mytologiske elementer ikke bør anses som et overfladisk litterært element, men udg $\varnothing \mathrm{r}$ med sin dannelse af et strukturelt mønster gennem hele sagaen en ideologisk forestilling om herskerskab, som er med til at udvide vores forståelse af sagaen som værk og de mål og perspektiver, som forfatteren havde. Et lignende budskab med associationer til Odin ser hun i navnene Hrafn og Úlfr, som begge spiller vigtige roller i fætrene Sigmundrs og Pórirs prøvelser, samt i angivelsen af sagahelten Sigmundrs alder med ni-tallet som grundlag. Han var ni år gammel, og hans fætter og ligestillede til retten til høvdingedømmet, Pórir, elleve, da Prándr solgte dem som trælle, atten år gammel, og Pórir tyve, da deres ophold hos den fredløse Úlfr sluttede, og syvogtyve, da han efter tjeneste hos Hákon jarl overtog sit høvdingedømme på Færøerne. Steinsland viser, at forfatteren, med tallene ni og elleve, associerer med fortællingen om de to kongelige brødre, Agnarr og Geirroððr, som henholdsvis som elleve og ni årige bliver opfostret hos Odin og Frigg i forklædning, og at digtet med tallene refererer til ultimogenitur, hvor den yngste foretrækkes som den næste hersker. Fortællingen om brødrenes prøvelser i de norske skove er således om overførsel af visdom fra Odin til den yngste af de to som fremtidig hersker. Steinsland argumenterer for, at ni år for forfatteren ser ud til at være et meningsfuldt interval for overgangen mellem de vigtige ændringer i en herskers liv, og både i Grímnismál og Færeyinga saga bliver herskerskabet til slut overtaget af den yngste og ikke den førstefødte.

I tillæg til dette fremførte Richard North, at den grønne farve på den fremmedes kappe på tinget, hvor Óláfr helgis skatteopkræver blev dræbt, kan opfattes som farven på den kapital, som Prándr tilsigtede, nemlig de smukke og om sommeren højgrønne Færøer med enge, indmarker og udmarker, hvilket han forbinder med fortsættelsen af beretningen om kuppet på tinget, hvor Prándr optræder som ægteskabsmægler mellem de to gamle høvdingeslægter, som siden blev forenet i kristent ægteskab mellem Prándrs fostersøn, Leifr Qzurarson og Póra Sigmundardóttir (North 2005). Efter ægteskabet arver de landejendommene, som havde tilhørt Prándr og de to høvdingeslægters arvtagere, og læseren får en opfattelse af, at Prándr med dette sikrede en arvefølge til den færøske odel. North stiller derfor spørgsmålet, hvorfor det var så magt- 
påliggende for den islandske forfatter at konstruere denne beretning og forbindelsen mellem de færøske høvdinger og de norske herskere i tiden frem til Magnús góðis kongetid? Han foreslår, at det muligvis har forbindelse med kampen om den kongeideologi, som kong Sverrir stod for og som blev videreført af hans efterkommere i første del af det 13. århundrede. Han gjorde opmærksom på, at ideologien, som kommer til syne i beretningen om Prándrs planer om et færøsk dynasti, var baseret på den samme retslige fiktion, som kommer til syne hos Snorri om, at landskongedømmet var kongeættens odel.

\section{Det litterære miljø}

Set fra en historisk synsvinkel tyder herskerideologien, som kommer til syne, på, at den overleverede beretning genspejler en tid, hvor den romerske rex iustus ideologi endnu ikke var fuldt gennemført i legitimeringen af kongemagten. I henhold til Sverre Bagges undersøgelser af ideologi i Sverris saga i forhold til Hákonar saga skete denne gennemførelse i løbet af Hákon Hákonarsons kongedømme i forbindelse med hans kroning i 1247 (Bagge 1996; jfr. diskussionen mellem Ljungqvist 2006; Lönnroth 2006; Bagge 2007). Herskerideologien i Færeyinga saga kan derfor henføres til tiden før midten af det 13. århundrede, og dette taler imod Helgi Guðmundssons datering af beretningen til vinteren 1277-78. I forhold til, at det ser ud til, at forfatteren har villet vise, at Færøerne havde været under norsk overherredømme i længere tid end de i virkeligheden havde, og at der var en politisk hensigt med påpegningen af, at samtidens sysselmænd tilhørte den gamle høvdingeslægt, nemlig at sysselmandsstyret i forfatterens samtid havde historisk begrundelse, så havde Færøerne i 1277-78 allerede været norsk skatland og haft en sysselmand i mere end 100 år, hvis vi bedømmer ud fra omtalen af skatlandene i Historia Norwegie fra tiden 1160-75 og første kapitel i Sverris saga, af hvilke det fremgår, at Færøerne var under norsk centralstyre i Magnús Erlingssons kongetid (1156-1184). Derimod tyder pointeringen af, at sysselmændene i samtiden tilhørte den gamle høvdingeslægt, på, at der for kort tid siden var sket en ændring af skatlandsstyrelsen, som det var værd at gøre opmærksom på.

Som argument for dette kan anføres, at en sådan ændring fandt sted i de norske landsdele under kong Sverrir og på Shetlandsøerne som en straffe- 
foranstaltning imod Orknøjarlen efter øskeggeopstanden i 1194, da kong Sverrir sendte norske sysselmænd ud til Shetlandsøerne til at forvalte de overvundne stormænds ejendomme (jfr. Sverris saga (Flateyjarbók), kap. 106). I færøsk sammenhæng viser ændringen sig i oplysningen i afslutningskapitlet i Færeyinga saga om, at sysselmændene på Færøerne $\mathrm{i}$ begyndelsen af det 13. århundrede var beslægtede med den gamle høvdingeslægt, når den sammenholdes med historien i første kapitel i Sverris saga om, at sysselmanden før Sverrirs afrejse fra Færøerne i 1175, var udsendt fra Norge. Dermed fås en opfattelse af, at der i tiden imellem 1175 og ca. 1210 var sket en ændring i sysselmandsinstitutionens grundlag i færøsk sammenhæng.

Sammen med den sandsynlige datering af den oprindelige saga til engang i tiden mellem 1200 og 1220, giver herskerideologien et afsæt til en vurdering af ophavssituationen. Ólafur Halldórsson kom i sine undersøgelser frem til, at Færeyinga saga sandsynligvis er skrevet af en mand, som havde hjemstavn i Eyjafjorðr i Nordisland. Hans vurderinger af tekstens afhængighed åbner imidlertid også op for en præciserende tolkning af, hvor i Nordisland sagaen blev skrevet. For det første tyder antagelsen om, at Gunnlaugr Leifsson i Pingeyrarklosteret anvendte en oprindelig Færeyinga saga som kilde på, at den oprindelige sagatekst befandt sig i Pingeyrarklosterets bibliotek før Gunnlaugrs død i 1218/19. Denne antagelse underst $\varnothing$ ttes for det første af, at der også i to andre Pingeyrarhistorikeres værker fra samme tid ser ud til at kunne spores forbindelser til Færeyinga saga, nemlig mellem denne saga og henholdsvis Oddr Snorrasons saga om Óláfr Tryggvason og Styrmir Kárasons saga om Óláfr helgi. Forbindelsen til Oddr Snorrasons værk kan spores i den heroiserende omtale af kong Óláfr Tryggvason og måden at beskrive de to sagahelte, henholdsvis Kjartan Ólafsson i Oddrs saga om Óláfr Tryggvason og Sigmundr Brestisson i Færeyinga saga, som kongens jævnbyrdige i svømmeidræt (jfr. Heller 1998). Oddr skrev ca. 1190, og det tyder på, at forfatteren af Færeyinga saga, som skrev kort efter 1200, har hentet inspiration i hans værk og derfor, at han tilhørte det samme litterære miljø. Forbindelsen mellem Færeyinga saga og Styrmirs saga om Óláfr helgi er mindre klar, men som nævnt anså Ólafur Halldórsson det som sandsynligt, at Snorri Sturlusons beretning om færingerne stammede fra Styrmir, som havde den fra Færeyinga saga (Ólafur Halldórsson 1987: 232-233). Nogle forskere mener, at Styrmir Kárason havde fået sin opdragelse i klosteret på Pingeyri, og at han muligvis medvirkede ved forfattelsen af Sverris saga, den mest berømte saga fra dette kloster (Ólafía Einars- 
dóttir 1964: 239). I hvert fald viser prologen til Sverris saga i Flateyjarbók, at det var hans afskrift af Sverris saga, som lå til grund for teksten i Flateyjarbók. For det andet tyder Ólafur Halldórssons undersøgelser af Færeyinga sagas skriftlige forlæg på, at forfatteren havde adgang til det skriftlige kildemateriale, som det litterære miljø i Pingeyrarklosteret også havde til rådighed. Blandt andet ser han ud til at have haft adgang til Aris arbejder og en Jómsvíkingasaga, som også Oddr Snorrason havde adgang til, og endvidere Orkneyinga saga, som han tydeligvis har anvendt som inspiration til sine beskrivelser flere steder, blandt andet i forbindelse med beskrivelsen af de færøske høvdingers lensforhold til norske overherrer (Ólafur Halldórsson 1987: 166-194; jfr. Finnur Jónsson 1927: 30-31). Eftersom hovedparten af materialet i Flateyjarbók ser ud til at bygge på skrifter fra klosterbiblioteket i Pingeyri, som befandt sig mindre end tre timers ridt fra gården Víðidalstunga, hvor Flateyjarbók blev fremstillet i slutningen af det 14. århundrede, giver det for det tredje støtte til antagelsen om, at Færeyinga saga har forbindelse til dette klosters litterære miljø (jfr. Ólafía Einarsdóttir 2001).

To forhold i den overleverede tekst underst $\varnothing t t e r$ denne antagelse. Det ene forhold er, at der i talen, som Óláfr Tryggvason i den rekonstruerede sagas kapitel 29 holder for Sigmundr Brestisson, hvor kongen sammenligner deres skæbner, forekommer en retorisk ordsammenstilling, som giver indtryk af, at han, som skrev talen, anvendte de samme retoriske virkemidler og udtrykte sig med de samme ord, som ham, der skrev talerne i Sverris saga. I talen forekommer nemlig en tautologisk konjunktion, dvs. hvor to eller flere nærbeslægtede ord forbindes for at give en retorisk virkning, og ordsammensætningen er "valk ok vandræði", som kan oversættes til modgang og elendighed (jfr. Fær. kap. A29.11-12). Hallvard Lie påpegede, at den tautologiske konjunktion er et retorisk virkemiddel, som ofte forekommer i talerne i Sverris saga, og at netop ordene, "válk" og "vandræði" eller "vandkvæði", kan karakteriseres som yndlingsord i kong Sverrirs taler (Lie 1937: 107-109). At netop disse yndlingsord forekommer i Óláfr Tryggvasons tale i Færeyinga saga tyder derfor på, at talerne i Sverris saga og Færeyinga saga er beslægtede og tilhører det samme litterære miljø, og muligvis den samme forfatter. Dette sandsynlige afhængighedsforhold undgik Finnur Jónsons opmærksomhed, da han, med udgangspunkt i Óláfr Tryggvasons andre taler i den Store saga om Óláfr Tryggvason fra ca. 1300, vurderede den som en senere interpolation, hvilket var et synspunkt, som Ólafur Halldórsson valgte at følge, selv om hans studier af tekstens afhængighed pegede i en anden retning, nemlig at 
sagaens første del ikke var resultatet af en interpolation fra ca. 1300, men stammede fra den oprindelige saga (jfr. Ólafur Halldórsson 1987: 13-18). Det andet forhold er, at forfatteren i sin redegørelse i den rekonstruerede sagas kapitel 54 af de færøske høvdingedømmers forening også anvender et andet litterært virkemiddel, som er karakteristisk for Sverris saga, nemlig anvendelse af drømme som varsel. Lars Lönnroth påpegede, at det karakteristiske med drømmene i Sverris saga i forhold til drømme i andre sagaer er, at de ikke varsler frygtelige ulykker, men præsenterer symbolske og mystificerende budskaber, som varsler kong Sverrirs kommende sejre som konge (Lönnroth 2006). I Færeyinga saga er det Puríðr, enken efter sagahelten Sigmundr, som drømmer, at hendes afdøde mand viste sig og sagde: "pat er sem per synizst at ek er her komínn ok er mer petta lofath af gude sealfum segir hann en haf æigi hardan hug ne illan a L(eifi) magi pinum puiat honum mun audit verda at reka yduarra skamma" (Fær., kap. F54.17-23). Drømmen, som indeholder et ideologisk budskab om fremtidens færøske høvdingedømme i kristendommens navn, har således et karaktertræk, som ligner det, der adskiller drømmene i Sverris saga fra drømme $i$ andre sagaer.

\section{Forfatter og hjemmelsmand}

Et af særtrækkene i Færeyinga saga er, at forfatteren ikke anvender skjaldekvad som kildemateriale. På den anden side er det tydeligt, at forfatteren benytter sig af mundtlige informationer, hvilket er et træk, som er med til at placere sagaen i den tidlige islandske sagatradition. Finnur Jónsson kom frem til, at sagaen bærer præg af en ret pålidelig mundtlig fortælling (Finnur Jónsson 1927: 14), og Ólafur Halldórsson, som var enig, udvidede opfattelsen med, at forfatteren havde en færøsk hjemmelsmand (Ólafur Halldórsson 1987: 197). Dette begrunder han med, at det i sagaen er tydeligt, at forfatteren ikke selv havde kendskab til den færøske natur, men baserede sin beretning på det, som var fortalt ham, og at fortælleren havde større viden om steder og forhold på Færøerne end man kan forvente af en, som aldrig har været på Færøerne. Derudover påpegede han, at sagaen flere steder har oplysninger om familieforhold på Færøerne, som er løsrevne fra handlingsgangen i beretningen, og tolker dette som udtryk for, at forfatteren refererer en fortæller, der havde indgående kendskab til de færøske slægter (Ólafur Halldórsson 1987: 208). I tilslutning til Footes 
konklusion om forfatterens kyndighed med norske love påpeger Ólafur Halldórsson derudover, at de historier, hvor det norske lovsprog findes, ser ud til at være baseret på sagn fra Færøerne, og derfor, at lovsproget har færøsk oprindelse, og at lovkundskaben også kunne stamme fra hjemmelsmandens rejser i Norge. Dette mener han finder støtte i, at det i sagateksten er tydeligt, at hjemmelsmanden havde indgående kendskab til lokale forhold og stednavne i Norge og derfor må have opholdt sig der under rejser, både Østenfjelds og i vest. Som eksempler fremdrager Ólafur Halldórsson formuleringer i forbindelse med stednavne som "austr við Túnsberg", "Ganga nú ór Víkinni til Upplanda ok pann veg austan um Heiðmork ok norðr til Dofrafjalls”, og “... ok fylgir peim um Dofrafjall, par til er peir sjá norðr af til Orkadals" (Ólafur Halldórsson 1987: 218-219), der alle tyder på lokalkendskab. I forlængelse af dette kommer Ólafur Halldórsson også ind på den anakronistiske omtale af markedet på Haløre i sagaens 2. kapitel og fremfører, at det er tydeligt, at forfatteren ikke har oplevet dette marked ved selvsyn, men baserer sin viden om dette på samtidige fortællinger fra berejste hjemmelsmænd om markedet i Skanør, som opstod i forbindelse med sildefiskeri i Øresund i slutningen af det 12. århundrede, eller på tilgængelige tekster i sin samtid, muligvis Sverris saga, som også nævner markedet på Haløre (Ólafur Halldórsson 1987: 210-212).

Med hensyn til sagaens ophavssituation tyder alt dette på, at Færeyinga saga er produktet af et tæt forhold mellem forfatteren og en berejst hjemmelsmand, hvor det var hjemmelsmanden, og ikke forfatteren, som formidlede lovforhold og slægtsforhold i det samfund, som beretningen handlede om. Denne hjemmelsmandsprofil får Ólafur Halldórsson til at komme med et bud på, hvem hjemmelsmanden var, nemlig Einarr sysselmand, som bliver nævnt i sagaens afslutningskapitel. Som sysselmand i den norske konges tjeneste måtte Einarr have været vel bekendt med Gulatingslovens paragraffer, og som skibsejer var han berejst. At der var tale om Einarr mente Ólafur Halldórsson finder yderligere støtte i, at Einarr ser ud til at have haft en islandsk kone og dermed slægtsskabsforbindelser til Island i sagaforfatterens samtid. Dette begrunder han med, at der i udredningen af slægten efter Snorri gode i Melabók bliver nævnt, at en Einarr fra Færøerne var gift med en datter til Goðormr, som $i$ henhold til det angivne antal slægtsled har levet i tiden omkring det 13. århundredeskifte. Efter Ólafur Halldórssons mening var han derfor en af sagaforfatterens hjemmelsmænd, og sandsynligvis den eneste, eftersom han passer til profilen på nærmest alle punkter, også dem, som Foote i sin 
opstilling af lovopfattelsen i sagaen redegjorde for: "Hann var kominn út af Sigmundi Brestissyni, og má pá gera ráo fyrir að hann hafi kunnað að segja eitthvað frá honum og ættmennum hans. Hins vegar virðist ljóst að hann hafi ekki setið yfir höfundi sögunnar meðan hún var samin; höfundurinn virðist ekki hafa átt neinn kost á að fylla í skörðin par sem hann skorti fróðleik um mannfræði og staðhætti i eyjunum." (Ólafur Halldórsson 1987: 211).

Der kan imidlertid også indgives et andet bud på grundlag af den samme hjemmelsmandsprofil, som Ólafur Halldórsson tegnede, nemlig at lokalitets- og slægtskabsoplysningerne i sagaen stammede fra en anden kendt færing, som dog var død kort før sagaen blev skrevet. Her tænker jeg på kong Sverrir (d. 1202), som siden sit femte år voksede op hos sin onkel, Rói, som i 1162 blev Færøernes biskop, og hos ham fik sin gejstlige uddannelse og indvielse, før han som 24 årig fik sandheden om sin kongelige byrd at vide. Under sin opvækst hos biskop Rói har Sverrir uden tvivl både hørt historier om de gamle høvdinger og om Sigmundr Brestisson, som bragte kristendommen til landet. Vi kan også regne med, at han, som efter eget sigende havde i udsigt at blive biskop, blev oplært i norsk og kirkelig lov og ret, og antagelig også gammel norrøn herskerideologi, især når det tages med i betragtning, at denne ideologi lå til grund for hans hævdelse af sin kongsret og hans senere strid med den romerske kirke. Ligeledes kan vi regne med, at han, i følgeskab med biskop Rói under visitationsrejser i det færøske stift, har erhvervet sig godt og grundigt kendskab til strømforhold i de færøske farvande og de færøske naturforhold i øvrigt. I Sverris saga hører vi også om hans færden i de norske landskaber og skove, både Østenfjelds og i vest, blandt andet i Orkadalen og Tunsberg, og som nævnt hører vi også om markedet på Haløre.

Flere forhold kan anføres, som tyder på, at der var en forbindelse mellem Færeyinga saga og kong Sverrir. Som det første kan nævnes, at Færeyinga saga tilsyneladende blev skrevet i det samme klostermiljø som Sverris saga og i en tid, mens forfatteren af denne saga, abbed Karl Jónsson (d. 1212/1213), endnu kan have været i live. Abbeden opholdt sig hos kong Sverrir i Norge i årene 1185-1188, hvor han skrev Sverris sagas første del, Grýla, mens kongen fortalte, hvad der skulle stå. Derefter rejste abbed Karl hjem til sit kloster, hvor han færdigskrev sagaen. Vi kan formode, at abbeden under sit ophold også har taget notater fra sine samtaler med kongen til senere benyttelse, blandt andet om forholdene på Færøerne, hvor kongen var vokset op. Som det andet kan nævnes, 
at nogle lokalitetsangivelser er fejlagtige, nemlig beskrivelsen af øen Austrey i kapitel 57 og sammenblandingen af øerne Dimun og Skufey i kapitlerne 22 og 24, og at dette kan tolkes som at forfatteren ikke baserede sine lokalitetsangivelser på præsente oplysninger, men på hukommelse om noget, som han eller en i hans nærmiljø havde hørt i fortiden (jfr. Fær., kap. F57.38-41. Halldórsson 1987: 195-196). Altså at det kan tænkes, at oplysningerne om de færøske lokaliteter og slægter blev overført via abbed Karl og stammede fra hans samtaler med kong Sverrir i årene 1185-1188. Som det tredje kan nævnes, at interessen $i$ at fortælle en historie, som gav sysselmændene i forfatterens samtid historisk legitimitet, kan tilskrives påvirkning fra kong Sverrir, eftersom sysselmandsinstitutionen i henhold til Sverris saga ser ud til at have fået en mere håndfast form i skatlandene i 1195 i forbindelse med kongens opgør med orknøjarlen og de shetlandske stormænd efter øskeggeopstanden året før. Som det fjerde kan nævnes, at det er tankevækkende, at yndlingsformuleringen "válk ok vandræði" i kong Sverrirs taler også forekommer i kong Óláfr Tryggvasons tale i Færeyinga sagas kapitel 29. I talen bliver beretningen om den unge Sigmundrs prøvelser og skæbne før han vandt sit høvdingedømme opsummeret og sammenlignet med kong Olavs lignende prøvelser og skæbne før han blev konge. Talen ligner en tale, som kong Sverrir kunne have holdt, og tankegangen med prøvelser som legitimeringsgrundlag for

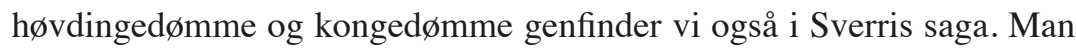
kan derfor nære en mistanke om, at talen er kong Sverris værk og ligger til grund for forfatterens beretning om Sigmundr Brestissons skæbne før han blev høvding. I forbindelse med dette kan nævnes, at Ólafía Einarsdóttir tolkede omtalen af "vitorð”" fra kong Sverrir i prologen til Sverris saga i Flateyjarbók som tegn på, at abbeden i Pingeyri under sin skrivning af Sverris saga også opretholdt skriftlig kontakt med kong Sverrir efter 1188 , blandt andet med modtagelse af excerpter af kongens taler (Ólafía Einarsdóttir 2001: 112). Ligeledes er det tankevækkende, at Puríðrs drøm i kapitel 54 har de samme karaktertræk som drømmene i Sverris saga, hvis oprindelse ud fra sagaens prolog kan tilskrives kongen selv.

Enten kong Sverrir var hjemmelsmand til de lokale oplysninger i Færeyinga saga eller ej, så tyder herskerideologien, som kommer til syne, på, at sagaforfatteren var påvirket af denne konges herskerideologi. Den særlige underfundige stil, med det særlige fokus på antagonisme til det kristne høvdinged $\varnothing m m e ~ i$ forhold til fuldbyrdelsen af det samme, og beskrivelsen af Sigmundr Brestissons prøvelser for at opnå sin ret, giver også indtryk af, at kong Sverrir har en underforstået rolle i fortællingen. 
På den samtidige læser må fortællingen have givet et indtryk af en forbindelse mellem Prándr, Sigmundr og Sverrir. Prándr repræsenterede det gamle lovsamfunds værdier, som også Sverrir forsvarede, og ligesom Sigmundr virkede Sverrir, med basis i både det gamle og det nye, for etableringen af en ny form for regime. Ligesom Sigmundr var han ikke den førstefødte, og ligesom ham var han, i henhold til Sverris sagas kronologi, 27 år, da han, efter at have gennemgået lignende prøvelser som Óláfr Tryggvason under sin opvækst i udlændighed, i 1177 blev konge. Man kan derfor argumentere for, at forfatteren af Færeyinga saga har kong Sverrirs kamp for magten og hans strid med den romerske kirke om sin kongsret i tankerne, mens han former sin fortælling.

\section{Samtid og fortid}

Den underfundige fortællestil i Færeyinga saga tyder på, at sagaen er skrevet med et underholdningsmotiv for øje. Men det, at et politisk motiv er så åbenlyst, giver anledning til at slutte, at underholdningsmotivet var sekundært i forhold til det politiske motiv. I den tid, da Færeyinga saga blev skrevet, var striden med den romerske kirke endnu på sit højeste. Kong Sverrir var død, men han var endnu bandlyst, og Sverrirs-ættens forhold til pavedømmet var i henhold til det overleverede diplommateriale køligt helt frem til 1246, da parterne genoptog kontakt i forbindelse med kong Hákons ønske om kirkelig kroning (Reg. Norv., nr. 756, 761, 763, 769, 771). I Island var der en dramatisk kirkestrid, hvor hovedpersonen, biskop Guðmundr Arason i Hólar (1202-1237), kom på kant med stormændene i stiftet og blev forment adgang til sin kirke. En af hans tidligere venner, men uven i 1210, var Gunnlaugr Leifsson i klosteret i Pingeyri (jfr. Finnur Jónsson 1923: 394). Denne strid havde samme udspring, nemlig i spørgsmålet om kirkens frigørelse fra verdslig indflydelse, hvor fronterne i sidste ende blev repræsenteret af ærkebiskoppen og kongen. Det ser derfor ud til, at munkene ved Pingeyrarklosteret i konflikten ikke spillede på de samme strenge som deres overordnede, ærkebiskoppen, men på de strenge, som i Norge var repræsenteret af kong Sverrirs gamle parti, Birkebeinerpartiet. Vi har således grund til at formode, at den skriftlige produktion i Pingeyrarklosteret i denne tid har været præget af en vis forsigtighed i forhold til den aktuelle kirkestrid, hvor Sverrirsættens kongedømme endnu ikke havde konsolideret sig. Den særlige 
stil i sagaen, hvor også kong Sverrir ser ud til at have en underforstået rolle i fortællingen, kan derfor ses som udtryk for, at Færeyinga saga oprindelig blev skrevet som en forsigtig form for kampskrift til fremme for det rigskongedømme, som kong Sverrir stod for, i en tid, hvor det var nødvendigt for de gejstlige i klosteret i Pingeyri at udvise forsigtighed i deres skrivning for ikke at udsætte sig for ærkebiskoppens vrede.

I forhold til spørgsmålet om sagaens historiske kildeværdi viser gennemgangen, at det $\mathrm{i}$ anvendelsen af materialet er nødvendigt at tage hensyn til, at en andel af beretningen er en forfatterkonstruktion ud fra politiske motiver i samtiden, og at en andel kan anses som kodificering af mundtlig tradition med færøsk oprindelse om forhold ca. 200 år før nedskrivningstidspunktet. Uanset om det var Einarr sysselmand eller hans opdragsgiver, kong Sverrir, der var sagaforfatterens hjemmelsmand, så bør sagaens oplysninger om slægter og stridighederne imellem dem fra historievidenskabeligt synspunkt anses som traditionsmateriale fra begyndelsen af det 13. århundrede. Som Liestøls unders øgelser fra 1922 viste, er der stor sandsynlighed for, at traditionsoplysninger, især slægtsskabsoplysninger og historier i den forbindelse, bevarer sandhedsværdi efter så lang tid og endog længere (Liestøl 1922: 156-165). Efter den lange debat inden for historieforskningen om fortidssagaernes kildeværdi synes konklusionen i dag at være, at oplysninger, som ikke kan afvises som anakronistiske eller som værende et resultat af senere bearbejdelse, kan anses som troværdige (jfr. Titlestad 2009; Helle 2011). Følgelig må konstruktionerne, som kan stadfæstes, fra historievidenskabeligt synspunkt anses som utroværdige, dog med det forbehold, at beretningerne ser ud til at tage afsæt i folkelig tradition i begyndelsen af det 13. århundrede. Fra historievidenskabeligt synspunkt må disse beretninger derfor anses som beretninger med usikker historisk kærne, og i Færeyinga saga drejer det sig om historierne om Prándrs kup på markedet på Haløre, Sigmundrs og Pórirs opvækst i de norske skove, Sigmundrs fortræffelighed som kong Óláfr Tryggvasons jævnbyrdige og om, hvordan Óláfr helgis skatteopkræver blev dræbt. Når vi sigter disse sandsynlige konstruktioner fra, står vi tilbage med en beretning, der kan anses som traditionsbåret i begyndelsen af det 13. århundrede. Denne beretning handler om, at Færøerne før det første årtusindeskifte blev styret af to høvdingeslægter, Hofs-slægten og Gotuskeggja-slægten, at kristendommen blev indført på Færøerne af Sigmundr Brestisson i samarbejde med kong Óláfr Tryggvason omkring år 1000, og at kong Óláfr helgi gjorde et mislykket fors $\emptyset \mathrm{g}$ på at bringe færingerne under norsk lovgivning og beskatning, og at rigskongedømmets ekspan- 
sive politik i nybyggersamfundet bar frugt, mens Magnús góði var konge (1035-1047), efter at de færøske høvdingeslægter var blevet forenet med ægteskab. Derudover ser det ud til at være på grundlag af en færøsk meddelers udsagn, at sagaen er iklædt et norsk lovsprog, og følgen af denne slutning er, at på det tidspunkt, da sagaen blev skrevet, var norsk lovgivning gældende på Færøerne, og at denne i henhold til den mundtlige tradition i det 13. århundredes begyndelse var blevet introduceret i Óláfr helgis niende år som konge, dvs. i 1024.

\section{Konklusion}

Målet med denne artikel var at vurdere, hvordan Færeyinga saga skal anses som historisk kilde. Unders $ø$ gelsen er foretaget med udgangspunkt i spørgsmålet, hvilke slutninger man ud fra det, som den litteraturhistoriske forskning om Færeyinga sagas overlevering og tekstuelle afhængighedsforhold er kommet frem til, kan drage om sagaens ophav og de politiske faktorer, der gjorde sig gældende i forbindelse med dannelsen af sagaens udsagn og form. Konklusionen er, at Færeyinga saga med stor sandsynlighed blev skrevet i det samme litterære miljø og i samme tid som Sverris saga, nemlig i klosteret i Pingeyri i Nordisland i løbet af de første par årtier af det 13. århundrede, og at forfatteren baserede sin redegørelse af naturforhold og juridiske forhold på Færøerne på oplysninger fra en hjemmelsmand, som havde hjemsted på Færøerne. Af fortællingen kan man slutte, at der var en vis tidsafstand imellem forfatter og fortæller, og det tyder på, at sagaen er skrevet med grundlag i hukommelse og notater. Den herskerideologiske tankegang, som kommer til syne, tyder på, at sagaen tilhører tiden før det norske rigskongedømme konsoliderede sig på grundlag af romersk katolsk kongeideologi i tiden omkring kong Hákon Hákonarsons kroning i 1247, og dette støtter den litteraturhistoriske datering af sagaen til begyndelsen af det 13. århundrede. I sagaen ses tegn på, at der var en forbindelse mellem forfatteren og kong Sverrir, som i sin barndom og ungdom boede på Færøerne, hvor han fik sin gejstlige uddannelse, og at kongen har en underforstået rolle i fortællingen. I forhold til spørgsmålet om sagaens ophavssituation ser det ud til, at Færeyinga saga, set i lyset af den politiske situation i Norge og Island og i forhold til den pavelige politik i de to første årtier af det 13. århundrede, skal anses som et antagonistisk skrift, der taler for kong Sverrirs kongedømme. 


\section{Litteratur}

Bagge, Sverre, 1996: From Gang Leader to the Lord's Anointed: Kingship in Sverris Saga and Hákonar saga Hákonarsonar. Odense University Press.

Bagge, Sverre, 2007: “Gang leader" eller “The Lord's anointed” i Sverris saga? I: Scripta Islandica 58. S. 101-119.

Berman, Melissa, 1985: The Political Sagas. I: Scandinavian Studies 57(2). S. 113-129.

Fær.: Ólafur Halldórsson, 1987: Fareyinga saga. Reykjavík: Stofnun Árna Magnússonar á Íslandi.

Finnur Jónsson, 1923: Den oldnorske og oldislandske Litteraturs Historie. Andet bind. København.

Finnur Jónsson, 1927: Fareyinga saga, den islandske saga om faringerne. København: Det Kongelige Nordiske Oldskriftselskab.

Foote, Peter, 1970: On legal terms in Færeyinga saga. I: Fróðskaparrit 18. S. 159-175.

Foote, Peter, 1988: Observations on Orkneyinga saga. I: St Magnus Cathedral and Orkney's twelfth-century renaissance. Red. af B. E. Crawford. Aberdeen: Aberdeen University Press. S. 192-207.

Helgi Guðmundsson, 2002: Færeyinga saga. I: Land úr landi. Greinar. Reykjavík. S. 13-27.

Helle, Knut, 2005: The position of the Faeroes and other "tributary lands" in the medieval Norwegian dominion. I: Viking and Norse in the North Atlantic. Selected Papers from the Proceedings of the Fourteenth Viking Congress, Tórshavn, 19-30 July 2001. Red. af A. Mortensen og S. Arge. Tórshavn. S. 11-21.

Helle, Knut, 2011: Hvor står den historiske sagakritikken i dag? I: Collegium Medievale 24. S. 50-86.

Heller, Rolf, 1998: Laxdæla saga und Færeyinga saga. I: Alvíssmál 8. S. 85-92.

Jesch, Judith, 1993: History in the "political sagas". I: Medium Avvum. Society for the Study of Medieval Languages and Literature, 62(2). S. 210-220. doi: $10.2307 / 43629554$.

Lie, Hallvard, 1937: Studier i Heimskringlas stil, dialogene og talene. Oslo.

Liestøl, Knut, 1922: Norske attesogor. Kristiania.

Ljungqvist, Fredrik Charpentier, 2006: Kristen kungaideologi i Sverris saga. I: Scripta Islandica 57. S. 79-95.

Lönnroth, Lars, 2006: Sverrir's Dreams. I: Scripta Islandica 57. S. 97-110.

Mortensen, Andras, 2005: One Facet of the Tendency in Færeyinga saga. I: Viking and Norse in the North Atlantic. Selected Papers from the Proceedings of the Fourteenth Viking Congress, Tórshavn, 19-30 July 2001. Red. af A. Mortensen og S. Arge. Tórshavn. S. 87-91.

North, Richard, 2005: Money and Religion in Færeyinga saga. I: Viking and Norse in the North Atlantic. Selected Papers from the Proceedings of the Fourteenth Viking Congress, Tórshavn, 19-30 July 2001. Red. af A. Mortensen og S. Arge. Tórshavn. S. 60-75. 
Ólafía Einarsdóttir, 1964: Studier i kronologisk metode i tidlig islandsk historieskrivning. Bibliotheca Historica Lundensis. Ediderunt Sture Bolin et Jerker Rosén 13. Stockholm: Natur och Kultur.

Ólafía Einarsdóttir, 1995: Om samtidssagaens kildeværdi belyst ved Hákonar saga Hákonarsonar. I: Alvíssmál 5. S. 29-80.

Ólafía Einarsdóttir, 2001: Rez. Sverre Bagge. From Gang Leader to the Lord's Anointed: Kingship in "Sverris saga and Hákonar saga Hákonarsonar". I: Alvíssmál 10. S. 111-115.

Ólafur Halldórsson, 1987: Fareyinga saga. Reykjavík: Stofnun Árna Magnússonar á Íslandi.

Ólafur Halldórsson, 2006: Fareyinga saga, Føroyinga sфga. Reykjavík: Hið íslenzka fornritafélag.

Reg. Norv.: Gunnes, E., 1989: Regesta Norvegica, I, 822-1263. Oslo: Norsk historisk kjeldeskrift-institutt.

Steinsland, Gro, 2005: The Mythology of Rulership and the Saga of the Faroe Islanders. I: Viking and Norse in the North Atlantic. Selected Papers from the Proceedings of the Fourteenth Viking Congress, Tórshavn, 19-30 July 2001. Red. af A. Mortensen og S. Arge. Tórshavn. S. 76-86.

Steinsland, Gro, 2011: Origin Myths and Rulership. From the Viking Age Ruler of Medieval Historiography: Continuity, Transformations and Innovations. I: Ideology and Power in the Viking and Middle Ages. Red. af G. Steinsland et al. Leiden Boston: Brill. S. 15-67. doi: 10.1163/ej.9789004205062.i-408.7.

Sverris saga (Flateyjarbók) = Gudbrand Vigfusson og C. R. Unger, 1862: Flateyjarbok, en Samling af norske Konge-sagaer med indskudte mindre Fortallinger om Begivenheder i og udenfor Norge, samt Annaler. Bd. II. Kristiania.

Titlestad, Torgrim, 2009: Tilbake til sagaene. I: Nytt Norsk Tidsskrift 1. S. 3-12.

Wærdahl, Randi Bjørshol, 2011: The Incorporation and Integration of the King's Tributary Lands into the Norwegian Realm, c. 1195-1397. Leiden Boston: Brill.

\section{Summary}

The article discusses how Færeyinga saga should be regarded as a historical source. The study is based on the question, which conclusions we from the literaturehistorical research on the tradition and textual dependency of Færeyinga saga can draw about the origin of the saga and which political factors were present in connection with the creation of its propositions and form. The conclusion is that Færeyinga saga very likely was written in the monastery at Pingeyri in northern Iceland during the two first decades of the 13th century, and that the author based his presentation on natural and legal conditions on information from an informant who came from the Faroe Islands. The ideological understanding of rulership 
that appears indicates that there was a connection between the author and King Sverrir, and the king seems to have an implied role in the narrative. In relation to the question of the origin of the saga, it seems that the Færeyinga saga, in the light of the political situation in Norway and Iceland and in relation to the papal politics in the first two decades of the 13th century, should be regarded as an antagonistic writing that speaks for the rulership of King Sverrir.

Keywords: Færøerne, Færeyinga saga, politisk saga, herskerideologi, legitimitet, Pingeyri, kong Sverrir. Faroe Islands, Færeyinga saga, political saga, ruler ideology, legitimacy, Pingeyri, King Sverrir.

\section{Andras Mortensen}

Fróðskaparsetur Fфroya / University of the Faroe Islands

Søgu og samfelagsdeildin / Faculty of History and Social Sciences

ORCID iD 0000-0002-5819-5192 


\title{
Det henrettede par i dobbeltgravhøjene i Kópavogur syd for Reykjavík i Ísland
}

\author{
GuĐMundur ÓlafsSON OG Lise GJEDSSø BERTELSEN
}

\section{Indledning}

I året 1704 fandt et mord på en mand ved navn Sæmundur Pórarinsson sted ved Skötufoss i Elliðaá, ${ }^{1}$ en fos nordøst for Kópavogur (fig. 1). En yngre mand ved navn Sigurður Arason og den afdøde mands kone, Steinunn Guðmundsdóttir, blev anklaget for drabet samt fundet skyldige heri på Kópavogurs ting, og som straf dømtes de begge til døden samme sted samme år. Foråret 1988 udførtes en arkæologisk udgravning af to sammenhørende gravhøje, i folkemunde kaldet Hjónadysjar/pardysserne, nær Kópavogurs å.

Omstændighederne bag tragedien var, at i Árbær boede den 26årige unge mand Sigurður Arason sammen med sin mor Guðrún Grímsdóttir og en stor dreng Oddur Böðvarsson, og de var naboer til ægteparret Sæmundur Pórarinsson og dennes 43årige hustru Steinunn Guðmundsdóttir. Sæmundur Pórarinsson var ca. 40 år gammel; han havde ingen børn, derfor heller ikke med Steinunn. Steinunn havde været gift to gange tidligere. Hendes første mand hed Bergur, og med ham havde hun sønnen Guðmundur på 20 år og datteren Guðrún på 19 år. Steinunns anden mand hed Erlendur, og med ham havde hun sønnen Bergur på 7 år. Samtlige

\footnotetext{
${ }^{1} A ́$ på islandsk betyder å på dansk. I artiklen her er anvendt islandsk stavemåde for samtlige islandske navne og stednavne, bortset fra Pjóðminjasafn Íslands, som på dansk hedder Islands Nationalmuseum, samt Háskóli Íslands, som på dansk hedder Islands Universitet.
}

Ólafsson, Guðmundur og Lise Gjedssø Bertelsen. 2019. Det henrettede par i dobbeltgravhøjene i Kópavogur syd for Reykjavík i Ísland. Scripta Islandica 70: 37-59. 


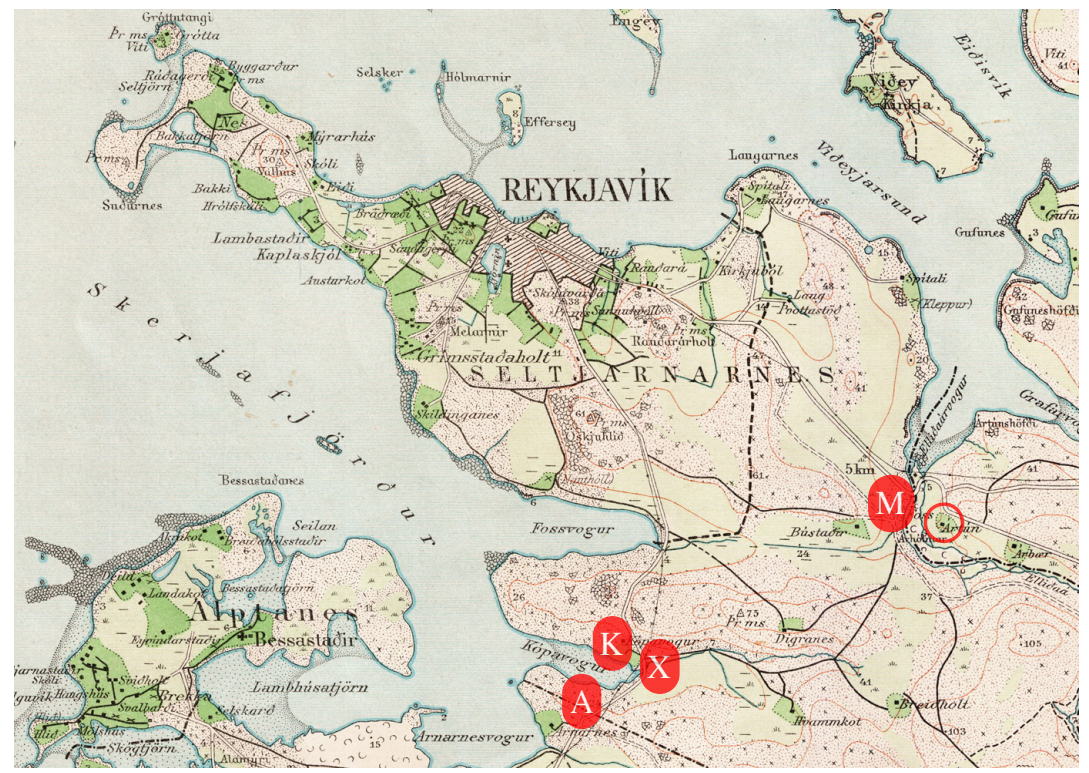

Fig. 1. Kort over området med markering af relevante lokaliteter som Árbær $\mathbf{O}$, Kópavogurs ting $\mathbf{K}$, gravhøjene $\mathbf{X}$, mordpladsen $\mathbf{M}$ og Arnarnes A. Detalje af generalstabens topografiske kort nr. 27NA, 1:50:000 fra 1909 over Reykjavík med omgivelser. (C) Landmælingar Íslands.

tre børn boede hos Steinunn og Sæmundur. Steinunn var Sæmundur utro med Sigurður.

22. september 1704 ankom Sigurður til Bústaðir og Breiðholt og fortalte, at Sæmundur dagen før havde begivet sig afsted mod Hraunsholt men, at han ikke var nået frem. Derfor havde Sigurður sammen med flere mænd begivet sig ud for at lede efter Sæmundur og havde fundet ham død ved foden af Skötufoss i Elliðaá. Her berettede Sigurður for mændene, at Steinunn - inden Sigurður tog ud for at lede efter Sæmundur - havde fortalt ham, at hvis Sæmundur skulle blive fundet død, så skulle liget ikke tages med hjem til Árbær, men bringes direkte til kirken i Gufunes, hvortil de hørte, og således blev det.

Der opstod hurtigt mistanke om, at Sæmundur var blevet myrdet, og Sigurður begav sig derfor til præsten Pórður Konráðsson i Mosfell, som også betjente Gufunes kirke, for at bede ham om hjælp til at forsvare sin uskyld i den forbindelse. Derfor red Pórður med Sigurður til gården Skildinganes, for at snakke med bonden, som havde sagt, at det ikke stod 
rigtigt til med Sæmundurs død. Siden tog de til Lambastaðir for at tale med præsten der, og til sidst til sysselmanden i Nes for at bedyre Sigurðurs uskyld. Efter disse besøg tog Sigurður, som var fisker, tilbage til Örfirisey, hvor hans båd var stationeret. Han arbejdede videre som fisker, indtil han blev arresteret.

Den begrundede eller ubegrundede mistanke om, at Sæmundur kunne være blevet myrdet, var der dog endnu ikke beviser på. Det, som ansås mistænkeligt, var, at Sæmundurs fundne lig ikke var opsvulmet, lige så lidt som dets mund eller svælg var fyldt med vand, som det ellers er karakteristisk ved drukneulykker.

17. oktober skrev fogeden Niels Kjær et brev til amtmand Páll Beyer, hvori han spurgte, om han skulle arrestere Sigurður på baggrund af ovennævnte udtalelser. Amtmanden besluttede, at Sigurður skulle bevogtes nat og dag.

18. oktober blev Sigurður arresteret af sysselmanden i Nes, Jón Eyjólfsson. Nogle dage gik, hvor Sigurður blev ved med at nægte at have gjort noget galt. Amtmand Páll Beyer skrev derfor brev til biskop Jón Vídalín på Skálholt og bad om tilladelse til at grave Sæmundurs lig op til nærmere undersøgelse.

24. oktober besvarede biskoppen amtmandens brev, hvori han bebrejdede præsten Pórður Konráðsson, at denne havde forsvaret Sigurðurs uskyld, og sagde, at Sæmundur sandsynligvis var blevet myrdet, samt gav sin tilladelse til, at liget blev gravet op. Amtmand Páll Beyer viderebragte nyhederne til Sigurður, der derpå straks ændrede sin forklaring og tilstod mordet på Sæmundur tilskyndet dertil af Steinunn.

Inden dommen tilstod Sigurður således at have myrdet Sæmundur. Sigurður berettede, at han var taget ud med Sæmundur under påskud af, at de skulle fiske ved Skötufoss, men med sig havde Sigurður hjemmefra taget et bræt med til at slå Sæmundur ihjel. Sigurður fortalte, at han havde gjort dette på opfordring af Steinunn. Først ville Steinunn ikke vedkende sig delagtighed i mordet. Men hun og Sigurður blev flyttet i arrest på Seltjarnarnes, og sagen blev ført til doms.

12. november svarede biskop Jón Vídalín og professor ved Københavns Universitet Árni Magnússon, som på det tidspunkt opholdt sig i Skálholt, i næsten enslydende breve amtmand Páll Beyer om deres syn på Steinunns strafudmåling. Amtmanden havde forinden udbedt sig deres råd om, hvilken dom, der ville være den rette for Steinunn, eftersom hun ikke direkte havde taget del i mordet. Både Jón Vídalín og Árni Magnússon anbefalede, at Steinunn måtte dømmes til døden, eftersom det stred mod 
kristen tro, når en så fordærvet kvinde som Steinunn, der længe havde haft et syndigt forhold til en mand, fik ham til at myrde sin ægtemand.

14. november blev Sigurður og Steinunn dømt til døden på Kópavogurs ting hos dommer Sigurður Björnsson og amtmand Paul Beyer. Sigurður blev dømt til halshugning med hovedet derefter sat på stage. Steinunn blev dømt til drukning. Begge skulle derpå begraves under stenhøje ved almen vejen, altså $i$ uindviet jord.

15. november blev dommene eksekveret som foreskrevet, Sigurður blev halshugget på tunet, nord for tinghuset. ${ }^{2}$ Steinunn blev druknet i Kópavogurs å. Begge blev gravlagt under stensætninger tæt ved almen vej, så forbipasserende let kunne kaste sten på deres grave. I islandske annaler fortælles, at amtmand Páll Beyer beordrede, at Sigurðurs hoved skulle sættes på stage ved hans grav (Annálar 1400-1800, I: 451-453; II: 353, 555; III: 526).

Foruden de islandske annaler bygger ovennævnte beretning på to meget udførlige artikler, som blev publiceret i Árbók hins Íslenzka fornleifafjelags 1929 og i Lesbók Morgunblaðsins år 1943 (Matthías Pórðarson 1929: 29-33; Árni Óla 1943: 445-448).

I en anden artikel i Lesbók Morgunbladsins år 1995 fortælles blandt andet, at de to menneskers dramatiske død betød, at der på gårdene i omegnen derefter blev fortalt sagn om gengangeri relateret til dem men, at man ikke ved mere om Steinunn og Sigurðurs videre skæbne efter henrettelserne end, at deres grave skulle være blevet fundet under vejarbejde engang i første halvdel af 1900-tallet (Helgi Sigurðsson 1995: 11).

Vi vil med artiklen her føje yderligere til opklaring af sagen. Stedet, hvor mennesker igennem tiden var blevet dømt samt henrettet på Kópavogurs ting og begravet tæt ved, var naturligvis hjemsøgt af sagn om spøgeri og gengangeri. Dette gjaldt som nævnt også dobbeltgravhøjene ved den gamle vej mellem Kópavogurs å og Arnarnes. Ligeså var der berettet om fund af menneskeknogler, som man mente, stammede fra parhøjene. Der var også beretninger om, at vejarbejdere $\mathrm{i}$ året 1938 havde fundet et kranie med meget hår på ved Kópavogurs å samt nogle knogler. De præcise findesteder var imidlertid ikke udpeget (Guðrún Sveinbjarnardóttir 1986: $3-4)$.

\footnotetext{
${ }^{2}$ Tinghuset blev udgravet av arkæolog Guðrún Sveinbjarnardóttir 1972-1975, jf. Guðrún Sveinbjarnardóttir 1986.
} 


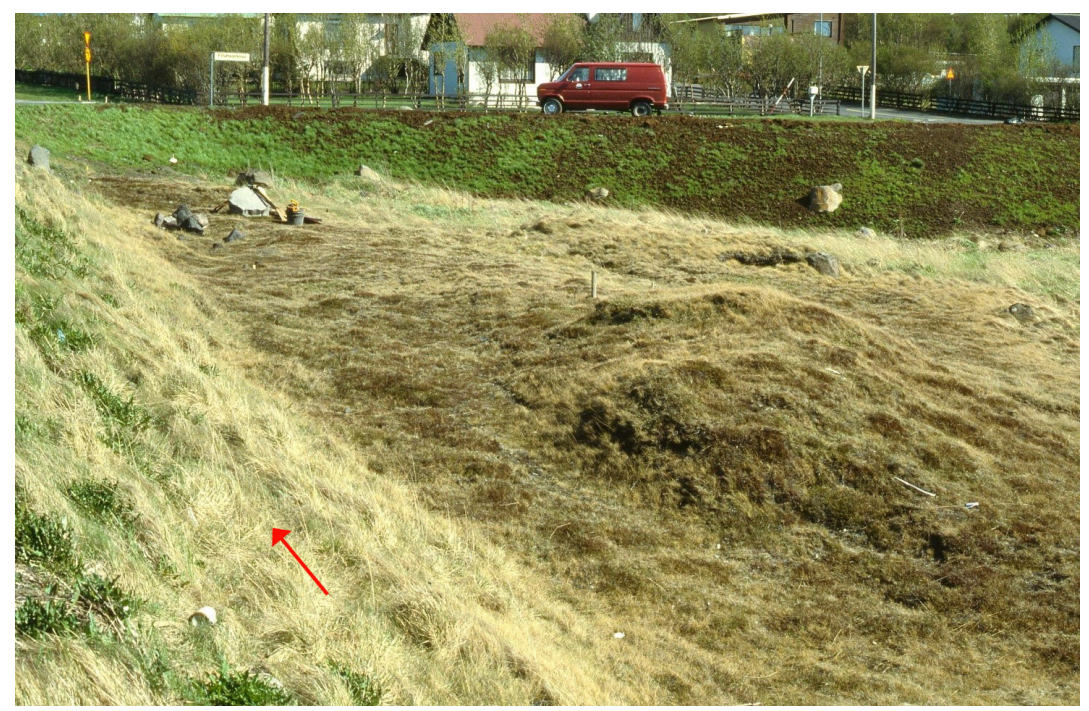

Fig. 2. Foto af gravpladsen med de to sammenhørende gravhøje med en lavning imellem. Umiddelbart inden unders $\varnothing$ gelsen 1988. I baggrunden ses Fífuhvammurs vejen. Pilen viser nordlig retning. Foto: Guðmundur Ólafsson.

\section{Den arkæologiske udgravning i foråret 1988}

Den arkæologiske udgravning i foråret 1988 var begæret af det islandske Vejvæsen (Vegagerðin) i forbindelse med en kommende udvidelse af hovedvejen fra Reykjavík til Hafnarfjörður. Inden den arkæologiske udgravning sås to mindre forhøjninger liggende tæt ind til hinanden med en lavning imellem i hjørnet mellem Hafnarfjörðurs vejen og Fífuhvammurs vejen, og ifølge folkefortællingerne skulle forhøjningerne være gravhøje (Guðmundur Ólafsson 1996; Guðrún Sveinbjarnardóttir 1986: 14-15; Matthías Pórðarson 1929: 29-33) (fig. 2). Den nye vej skulle føres hen over dette område, hvor forhøjningerne lå, så disse måtte undersøges arkæologisk, før deres historie gik tabt for altid.

Ved udgravningen kom to forhøjede samlinger av sten straks til syne

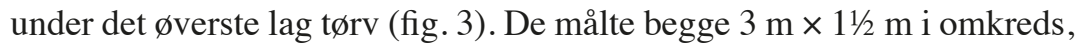
og der var kun $1 \mathrm{~m}$ imellem dem. Det var klart, at der her var tale om to grave, som oprindeligt havde været pakket med sten, såkaldte stendysser og, at de to grave hørte sammen. Oven på gravenes $\emptyset$ verste oprindelige stenlag lå et lag af mange små og forskelligartede sten, som i tidens løb var 


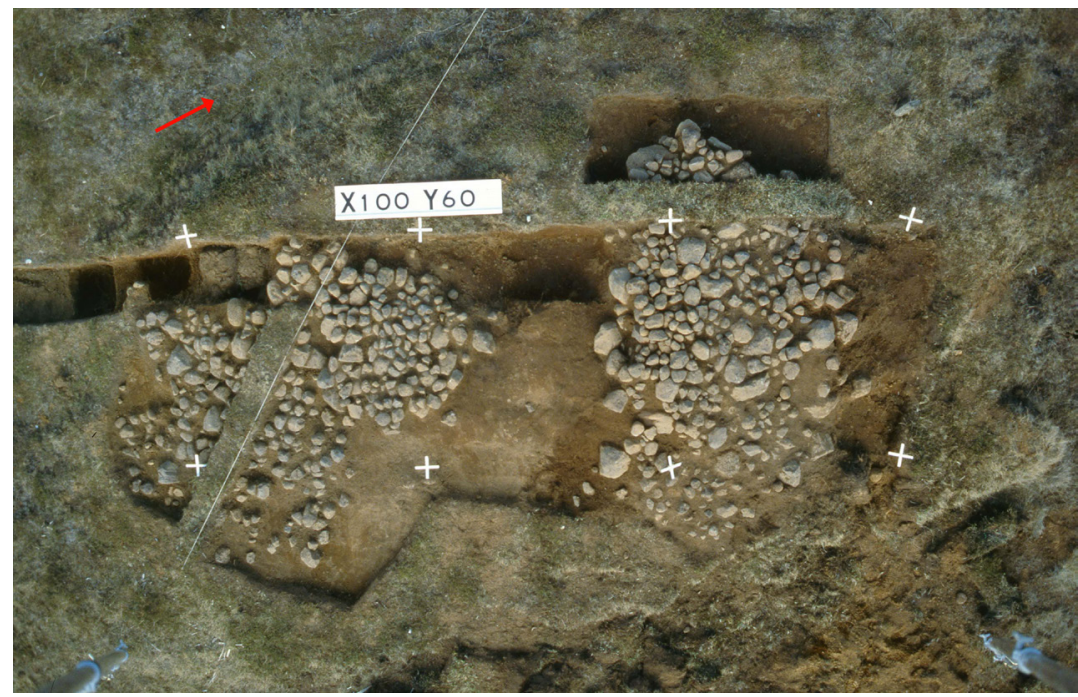

Fig. 3. De to gravhøjes $\varnothing$ verste oprindelige stenlag efter, at græst $\varnothing r v e n$ og stenlaget med de små påkastede sten var fjernet. Foto: Guðmundur Ólafsson.

kastet på de to gravhøje af passerende på vejen. I folketroen fandtes der mange metoder til at forhindre spøgeri og gengangeri, og denne handling skulle ifølge overtroen beskytte de forbipasserende imod, at de gravlagte skulle kunne gå igen (Jón Árnason 1954: 660-662). Efter at dette øverste sekundære lag af mange slags småsten var afdækket og fjernet, kom et nyt lag sten for dagens lys. Dette lag bestod af større og langt mere ensartede sten og var de oprindelige stenrøsernes $\emptyset$ verste lag.

\section{Grav 1}

Under denne stenrøses oprindelige $\varnothing$ verste lag fandtes en nord-nord $\varnothing$ stsyd-sydvest vendt grav, der var $1,85 \mathrm{~m}$ lang og $1 / 2 \mathrm{~m}$ bred. På gravens bund lå skelettet af en kvinde (fig. 4). Liget, som var ca. 1,60 m langt, var lagt i graven med korslagte ben. Armene lå i en usædvanlig stilling. Den venstre arm lå skråt ned mod maven. Den højre arm lå skråt op mod brystet. Hænderne var knyttede krampagtigt. Kraniet lå ved skelettets skuldre, men i en mærkelig forvreden stilling. De to fortænder i overmunden manglede. Bag ved kraniets nakke lå den ene fortand, og to halshvirvler lå uden for normale leje. Oven på rygraden og højre arm fandtes der svage spor av tøjrester. De sås kun som en lille farveforskel i jorden, eftersom 


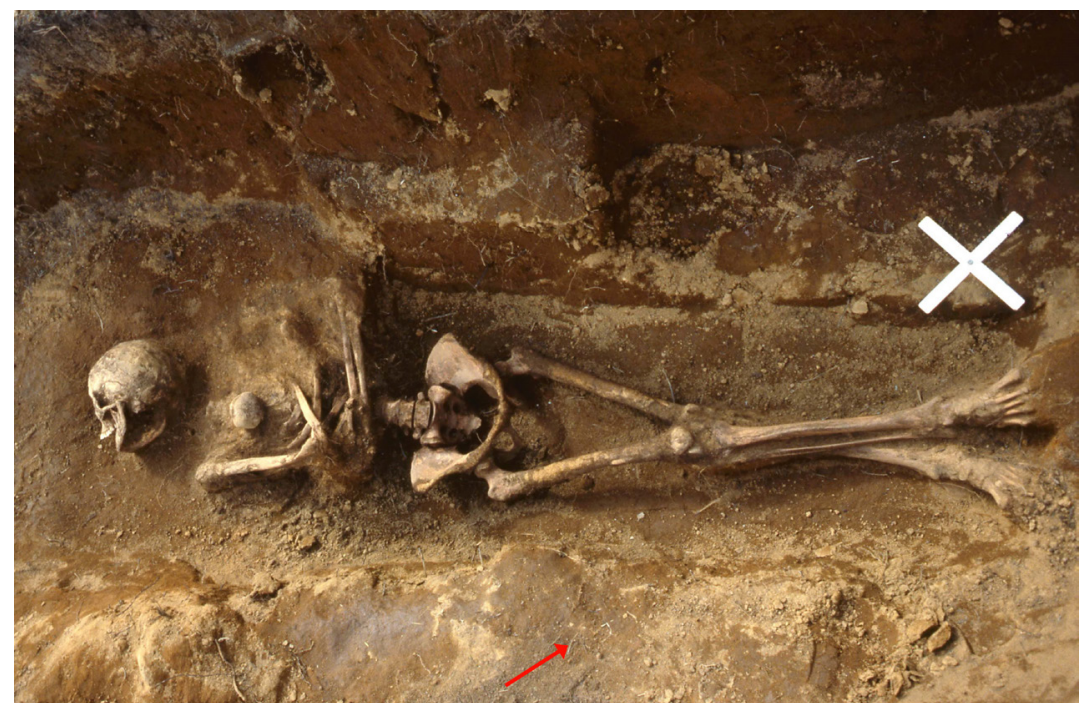

Fig. 4. Grav 1 med velbevaret kvindeskelet. Foto: Guðmundur Ólafsson.

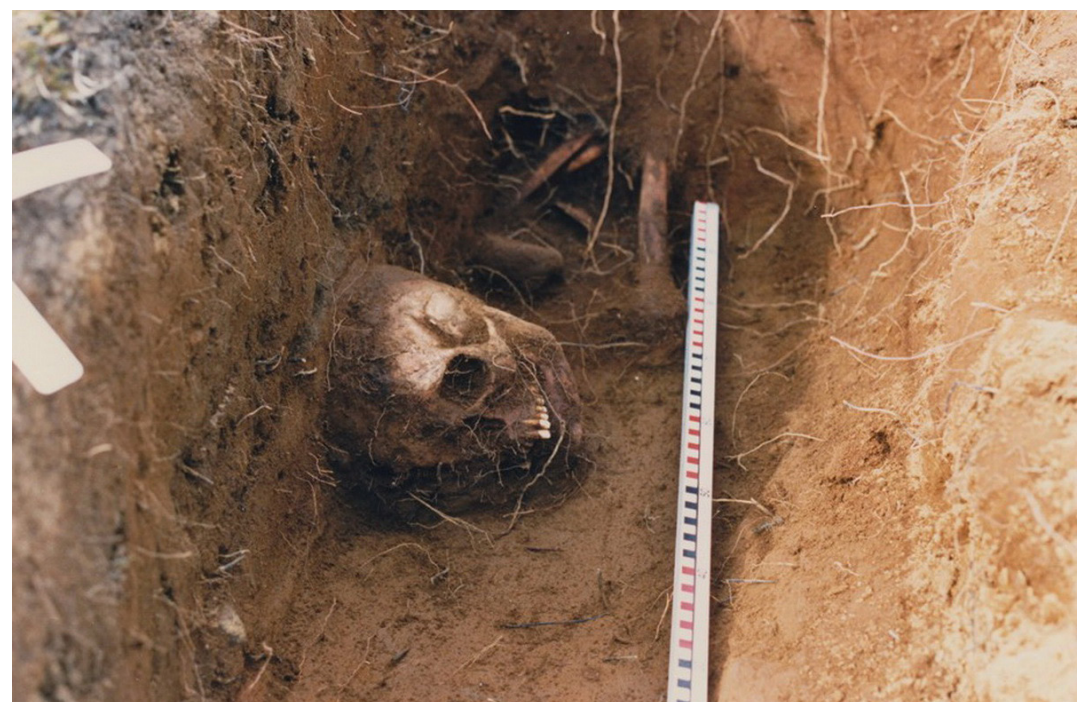

Fig. 5. Grav 1.Kvindens kranium. Det ses tydeligt, at de to fortænder i overkæben manglede. Foto: Lise Gjedssø Bertelsen. 
selve materialet var formuldet. Fortil oven på rygsøjlen fandt vi rester af små hægter til maller af jern på række ned for midten. Nederst i rækken fandtes jernstykker af ca. $1 \mathrm{~cm}$ i tværmål, eventuelt knapper. Der fandtes ingen rester af en kiste uden om eller under liget.

Det, som var mest bemærkelsesværdigt med hensyn til skelettet i grav 1 , var en unormal placering af nogle af knoglerne. Først og fremmest var kraniet trukket så langt bagover, at man skulle kunne tro, at det havde været skilt fra kroppen og derpå lagt ned ved liget. Og på grund af, at graven var så lav, kunne man i begyndelsen derfor ikke udelukke, at kraniet tidligere kunne være dukket op i vejkanten ved en udvidelse af vejen og, at man derfor havde haft det taget op. Men vurdering af kraniet og øverste halshvirvlers position ved professor Jón Steffensen, Háskóli Íslands, og unders $\varnothing$ gelser af profilsnit af jordlagene i graven dokumenterede klart og tydeligt, at der ikke havde været manipuleret med kraniets position siden gravlæggelsen efter, at kvinden var blevet druknet i den nærved liggende å (fig. 5), og en ny indgående analyse af knoglerne har ikke kunnet påvise andet (Walser III 2018: 1-3).

En anden bemærkelsesværdig detalje var, at da skelettet blev gravet frem, så fandt vi kun få af dets tåknogler. Da disse knogler er små, er det ikke helt umuligt at tænke sig, at de uforvarent kan være gravet bort ved undersøgelsen, men det vakte også spekulationer, om de kunne være fjernet ved tortur lige inden henrettelsen? Ved civile retter var tortur af de anklagede forbudt ved lov fra 1537, og forbuddet blev gentaget i Danske Lov af 1683, som tilstræbte retsenhed. En tilståelse afgivet under tortur kunne ikke bruges som bevis i en retssag. Men når en person først var dømt til døden, kunne man derimod godt torturere. ${ }^{3}$ Der findes ingen skriftlige beviser for tortur i Kópavogur-sagen. Ny analyse af knoglerne påviste ingen spor af tortur, men der påpeges, at de fleste tåknogler manglede (Walser III 2018: 1-3).

\section{Grav 2}

Stendysse 2 lå lige nord for grav 1 (fig. 6). Den sås ikke så let umiddelbart på overfladen inden unders $\emptyset$ gelsen, men som allerede påpeget kom stenene frem, så snart den øverste græstørv blev fjernet. Under afrensningen af $\emptyset$ verste stenlag af den oprindelige dysse 2 , det vil sige laget imellem

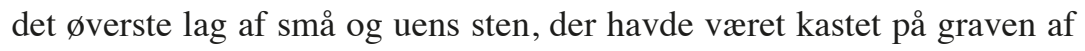

\footnotetext{
${ }^{3}$ Venligst oplyst af arkivar, seniorforsker, dr. phil. Tyge Krogh, Rigsarkivet i København.
} 


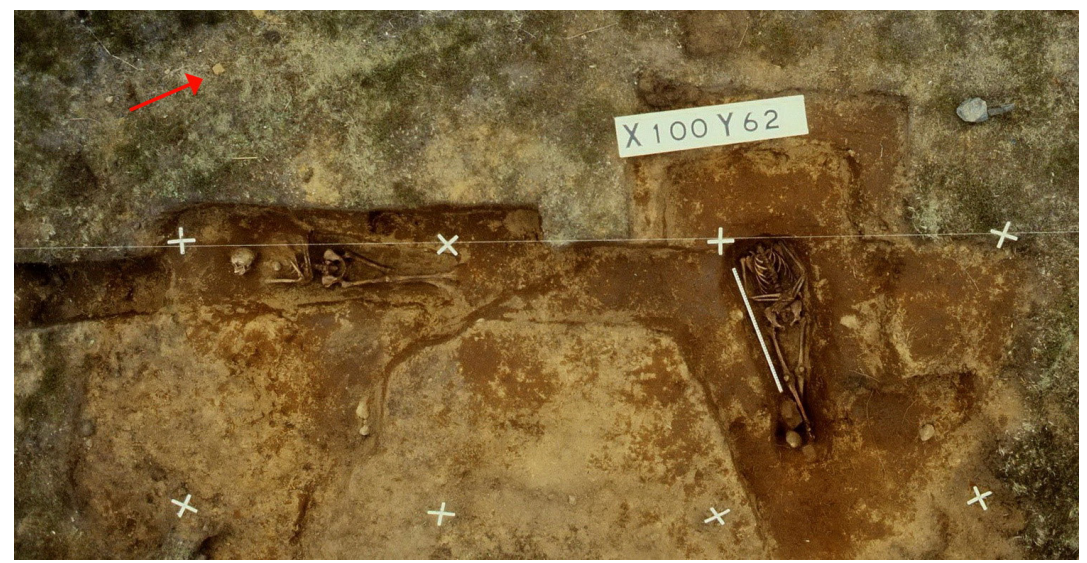

Fig. 6. Grav 1 og 2 med mål og koordinater lagt hen over. Der er to meter mellem krydsene. Foto: Guðmundur Ólafsson.

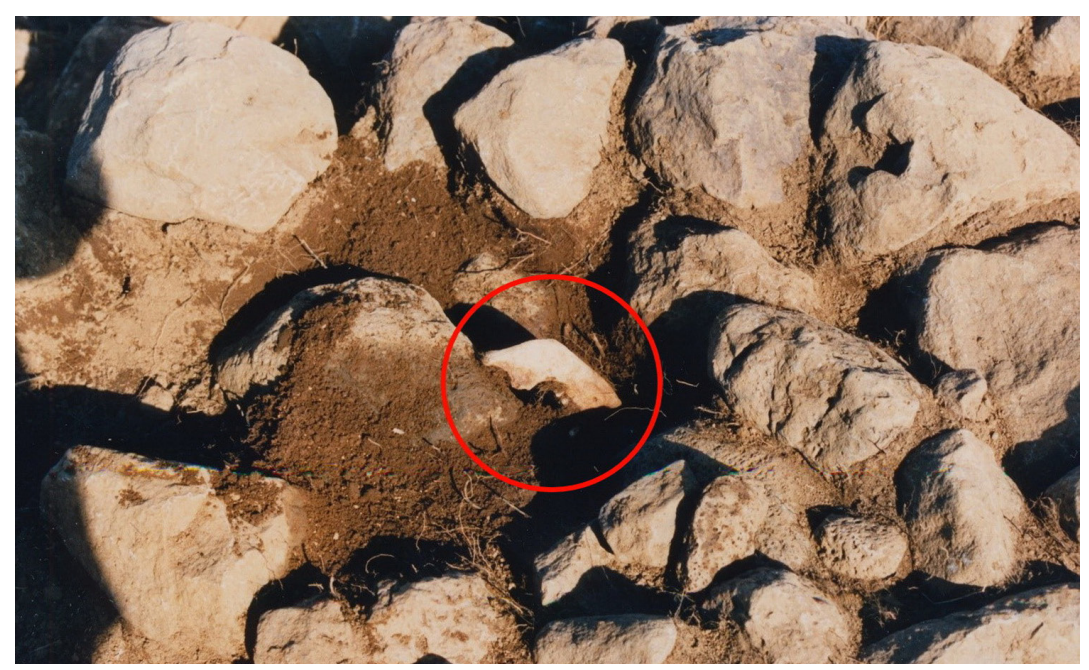

Fig. 7. Underkæbe fra mandskranie in situ oven på øverste oprindelige stenlag af grav 2. Foto: Lise Gjedssø Bertelsen.

vejpasserende senere, og det oprindelige øverste lag af ensartede sten på dyssen, fandtes en underkæbe fra et mandskranie og nogle løse tænder (fig. 7). Umiddelbart derunder fremkom de mange mere ensartede sten, der oprindelig havde afmærket graven, som da havde været 2,5 m × 1,6 m i omrids. Derunder kom flere stenlag. 


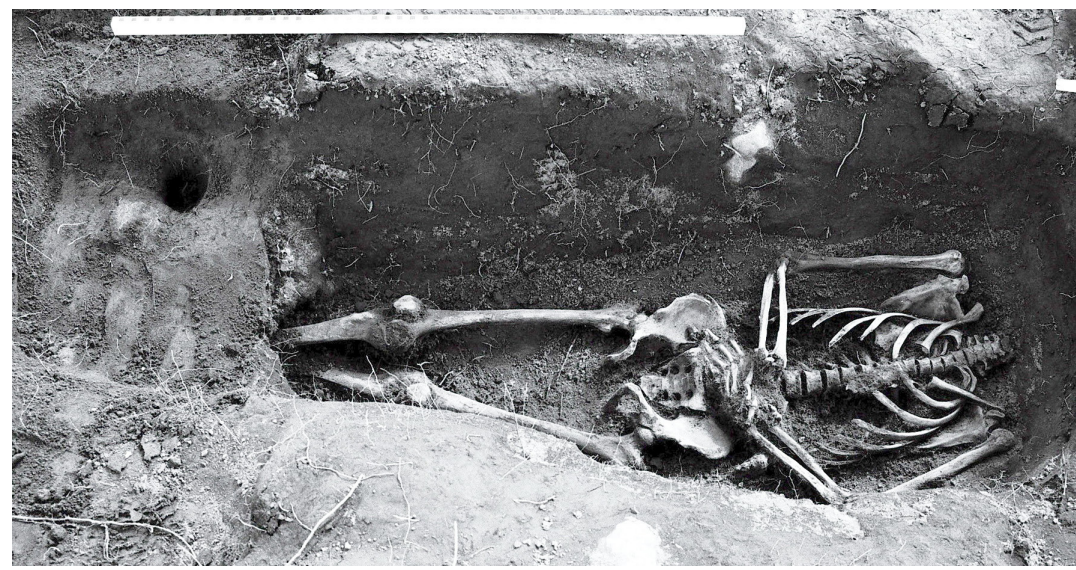

Fig. 8. Skelet af mand i grav 2. Kranie og to og en halv øverste halshvirvler mangler. Ud for mandens højre fod ses hullet efter den stage, som hans hoved har været sat på. Foto: Guðmundur Ólafsson.

Under stendyssen lå skelettet af en mand, som manglede kraniet samt $2 \frac{1}{2}$ af de $\varnothing$ verste halshvirvler (fig. 8). Henrettelsesmetoden havde dermed klart været halshugning. Hænderne lå hen over maven. Benene var korslagte. Ifølge opmåling af mandens lårbensknogler havde han været ca. 1,70 m høj. Graven lå fra nordvest mod sydøst, men målte kun 1,62 m i længde, hvilket viser, at den blev gravet til at passe i længden efter henrettelsen. Graven var ca. $0,7 \mathrm{~m}$ på bredeste sted og tilspidset mod $\varnothing$ st samt $0,4 \mathrm{~m}$ bred ved fødderne. Graven var ca. $1 / 2 \mathrm{~m}$ dyb. I graven fandtes to stykker rødbrunt jern. Det ene stykke lå oven på højre hofte og var eventuelt rester af et spænde eller et remendebeslag. Det andet lå ved venstre hofte. Muligvis var der tale om rester af noget, som havde tilhørt afdødes klædning. Der var heller ingen spor efter kiste i denne grav.

\section{Hoved på stage}

Ud for fødderne sås tydeligt et $9 \mathrm{~cm}$ bredt rundt hul mellem flere sten. Heri havde stået en træstage, ${ }^{4}$ som havde været sat ned i graven som det sidste (fig. 8). Store sten havde været placeret tæt op ad stagen for at

\footnotetext{
${ }^{4}$ Lang træstang/træpæl.
} 
støtte denne. For at virke afskrækkende og ydmygende havde den dødes afhuggede hoved oprindelig været sat på stage oven på graven til offentlig beskuelse til skræk og rædsel for de forbipasserende.

Underkæben, som tidligere var blevet fundet under græstørvslaget, men oven på gravens фverste oprindelige stenlag, må have været del af det kranium, som oprindelig havde været sat på stagen, men som derefter var faldet ned, da denne med tiden var rådnet bort, og/eller bløddele og knogler var forvitrede, så underkæben af kraniet var faldet ned på stendyssen. Så muligvis har underkæben hørt sammen med det kranium, som blev fundet ved vejarbejdet i 1938 .

\section{Hvem var begravet i dysserne?}

Det vigtige spørgsmål var så naturligvis, om vi med udgravningen var nået frem til med sikkerhed at afgøre, hvem de to henrettede mennesker, som var begravet i dysserne ved vejen og åen, var. Længe inden udgravningen havde fundet sted, havde folk jo talt om, at de såkaldte pardysser skulle indeholde Sigurður Arason og Steinunn Guðmundsdóttir. Muligvis kan udgravningens resultater hjælpe os til at få bedre klarhed over dette spørgsmål.

\section{Dødsdomme i Kópavogur}

For at kunne nærme os svar på, hvem der i sin tid var stedt til hvile i de to sammenhørende dysser, måtte vi gå til de skriftlige kilder, som berettede om dødsdomme på Kópavogurs ting (Annálar 1400-1800 I; Jón Espólín 1828 \& 1829; Matthías Pórðarson 1929). Her kunne det fastslås, at mindst 12 dødsdomme var blevet afsagt og eksekveret på Kópavogurs ting, hvor de dødsdømte blev halshugget, hængt eller druknet. Disse 12 dødsdomme og deres forløb skal der her nedenfor gøres kort rede for. Symbolenes betydelse: $\hat{\sigma}=$ mand $q=$ kvinde .

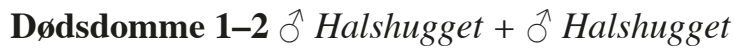

De første dødsdomme, som der er litterært bevis for fra Kópavogurs ting, og som i øvrigt er det ældste nedskrevne bevis for tingstedets eksistens, 
er fra den 1. juni 1523 over Týli Pétursson. Týli, som var forhenværende landshøvding på Bessastaðir, var to gange kommet tilbage til Bessastaðir, havde taget landshøvding Hannes Eggertsson til fange et stykke tid, stjålet penge fra Bessastaðir kirke og stjålet skatte fra kongen. Efter at han var blevet fanget og dømt, blev han ført østen for Bessastaðir, hvor han blev halshugget sammen med sin søn, til et sted, som siden har heddet Týlishóll. Dog vides det ikke, hvor Týlishóll har ligget. Efter beskrivelsen om, at Týli blev ført østen for Bessastaðir, skulle man tro, at der var tale om tunet øst for Bessastaðir, men her er sådanne handlinger aldrig blevet verificeret. Det er derfor muligt, at Týli og søn blev ført til Kópavogurs ting, dødsdømt, henrettet og begravet dér.

\section{Dødsdom 3 $\bigcirc$ Halshugget}

Hinrik Kules var tysker. Han dømtes til døden og blev henrettet på Kópavogurs ting den 23. februar 1582 for at have dræbt Bjarni Eiríksson julenat på Bessastaðir. Det fortaltes, at Hinrik Kules var blevet gravlagt under en dysse øverst på Arnarneshøjden, vest for den gamle vej i en nu overgroet dysse.

Dødsdomme 4-5 $\stackrel{\dagger}{\dagger}$ Halshugget, sandsynligvis $+q$ Druknet, sandsynligvis I Íslands Árbakur (Jón Espólín) siges det, at bøddelen på Bessastaðir, Jón Stengrímsson, fik barn med sin steddatter, og at de blev henrettede i Kópavogur 1636. Hvilken fremgangsmåde, som blev anvendt, fortælles ikke, men sandsynligvis blev han halshugget, og hun druknet ifølge gængs skik og brug. Eftersom kvinden i dysse 1 i Kópavogur var ca. 43 år gammel, og manden i dysse 2 var ca. 26 år, så kan det ikke være denne stedfar og steddatter, som lå begravet i dysserne.

\section{Dødsdom 6 đ Hangt}

Den 25. januar 1664 blev Pórður Pórðarson dømt til døden på Kópavogurs ting for butikstyveri. Hans søster Guðrun appellerede dommen til Altinget i 1665. Men lige lidt hjalp det, for i en note med afskrift af dommen i altingsbogen 1666 står, at Pórður blev hængt.

Dødsdomme 7-8 $\bigcirc$ Hangt + q Haengt

I december 1677 blev en mand og en kone dømt for samme slags tyveri.

Dødsdomme 9-10 $\widehat{\jmath}$ Hangt $+\widehat{\partial}$ Hangt

I 1703 blev to tyve dømt til døden og hængt. 
Dødsdomme 11-12 $q$ Druknet $+\widehat{o}$ Halshugget

Til sidst berettes det, at Steinunn Guðmundsdóttir og Sigurður Arason blev dødsdømt og henrettet på Kópavogurs ting 1704. Dommene faldt 14 . november og blev eksekveret dagen derpå.

Ovennævnte er de eneste 12 domme og henrettelser, som det er lykkedes at finde frem til for Kópavogurs tings vedkommende. Selve Kópavogurs ting blev flyttet til Reykjavík i året 1753, og dermed var dets tid forbi. I den periode, som Kópavogurs ting fungerede, blev fem mænd halshugget (dommene 1-2, 3, 4, 12) og fire mænd hængt (dommene 6, 7, 9, 10), og af kvinderne blev to druknet (dom 5 (sandsynligvis) og 11) samt én hængt (dom 8) (Annálar 1400-1800 I: 451-453, 468-470; Diplomatarium Islandicum IX: 140-142; Alpingisbakur Íslands VII: 8-9; Jón Espólín VII: 90-91; Guðrún Sveinbjarnardóttir 1986: 12-15; Matthías Pórðarson 1929: 2-4, 29-33).

\section{Resumé og resultat}

I grav 1 lå skelettet af en kvinde på omkring 40 år. Overkroppens armes placering var usædvanlig med sammenknyttede hænder, og hovedet var bøjet voldsomt bagover. Professor i medicin ved Háskóli Íslands Jón Steffensen, som undersøgte skelettet, afgjorde, at hverken hovedstillingen eller hændernes krampagtige placering kunne skyldes hængning, men udelukkende drukning, og profilsnit af jordlagene i graven dokumenterede da også, at disse var urørte. Kvinden var blevet druknet i Kópavogurs å med sammenbundne hænder og en sæk trukket over hoved og overkrop. Sækken fjernedes ikke, da hun blev gravlagt.

Kvindens tandsæt var sundt og stærkt, men de to fortænder i overkæben manglede. Kunne det skyldes hårdhændet tortur umiddelbart inden drukningen, hvor en tand er faldet ud, inden sækken blev trukket over hendes hoved og overkrop, mens den anden tand måske først faldt ud herefter og derfor blev fundet i graven? Mere sandsynligt er det dog, at tænderne blev slået ud, da kvinden blev kastet i vandet og, at hun måske slog hovedet mod sten i bunden av bækken. At vi ikke fandt ret mange af hendes tåknogler bestyrkede den mulige teori om tortur lige inden drukningen. Den døde var placeret med korslagte ben, så sækken har kun gået til taljen og ikke indesluttede hele kroppen. Der fandtes ingen rester af kiste. Af 
de 12 verificerede dødsdømte på Kópavogurs ting blev kun én kvinde beviseligt henrettet ved drukning, det var Steinunn Guðmundsdóttir fra Árbær i 1704. Steddatteren fra Bessastaðir (dødsdom 5) blev sandsynligvis også druknet, men det er ikke præciseret i annalen. Hun var efter al sandsynlighed også meget yngre end kvinden i dysse 1 .

I grav 2 lå skelettet af en ung mand i tyverne, der var blevet halshugget, idet hoved og $\varnothing$ verste to og en halv halshvirvel manglede. I følge skriftlige kilder var fem mænd blevet halshugget på Kópavogurs ting: Týli Pétursson og søn i 1523, tyskeren Hinrik Kules i 1582, bøddelen på Bessastaðir i 1636 og Sigurður Arason i 1704. Aldersmæssigt kunne der her ikke være tale om, at den unge mand i grav 2 hverken kunne være Týli Pétursson, der må have været meget ældre, eller hans søn, der må have været gravlagt sammen med faderen. Hvad angår tyskeren Hinrik Kules, skulle han være blevet begravet under en dysse på Arnarneshæð. I følge skriftlige kilder blev kun én mand halshugget på Kópavogurs ting og hovedet sat på stage ved hans grav, det var Sigurður Arason fra Árbær i 1704. Der fandtes ingen rester af kiste.

Dysse 1 og 2 hørte klart sammen. De skriftlige kilder beretter kun om ét par, der sammen dømtes og henrettedes som ovenfor beskrevet: Steinunn og Sigurður fra Árbær i 1704. Resultatet af den arkæologiske udgravning blev, at vi efter al sandsynlighed havde fundet de jordiske rester af de to henrettede Sigurður Arason og Steinunn Guðmundsdóttir. Dog med undtagelse af Steinunn Guðmundsdóttirs ene fortand i overmunden og de fleste af hendes tåknogler samt Sigurður Arasons to og en halv øverste halshvirvler og hans kranie (bortset fra underkæben).

\section{Kópavogur dødsstraffene sammenholdt med nogle danske eksempler}

Under enevælden regerede den danske konge over ikke mindre end Danmark, Norge, Island, Færøerne og Grønland, lige som han var hertug i de tyske områder Slesvig, Holsten og Oldenburg. Kópavogur-tinget er i historien især kendt for, at enevælden, som i 1660 var blevet indført i Danmark-Norge under kong Frederik 3., blev indført på Ísland her den 28. juli 1662. Af relevans for Kópavogur problematikken vil der her nedenfor blive givet nogle eksempler på domsafsigelser og henrettelser i Danmark.

Knibning med gloende tænger indgik i straffelovens forordning af 
1697 som en mulig del af skærpelse af straffe for grove mord i Danmark (Kragh-Nielsen 2018: 222). På den dømtes sidste vej fra arrest til rettersted blev morderen derfor af skarpretteren knebet først på selve gerningsstedet, så på vejen videre frem til retterstedet og til sidst også dér. Knibning med gloende tænger var en del af et barbarisk straffesystem udført med grusomhed mod delinkventen, en specifik tortur med store fysiske og psykiske smerter til følge.

Straffen knibning med gloende tænger praktiseredes også på Ísland i 1700-tallet og 1800-tallet (Alpingisbaekur Íslands XVI: 483, 489-491; XV: 340-341; Annálar 1400-1800 IV: 631, 164; V: 195, 302, 323).

På Nationalmuseet i København er bevaret en $76 \mathrm{~cm}$ lang metaltang udstyret med henholdsvis tre og to krumme kløer, der i lukket stand griber ind i hinanden. Tangen er fra Kolding, blev sidste gang anvendt i $1753 \mathrm{og}$ indleveret på Nationalmuseet i midten af 1800-tallet (afbildet hos Gregersen 2018: 30; Kragh-Nielsen 2018: 222). Og med hensyn til eventuel tortur umiddelbart før døden var der som tidligere beskrevet for Steinunns vedkommende spørgsmålene om de manglende tæer samt fortænder i overmunden. De seneste analyser af knoglerne har imidlertid sat en stopper for sådanne spekulationer og påvist, at kvindens fortænder var på plads, da hun blev lagt i graven og, at de sandsynligvis er faldet ud senere under nedbrydelse av krop og jordlag (Walser III 2018, personligt oplyst).

Fra begyndelsen af 1500-tallet og frem til begyndelsen af 1800-tallet var de såkaldte skillingstryk eller skillingsviser om forbrydelser og henrettelser med et træsnit som forsideillustration populære. De udkom op til voldsomme begivenheder som for eksempel eksekveringer af dødsdomme og beskrev dramaerne naivt og bloddryppende. Et sådant træsnit på forsiden af en skillingsvise fra 1727 om tre rovmordere præsenterer stadier i deres grusomme afstraffelse (Krogh 2000: 571, bilag D, vise nummer 1727:1 og sidste illustrationsside $\varnothing$ verst). Bagest til venstre i dette billede ses den ene af de dømte siddende $\mathrm{i}$ en vogn, mens han bliver knebet $\mathrm{i}$ armen med gloende tænger, og røgen fra det brændende kød står lige op i vejret. Og i baggrunden står fyrfadet til de gloende tænger. En skillingsvise om Thomas Thomasen, med tilnavnet Bisp, jf. herunder, er i dag på Det Kongelige Bibliotek, København (Jerver 1980: 56 ff.).

Knibninger med gloende tænger var hyppige i Danmark. Det gjaldt for eksempel for Henning Andersen i Køng. Han blev henrettet med sværd ved Kiste/Kerte? Bro på Fyn den 3. juni 1704 for at have myrdet sit lille barn. Men kongen modererede hans dom på sådan vis, at hans legeme 


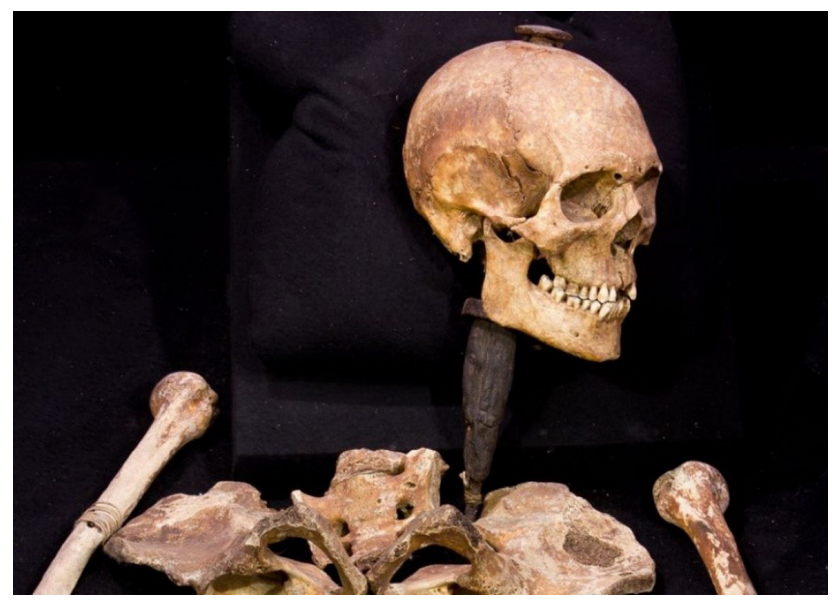

Fig. 9. Thomas Thomasen Bisps kranium gennemnaglet med en kraftig jernspiger samt også nogle af de øvrige knogler fra hans skelet. Han var født 1780. De bevarede skeletdeles genstandsnummer Vendsyssel Historiske Museum 14563 \& journalnummer 040/1983. Foto: Vendsyssel Historiske Museum.

samt afhuggede hoved og hånd kom i kiste og blev begravet på Køng kirkegård (Kragh-Nielsen 2018: 150). Og i 1706 blev Hans Jensen, ligeledes Køng, knebet fem gange med gloende tænger, hvorefter han blev henrettet ved Glamsbjerg Mølle. Han havde myrdet sin kone med et bræt (Kragh-Nielsen 2018: 117). Men mest kendt er Hjørrings sidste henrettelse på galgebakken i Hjørring Bjerge i Vendsyssel den 22. juli 1822 af gårdmand i Sønder Økse Thomas Thomasen, med tilnavnet Bisp.

\section{Mordet i Sønder Økse, Brovst sogn, Vendsyssel, Nordjylland}

22. juli 1822 tidligt morgen blev den 42årige gårdmand Thomas Thomasen, med tilnavnet Bisp, henrettet på Galgebakken i Hjørring Bjerge i Vendsyssel for mord på sin hustru igennem 16 år Maren Justdatter (fig. 9).

Thomas havde først været gift med Margrethe Marie Sørensdatter, med hvem han havde fået et barn, men Margrethe Marie døde kort tid herefter. Senere blev han gift med Maren Justdatter, med hvem han havde været gift omtrent 16 år og havde fået flere børn. Thomas havde ført et retskaffent liv og været en hyppig kirkegænger (måske deraf tilnavnet Bisp?), lige indtil han og en 24årige tjenestepige på gården Ane Mar- 
grethe Christensdatter forelskede sig i hinanden, og hun tilskyndede ham til at forgive sin svagelige kone således, at hun selv kunne blive gift med Thomas. Der var altså her tale om en kærlighedskonflikt i form af et trekantsdrama, hvilket også var tilfældet i Kópavogur sagen.

Forløbet så ud som følgende (Jerver 1980):

18. juni 1821 gav Thomas sin kone et stykke brød med rottekrudt, det vil sige arsenik, gemt under et lag smør. Maren blev derpå meget syg med mavesmerter og opkastninger.

23. juni 1821 døde Maren.

28. juni 1821 blev Maren begravet på Brovst kirkegård.

3. juli 1821 tilstod Thomas under forhør at have forgivet sin hustru på opfordring af Ane Margrethe. Thomas tilstod mordet. Ane Margrethe tilstod at have tilskyndet Thomas dertil. De angrede begge. Uddrag af Øster og Vester Hanherreders Justitsprotokol for dagen beretter, at både Thomas og Ane Margrethe under forhør fremstod "uden bånd og tvang" (Jerver 1980, s. 9 \& 14).

3. november 1821 afsagdes dødsdommen over Thomas. Den lød som følger: "Kendes for ret. Tiltalte Thomas Thomasen Bisp, nu i Hjørring Arrest, bør af skarpretteren at knibes med gloende tænger, først uden for huset i Sønder Økse i Brovst Sogn, hvor han har dræbt sin hustru Maren Justdatter - tre gange mellem dette og retterstedet og til sidst på retterstedet, - dernæst den højre hånd ham levende afhugges med en økse og derefter hovedet ligeledes med en $\varnothing \mathrm{kse}$, hvorpå legemet lægges på stejle, og hovedet tilligemed hånden at sættes på en stage over legemet" (Jerver 1980: 45). Thomas Thomasen Bisps resterende knogler blev i 1978 undersøgt af dr. J. Balslev Jørgensen ved Universitetets Anthropologiske Laboratorium i København. I redegørelsen står blandt andet om halshvirvelsøjlen, at den mangler totalt, hvilket også gør sig gældende for knoglerne af højre hånd. ${ }^{5}$

22. juli 1822 eksekveredes dødsdommen på galgebakken i Hjørring Bjerge tæt ved vejen mod Skagen. Den dødes krop og hoved blev sat på hjul og stage. Skarpretter var Jochum Henrik Stengel af Odense (Jerver 1980: 59).

Men allerede kort tid efter blev liget (på hjul og stejle) fjernet og begravet i en nærliggende bakke, hvor det lå uforstyrret i 78 år. Vendsyssel Historiske Museums historisk arkiv ejer notatbogen, hvori både henrettelsen og bortfjernelsen af liget beskrives.

3. oktober 1900 fandt arbejdere under sandgravning Thomas' skelet

\footnotetext{
${ }^{5}$ Vendsyssel Historiske Museums genstandsnummer 14563 og journalnummer 040/1983.
} 
inklusiv det gennemnaglede kranium. De bevarede skeletdele samt jernspigeret har siden tilhørt Vendsyssel Historiske Museum med genstandsnummer VHM 14563 og journalnummer 040/1983.

Tjenestepigen Ane Margrethe kom i Viborg Tugthus på livstid dog først efter, at hun i Hjørring arrest at have født en datter, som hun udlagde Thomas som far til. Ane Margrethe blev benådet i 1840.

Til sidst skal nævnes Nationalmuseets arkæologiske udgravninger i midten af 1940erne af Slots Bjærgby Galgebakke på bakkedraget ved Slots Bjærgby lidt syd for Slagelse på Sjælland (Glob 1947: 38 ff.). Her blev der fundet rester af over 30 delinkventer, hvoraf mange var 18-30årige kvinder, nedkulet ca. en meter under grønsværen (KraghNielsen 2018: 262). Flere kranier var spigrede (Kragh-Nielsen 2018: 263, foto). En halshugget med stejlet kranium lå på brystet med det afhuggede hoved imellem benene (Glob 1947: 41, fig. 4; Gregersen 2018: 174; Kragh-Nielsen 2018: 146).

\section{Sammenfatning}

Udgravningen af de to henrettedes gravhøje på Kópavogurs ting er den eneste af sin slags hidtil udført i Ísland, den er derfor af særlig værdi. Mange symbolske tegn kan læses ud af begge begravelser. Henrettelse er eksekvering af en afsagt dødsdom i følge tidens love; det er samfundet, som straffer den kriminelle person dels som hævn for, hvad han eller hun har forbrudt sig imod, dels med det formål at afskrække andre mennesker imod at begå lignende lovovertrædelser. Henrettelse på den tid var et juridisk religiøst ritual bestående af tre faser: oplæsning af dommen, præstens tale og skarpretterens arbejde. Hovedaktører var selvsagt den anklagede og bøddelen, men hertil kom $\varnothing$ vrighedspersoner repræsenterende loven og kirken. Bøddelen havde undertiden en eller flere hjælpere med, såkaldte natmænd, til for eksempel at samle det afhuggede hoved op, sætte det på stejle etc. Vi ved, hvem de juridiske $\emptyset$ vrighedspersoner ved Sigurður og Steinunns endeligt var, men ikke hvem den gejstlige $\varnothing v$ righedsperson var, dog er det tænkeligt, at det kan have været Pórður Konráðsson, præst ved den sognekirke, som både Sigurður og Steinunn tilhørte, han som tidligt i dramaets forløb havde prøvet at forsvare Sigurður. Den gejstlige skulle berede den dømte til døden og sikre, at han forlod denne verden angerfuld og med en tro på den almægtige gud (Gregersen 2018: 197). 
Navnet på bøddelen, som udførte henrettelserne i 1704, kommer intetsteds frem i de skriftlige kilder, som vi har fundet, og eftersom domsprotokollen ikke eksisterer længere, så kan det synes en umulig opgave at finde ud af, hvem han var. Men år 1703 blev der foretaget en folkeregistrering på hele Ísland, og deraf fremgår, at der da fandtes seks bødler på Island. Så sandsyligvis er det en af dem, som udførte henrettelserne i Kópavogur år 1704. På sydvest Ísland fandtes der to bødler. Den ene var 40 år gammel og boede i Rosmhvalahreppur yderst på Reykjanes. Den andre var Porsteinn Ottason. Han var 42 år gammel og boede i Seltjarnarnes. Af folkeregisteret fremgår, at han var bøddel for sysselmanden i Kjósarsýsla. Og eftersom det var sysselmanden i Kjósarsýsla, som først gjorde opmærksom på sagen og skrev til amtmanden, og fordi det siden var sysselmanden i Seltjarnarnes, som arresterede Sigurður, kan man ganske let konkludere, at det var Porsteinn Ottason, som stod for henrettelserne i Kópavogur 1704.

Differentierede henrettelsesmetoder i tiden afspejler både selve forbrydelsens art såvel som delinkventens status i sit samfunds sociale lagdeling samt køn. Steinunn og Sigurður blev begge dømt til døden for mordet på hendes ægtefælle efter devisen, som vi kender den fra Gamle Testamente og Moseloven, Guds lov. ${ }^{6}$ Den midaldrende Steinunn var en gift bondekone, så hendes sociale position var højere end den unge Sigurðurs, der ernærede sig ved fiskeri. Fordi hun var kvinde, blev hun som straf druknet i Kópavogurs å; de fleste drukningsstraffe på Ísland blev eksekveret i "Druknepølen" på Pingvellir, hvor man har belæg for, at mindst 18 kvinder blev druknet (Már Jónsson 2016).

Sigurður, som var en jævn mand, blev halshugget med en økse, må vi formode. Sigurðurs hoved blev sat på stejle på hans grav, men da vi udelukkende fandt hans nedfaldne underkæbe (fig. 7) og ikke det $\varnothing v$ vige af kraniet, ved vi ikke, hvorvidt der var tale om en jernspiger, som var hugget ned igennem kraniet og hjernen ned i stejlen, der var rejst på retterstedet, som der findes eksempler på i Danmark (fig. 9), eller blot, at træpælen, som var $9 \mathrm{~cm}$ i diameter længst nede, blev tilspidset i toppen og stukket op igennem halsen ind i kraniet og hjernen. Sidstnævnte forekommer mest sandsynlig, for hvis det kranie, som vejarbejdere i 1938 fandt, vitterligt var Sigurðurs, så nævnte disse mænd udelukkende som kendetegn, at det havde meget hår. Rester af en eventuel jernspiger havde de umuligt kunne overse.

\footnotetext{
6 https://natmus.dk/historisk-viden/danmark/enevaelde-1660-1848/den-enevaeldige-stat/ enevaeldens-strafformer/
} 
Men også selve måden, hvorpå en henrettet blev begravet, er afslørende, for den skulle passe til de forestillinger, som herskede i samtiden om menneskets skæbne hinsides livets afslutning. At ende i afretterstedets uindviede jord var slemt, og her var forskellen imellem Steinunn og Sigurðurs graves orientering påfaldende. Steinunn fremprovokerede mordet, og hendes grav var anlagt i nordnordøst-sydsydvestlig retning altså i direkte modstrid mod normen for kristne graves $\emptyset$ st-vest vendte orientering, hvor den afdødes hoved er i vestenden således, at vedkommende på opstandelsens dag vendt imod øst kan møde Kristus, som kommer fra solopgangens verdenshjørne. Dette afspejler muligvis, at Steinunns forbrydelse ansås for størst eller, at hun ikke havde angret i lige så høj grad som han, hvorfor hun dermed ikke synes at have store chancer for at komme i paradiset. Sigurður udførte drabet, men hans grav var anlagt i øst-vestlig retning, altså i overensstemmelse med kristen gravskik således, at han måske havde udsigt til at komme i paradiset. Øvrighedspersonerne var alle mænd, så hvorvidt misogyni tillige har spillet en rolle angående Steinunns endeligt kan vel ikke udelukkes.?

Udvidelsen af Hafnarfjörðurs vejen ved Kópavogurs å med deraf følgende arkæologisk undersøgelse af de to gravhøje viste, at vi her havde at gøre med en gammel retssag, og der blev kastet nyt lys på de to kriminelle personer Sigurður Arason og Steinunn Guðmundsdóttirs skæbne samt dramatiske og grusomme straf for mord, som blev håndhævet her i 1704 for mere end 300 år siden. De bevarede skeletdele fra udgravningen tilhører Pjóðminjasafn Íslands/Islands Nationalmuseum med inventarnummer PJMS 1988-132 (skelet 1) og PJMS 1988-135 (skelet 2).

\section{Kilder og referencer}

Alpingisbakur Íslands V, VII, X. 1944-1969. Reykjavík: Sögufélag. Annálar 1400-1800. 1922-1988. Reykjavík: Hið íslenzka bókmenntafélag.

Árni Magnússon, 1955: Chorographica Islandica. Safn til sögu Íslands og íslenzkra bókmennta að fornu og nýju. 2. flokkur, 2. hefti. Reykjavík: Hið íslenzka bókmenntafélag.

Árni Óla, 1943: Árbæjarmálið. I: Lesbók Morgunblaðsins 24.10.1943. S. 445448.

\footnotetext{
${ }^{7}$ Misogyni betyder 'kvindehad, fordomme over for kvinder'.
} 
Bogi Benediktsson, 1909-1915: Sýslumannacefir eptir Boga Benediktsson á Staðarfelli með skýringum og viðaukum eptir Hannes Porsteinsson. IV. bindi. Reykjavík: [s.n.]

Diplomatarium Islandicum, Íslenzkt fornbréfasafn IX. 1909-1913. Reykjavík: Hið íslenzka bókmenntafélag.

Einar Laxness, 1985: Bessastaðir. I: Landið pitt Ísland. Lykilbók. Reykjavík: Örn og Örlygur.

Glob, P.V., 1947: Slots Bjærgby Høje. I: Fra Nationalmuseets Arbejdsmark 1947. S. 38-48. København: Gyldendalske Boghandel - Nordisk Forlag.

Gregersen, Hans, 2018: Det sidste skridt. Danske dфdsdomme gennem 500 år. Turbine.

Guðmundur Ólafsson, 1996: Sakamannadysjar í Kópavogi. I: Lesbók Morgunblaðsins 23.3.1996.

Guðrún Sveinbjarnardóttir, 1986: Rannsókn á Kópavogspingstað. Kópavogur: Kópvogskaupstaður.

Helgi M. Sigurðsson, 1995: Morð við Skötufoss. I: Lesbók Morgunblaðsins 21.10.1995.

Jerver, Mogens, 1980: Mordet i Sønder Økse. Borgen.

Jón Árnason, 1954: Íslenzkar pjóðsögur og avintýri I. Reykjavík: Bókaútgáfan Pjóðsaga.

Jón Espólín, 1828 \& 1829: Íslands Árbakur í sögu-formi VII. Kaupmannahöfn.

Kragh-Nielsen, Niels H., 2018: Straffet på livet. Henrettelser i Danmark 15371892. Gads Forlag.

Kristján Eldjárn, 1982: Örnefni og minjar í landi Bessastaða. I: Árbók hins íslenzka fornleifafélags 1981. S. 132-147.

Krogh, Tyge, 2000: Oplysningstiden og det magiske. Henrettelser og korporlige straffe i 1700-tallets første halvdel. Samleren.

Matthías Pórðarson, 1929: Nokkrar Kópavogs-minjar. I: Árbók hins íslenska fornleifafjelags 1929. S. 1-33.

Már Jónsson, 2016: Hversu mörgum konum var drekkt í Drekkingarhyl og fyrir hvað? Visindavefurinn 29.6.2016. Hentet den 31.1.2019. http://visindavefur.is/ svar.php?id=72129.

Nationalmuseet. [Uden år]. Enevaeldens strafformer. Hentet den 12.4.2019. https://natmus.dk/historisk-viden/danmark/enevaelde-1660-1848/denenevaeldige-stat/enevaeldens-strafformer/

Páll Sigurðsson, 1984: Athuganir á framkvæmd líflátshegninga og á aftökustöðum og aftökuörnefnum á Íslandi. Erindi og greinar 11. Reykjavík: Félag áhugamanna um réttarsögu.

Walser III, J. W., 2018: Collections report on human remains from Kópavogur (KOV-A-1 and KOV-A-2). National Museum of Iceland. Unpublished report.

Pjóðskjalasafn Íslands, Manntalsvefur. http://manntal.is/leit/böðull/1703/1/1703. Hentet den 24.1.2019. 


\section{Summary}

Two shallow graves of executed persons in Kópavogur

In September 1704 a man named Sæmundur Pórarinsson was murdered by the river Elliðaá (fig. 1). Steinunn Guðmundsdóttir, his 43-year old wife, and SigurJur Arason, a 26-year-old man who lived with his mother, had had an affair and when Sæmundur was found dead in the river, rumours arose that he had been murdered. Sigurður was arrested for the murder. He first denied all allegations, but eventually he confessed and said that Steinunn had urged him to kill her husband. On November $14 t^{\text {th }}$ they were both sentenced to death at Kópavogur's assembly and executed the following day. He was beheaded and his head put on a stake. She was drowned. Both were buried in unconsecrated ground on the opposite side of the road (fig. 2).

In the spring of 1988, the archaeologists Guðmundur Ólafsson, Lise Gjedss $\varnothing$ Bertelsen and Sigurður Bergsteinsson excavated their remains.

The excavation uncovered a pair of barrows (fig. 3). A lot of small stones had been thrown on top of the original layer by passers-by, a custom which prevented revenance according to Icelandic folklore.

Grave 1. Under the pile of stones, in a shallow grave, with no traces of a coffin, lay the skeleton of a woman (figs. 4-6). Her legs were crossed, and most of the bones from the toes were not found. The left arm was slanted down towards the stomach, the right arm inclined up towards the chest. The fists were clenched. The skull was in a strange distorted position. Two cervical vertebrae lay outside normal position, and the two front upper teeth were missing, but one was found in the grave behind the skull. She had been drowned with a sack covering her upper body. Although the missing toes and teeth raised the suspicion of torture, there is, no written evidence of torture in Kópavogur and by civil law, torture of the accused, but yet not convicted was banned and recent analysis showed no signs of torture. A confession given under torture could not be used as evidence in a lawsuit, however, when a person had been sentenced to death, he or she could be tortured, as an addition to the punishment in Denmark as well as in Iceland.

Grave 2. On top of the second pile of stones a lower jaw of a man's skull was found and some loose teeth, the grim remains of the skull that had been placed on a stake, and eventually fallen down (fig. 7). In a shallow grave under the stones lay the skeleton of the beheaded man (figs. $6 \& 8$ ), with the skull and the upper $2 \frac{1}{2}$ cervical vertebrae missing. The legs were crossed (figs. $6 \& 8$ ). By his feet was a $9 \mathrm{~cm}$ wide round hole for the stake, supported by several stones. The decapitated head had been placed at the top of the stake to intimidate passers-by on the road (figs. $6 \& 8$ ). There were no traces of a coffin.

From literary sources we know that at least 12 death sentences were carried out at Kópavogur's assembly. The last one was carried out in 1704 over Steinunn and Sigurður in accordance to Icelandic law. 
The Kópavogur gravesite is the only excavated execution site in Iceland, but comparable cases have been found in Denmark, such as one from 1822. Thomas Thomasen Bisp was executed in Vendsyssel for the murder of his wife Maren Justdatter. He had an affair with his maid Ane Margrethe Christensdatter and poisoned his wife. Thomas was sentenced to death by beheading and penalty on wheels and steep. Thomas's body, including the head pierced by an iron nail, was soon removed and buried in a nearby hill, where it lay undisturbed for 78 years until road workers discovered it (fig. 9). Then the bones came at Vendsyssel Historical Museum. Ane Margrethe was sentenced to lifelong work detention in Viborg Prison, but after many years she was pardoned.

Keywords: Sakamannadysjar í Kópavogi/Hjónadysjar; Henrettet par i dobbeltgravhøje i Kópavogur, Ísland; Kópavogur, excavation, Iceland; graves, skeletons, murder; execution of death sentences; punishment methods; death penalty by drowning, beheading and wheels and steep.

Guðmundur Ólafsson

Pjóðminjasafn Íslands/Islands Nationalmuseum

ORCID iD 0000-0001-6284-3773

\section{Lise Gjedss $\phi$ Bertelsen}

Marie Curie Research Fellow 2012-2014, Uppsala universitet

ORCID iD 0000-0002-5719-5481 



\title{
Sjö plánetur í ljóðmaelum Ein isländisches Gedicht über die Planetenkinder \\ Mit einem Exkurs: Kritische Anmerkungen zur \\ Laienastrologie und Laienphilologie
}

\author{
HUBerT SEELOW
}

\section{Einleitung}

In dem in der isländischen National- und Universitätsbibliothek aufbewahrten Manuskript JS 392 8vo, entstanden um die Mitte des 18. Jahrhunderts, findet sich neben zahlreichen anderen Texten ${ }^{1}$ auch ein Gedicht über die sieben Planeten (Bl. 13v-15r). Der Gedichttext besteht aus sieben Abschnitten (für die sieben Planeten), die jeweils durch eine zentriert plazierte Überschrift aus Planetennamen samt zugehörigem Symbol gekennzeichnet sind. Die Abschnitte für Saturn, Jupiter, Mars, Sonne, Venus und Merkur - in dieser Reihenfolge - bestehen aus je zwei Strophen, der abschließende Abschnitt für den Mond umfaßt drei Strophen. Innerhalb der sieben Abschnitte ist der Text fortlaufend geschrieben, doch ist zwischen den Strophen innerhalb eines Abschnitts jeweils eine kleine Lücke frei gelassen, um den Beginn einer neuen Strophe zu markieren. Die Gedichtüberschrift, die Überschriften der sieben Abschnitte sowie die Strophenanfänge (sowie die letzte Textzeile, die als Hurenkind oben auf einer neuen Seite des Manuskripts steht) sind durch die Verwendung einer Kanzleifrakturschrift ausgezeichnet, während sonst eine für das 18.

${ }^{1}$ Zum Manuskript JS 392 8vo und zu den darin überlieferten Texten siehe Páll Eggert Ólason 1927: 693, sowie https://handrit.is/en/manuscript/view/is/JS08-0392

Seelow, Hubert. 2019. Sjö plánetur í ljóðmaelum: Ein isländisches Gedicht über die Planetenkinder. Mit einem Exkurs: Kritische Anmerkungen zur Laienastrologie und Laienphilologie. Scripta Islandica 70: 61-86. 
Jahrhundert in Island typische Kurrentschrift verwendet ist; die Gedichtüberschrift, die Überschriften der Abschnitte sowie die Anfänge der Abschnitte sind zudem durch die Verwendung von mehr oder weniger kunstvoll verzierten Initialen markiert.

\section{Transkription nach der Handschrift und normalisierter Text des Gedichts}

In einer zeilengetreuen Transkription, bei der die Abkürzungen und verkürzten Schreibweisen des Manuskripts aufgelöst und durch Kursivierung kenntlich gemacht sind (sowie die Zeilen durchnumeriert wurden), lautet der Text des Gedichts folgendermaßen:

1 Siø Planetur i Liödmælumm

Saturnus. $\hbar$

Børn saturnj bornu, breid herdud seint

Reidast, pun $n$ hærd po giefa annars, pióf

5 lind døch ur höfe, nas vyd bäg ad bro sa, bleikleit, stor eigd Reika, brun syd ein sier una, otru veik til föta, Høfud krÿnglott hafa, hærur snemma færa, klar ej klæde bera, kvenna äst skialldan brenner, hugar hafa trega, heimuglega ad geima,

10 laung $\mathrm{j}$ lundar punga, liot med elle möte

Juppiter. 2 .

Juppiter skyrre skipun skinugre børn hinum, Eigd vel eru än ligdar, audug med eimen Raudan, tølug trigd mä hæla, tennur breidar j enne syd hæ

15 rd sann leik virda, sinnis hÿr parft vinna, Frydur medal madur, mikill bryrn værn pikist, slyngur slægur j øngu, sliett nef limer Retter katur krynglu le itur, kurteis Eingen furtur, lifer vel nar æfe, osna udur til dauda.

20 Mars. $\delta^{\top}$

Marz børn Reiklind Röla Reide giørn frid eida, mun $n$ vÿd aflängt Enne Jnn eigd hefnda minnast, orku og af bragds verkum östødugt pau hroosa, svefnug svip pung Jafnan, sol brend ute ef Rőla

25 Lang hardleitur geingur, lyka eru tennur slykar, mi ndad nef so munde, mein er ad vera einum, strakur 
stundar mikid, storlega yllt ad verka, æde andlits

Raudur alldurs mikill skialldann,

Sool $\odot$

30 Solbørn sannleik mæla, svørt eigd hrein i

hiarta, leina lits äsionu løgud breid $o g$

føgur, kyn $n$ bein krÿnglött Enne, kladugur vitur

Radur mislind mäta naser, miuk Rødd fagur bukur.

medal munnur Raudur, madur biugnefiadur, bÿr med

35 burgeis herrum brennur af astum kvenna, ut vill al

ld $u r$ lata, aller halfan $n$ kalle fær po forløg Ry

re, frid $\mathrm{j}$ dauda midium $m$.

Venus. $\$$

Veneriz børnen vænu, viela lauz po spielin $n$

40 snøgg lind snudug higgen, snareigd diørf j

svare, sam brynd syd har kemba, sen $n$ med fa

llegt Enne, giøful hyr j hófe hrosan annarz kiosa.

miøg eru føl og føgur farfe hvytur parfur holl og heilrad

$\varnothing$ llum harid stiörna klaru, syngia semia streinge glød j

45 danse kveda, burdug ber til orda blyf hin oskyr

lyfu

Mercurius ф্ఛ

Mercurj margirku, meina ej børnin einu

$\emptyset$ rt hin andlitz svørtu, enne miött klofnar tennur,

50 laung um legge og fyngur, liett en $n$ naser sliettar, va

rastor syd børnen, bernsk j Rædu feskre.

mälarar miøg sier hæla, mikid opt predika, ac

kta u $m$ afbragds spegter, yfer lesa $o g$ skrifa, styla

ä stiørnu hiöle sinder manna grunda, dikta mæl

55 sku nækter, menn j prötta kennast.

Luna. $\mathbb{~}$.

Luna børn med läne, lit Raud let sier hrosa

mirker mikid verka, matast vel ligd hata, sidlat, sti

llt po neita, sann Reind upp ä gaman, listug lyta ge

60 ste liödast polen möder. Vid Tungl vaxid

fædast, vyd førul öskegg sÿdu, ødrum hrä en eida, audug peirra braude, stødug lytt um leide, $o g$ ä lä de $o g$ siö peim badum, sidugur sifiar tÿdum, syd eru løt $o g$ kvyden. skal med skerding telia skickunar

65 Jlla giche, dära og dreinge öhyra, sem dæmast purfa j næme, firer list ef lærer lagast margur gagur, hæ rdur higgen $n$ firdar han $n$ ölucku pannen $n$. 
In normalisierter isländischer Orthographie, mit normalisierter Zeichensetzung und in Verszeilen angeordnet (sowie - der Übersichtlichkeit wegen - mit einer Strophennumerierung in eckigen Klammern versehen) sieht der Text dann folgendermaßen aus: ${ }^{2}$

\section{Sjö plánetur í ljóðmælum Die sieben Planeten in Versen}

\section{Satúrnus. $\hbar$}

[1] Börn Satúrni bornu, breiðherðuð, seint reiðast, punnhærð, pó gefa annars,

pjóflynd, dökk úr hófi,

nasvío, bág að brosa, bleikleit, stóreygð reika, brúnsío, ein sér una,

ótrú, veik til fóta.

[2] Höfuð kringlótt hafa, hærur snemma færa, klár ei klæði bera, kvennaást sjaldan brennir, hugar hafa trega heimuglega að geyma, löng í lundarpunga, ljót með ellimóti.

Júpíter. 2

[3] Júpíter skýrri skipun skynugri börn hinum, eygð vel, eru án lygðar, auðug með eiminn rauðan, tölug, tryggð má hæla, tennur breiðar í enni, síðhærð, sannleik virða, sinnishýr, parft vinna.

[4] Fríður meðalmaður, mikill, brýnvænn pykist,
Saturn. $\hbar$

Die Saturn geborenen Kinder, breitschultrig, werden nicht leicht zornig, haben lichtes Haar, verschenken aber anderer Gut, diebisch veranlagt, über alle Maßen dunkel, großnasig, lächeln selten, bleich aussehend, gehen großäugig umher, mit herabhängenden Augenbrauen, fühlen sich alleine wohl, treulos, schlecht zu Fuß.

Haben einen runden Kopf, bekommen früh graue Haare, tragen keine saubere Kleidung, entbrennen selten in Liebe zu Frauen, bewahren heimlich traurigen Sinn, lang in Schwermut, häßlich mit Zeichen des Alterns.

Jupiter. 2

Jupiterkinder nach deutlicher Weisung aufgeweckter als andere, mit schönen Augen, sind frei von Lüge, reich an rotem Feuer [=Gold], redselig, ihre Treue ist zu loben, breite Zähne im Gesicht, langhaarig, schätzen die Wahrheit, mit frohem Sinn, vollbringen Nützliches.

Ein schöner Mensch mittlerer Größe, tüchtig, gilt als gutaussehend,

${ }^{2}$ Die Übersetzung ist nur als Verständnishilfe gedacht und verzichtet darauf, metrische Feinheiten wie Stab- und Binnenreime im Deutschen nachzuahmen. Sie bleibt möglichst nahe am Ausgangstext und versucht, ihn Wort für Wort bzw. Zeile für Zeile wiederzugeben. 
slyngur, slægur í engu, slétt nef, limir réttir, kátur, kringluleitur, kurteis, enginn furtur, lifir vel, nær ævi ósnauður til dauða.

Mars. $\sigma^{\star}$

[5] Marsbörn reiklynd róla, reiðigjörn frið eyða, munnvío, aflangt enni, inneygð, hefnda minnast, orku og afbragðs verkum óstöðugt pau hrósa, svefnug, svippung jafnan, sólbrennd, úti ef róla.

[6] Langharðleitur gengur,

líka eru tennur slíkar, myndað nef svo mundi,

mein er að vera einum, strákur stundar mikið stórlega illt að verka, æði andlitsrauður, aldursmikill sjaldan.

Sól. $\odot$

[7] Sólbörn sannleik mæla, svörteygð, hrein í hjarta, leyna lits ásjónu, löguð breið og fögur kinnbein, kringlótt enni, kláđugur, vitur, ráður, mislynd, máta nasir, mjúk rödd, fagur búkur.

[8] Meðalmunnur rauður, maður bjúgnefjaður, býr með burgeis herrum, brennur af ástum kvenna, út vill aldur láta, allir hálfan kalli, klug, keinesfalls verschlagen, gerade Nase, wohlgestalte Glieder, fröhlich, mit rundlichem Gesicht, höflich, kein Rüpel, lebt gut, kann ein Leben führen ohne Armut bis zum Tod.

Mars. $\delta^{\top}$

Marskinder gehen wankelmütig umher, zerstören aufbrausend Frieden, breitmundig, die Stirn länglich, hohläugig, sinnen auf Rache, Kraft und herausragende Taten loben sie unbeständig, schlafbedürftig, stets mürrisch blickend, sonnengebräunt, wenn sie im Freien umhergehen.

Geht mit langem, grimmigem Gesicht herum, auch die Zähne sind so, die Nase so geformt, daß man sich daran erinnerte, ihm ist es ein Übel, allein zu sein, der Schelm ist sehr damit beschäftigt, große Untaten zu vollbringen, überaus rot im Gesicht, selten sehr alt.

Sonne. $\odot$

Sonnenkinder sagen die Wahrheit, schwarzäugig, rein im Herzen, verbergen das Aussehen ihres Gesichts, breit geformte und schöne Wangenknochen, runde Stirn, krätzig, klug, schlau, launisch, passende Nase, sanfte Stimme, schöner Körper.

Mittelgroßer, roter Mund, ein Mensch mit gebogener Nase, lebt mit vornehmen Herren, brennt vor Frauenliebe, will das Leben verausgaben, obwohl alle es ein halbes nennen, 
fær, pó forlög rýri,

frið í dauða midjum.

Venus. 우

[9] Veneris börnin vænu vélalaus, pó spélin, snögglynd, snúðug, hyggin, snareygð, djörf í svari, sambrýnd, sío hár kemba,

senn með fallegt enni, gjöful, hýr í hófi, hrósan annars kjósa.

[10] Mjög eru föl og fögur, farfi hvítur parfur, holl og heilráđöllum, hárið ${ }^{3}$ stjórna kláru, syngja, semja strengi, glöð í dansi kveða, burðug, ber til orða, blíf hin ${ }^{4}$ óskírlífu.

Merkúríus. ఫ్

[11] Merkúrí margyrku meina ei börnin einu ört, hin andlitssvörtu, enni mjótt, klofnar tennur, löng um leggi og fingur, létt, en nasir sléttar, varastór, síð börnin bernsk í ræðu ferskri.

[12] Málarar mjög sér hæla, mikið oft prédika, akta um afbragðs spektir,

yfirlesa og skrifa, stíla á stjörnuhjóli, syndir manna grunda, dikta mælsku nægtir, menn íprótta kennast. bekommt, auch wenn das Schicksal es verringert,

Frieden mitten im Tod.

Venus. 우

Die schönen Venuskinder ohne Falsch, doch spöttisch, aufbrausend, energisch, klug, scharfäugig, kühn antwortend, mit zusammengewachsenen Brauen, kämmen langes Haar, zugleich mit schöner Stirn, freigiebig, in Maßen freundlich, wählen das Lob eines anderen.

Sind sehr blaß und schön, weiße Farbe ist dienlich, allen wohlgesonnen und guten Rat gebend, pflegen sauberes Haar, singen, stimmen Saiten, froh im Tanze reimen, tüchtig, freimütig, mögen sie die Unkeuschen bleiben.

Merkur. ఫ

Merkurs vielseitig tätige Kinder verwehren nicht schnell etwas, die Schwarzgesichtigen, schmale Stirn, gespaltene Zähne, lang an Gliedmaßen und Fingern, leicht, die Nase ebenmäßig, volle Lippen, die Kinder lange kindlich in frischer Rede.

Loben sich sehr als Maler, predigen oft viel, befassen sich mit herausragenden Weisheiten, dozieren und schreiben, formulieren auf dem Sternkreis, ergründen die Sünden der Menschen, dichten mit großer Beredsamkeit, sind als Künstler bekannt.

\footnotetext{
${ }^{3}$ Hier würde der Dativ ,hári` eher Sinn machen.

${ }^{4}$ Gibt möglicherweise eine apokopische Ausspracheform von ,blífi hin` wieder.
} 
Lúna. 『

[13] Lúnabörn með láni, litrauð, létt sér hrósa, myrkir, mikið verka, matast vel, lygð hata, siðlát, stillt, pó neita sannreynd upp á gaman, lystug líta gesti, ljóðast polinmóðir.

[14] Við tungl vaxið fæðast, víðförul, óskeggsíðu, öðrum hrá, en eyða auðug peirra brauði, stöðug lítt um leiði,
Luna. 8

Lunakinder haben Glück, rotgesichtig, loben sich leicht, verschlossen, arbeiten viel, essen gut, hassen Lüge, sittsam, ruhig, auch wenn sie eine Tatsache zum Spaß abstreiten, betrachten munter Gäste, dichten geduldig.

Bei vollem Mond Geborene, weitgereist, ohne langen Bart, harsch gegenüber anderen, verzehren aber vermögend deren Brot, wenig standhaft im Hinblick auf Fahrtwind, og á láđi og sjó peim báđum, und sowohl zu Land als auch zu Wasser, siðugur, syfjar tíðum, síd eru löt og kvíðin. wohlerzogen, oft schläfrig, spät faul und zaghaft.

Der Abnahme sind zuzurechnen die schlimmen Verächter guter Sitten, Toren und ungehobelte Burschen, die nach ihrer Auffassungsgabe zu beurteilen sind, durch die Kunst, wenn man lernt, wird manch ein Verschrobener einsichtig, grauhaarig, verständig, hütet er sich so vor Unglück.

\section{Zur metrischen Form und zur Herkunft des Inhalts}

Im folgenden soll versucht werden, einigen der Fragen, die sich im Zusammenhang mit diesem Text stellen, nachzugehen.

Zunächst zur poetischen Form: Es handelt sich um fünfzehn achtzeilige Strophen, in denen die Regeln der isländischen Stabreimdichtung der Zeit weitgehend eingehalten werden: Die Zeilenpaare sind durch Stabreime miteinander verbunden, wobei die jeweils erste Zeile zwei Stäbe aufweist und die jeweils zweite Zeile einen, der auf der ersten betonten Silbe der Zeile liegt; alle Zeilen weisen Binnenreime auf, die jeweils erste Zeile 
trägt eine halben, die jeweils zweite Zeile einen vollen Binnenreim. ${ }^{5}$ Endreime kommen nicht vor.

In den wenigen Fällen, in denen die Stabreime nicht regelmäßig gesetzt sind, könnte es sich um Störungen in der handschriftlichen Überlieferung (d.h. auf einen Abschreibevorgang zurückgehende Lese- oder Schreibfehler) handeln. Bei den Stellen, an denen statt eines zu erwartenden vollen Binnenreims ein halber Binnenreim steht, und umgekehrt, kann man davon ausgehen, daß sich der Verfasser des Gedichts diese dichterische Freiheit bewußt genommen hat. Insgesamt folgt der Text aber den damals in Island üblichen metrischen Regeln - mit Stab- und Binnenreimen, ohne Endreime; siehe z.B. die Ausführungen zur traditionellen isländischen Metrik bei Kristján Árnason (2013: passim).

Die Syntax des Gedichts läßt eine deutliche Tendenz zur Ellipse erkennen. Dies kann nicht verwundern, denn der Dichter will möglichst viele Informationen knapp zusammengefaßt in seinem Gedicht unterbringen, muß dabei aber die metrischen Regeln beachten. Da der zu übermittelnde Inhalt nicht epischer Natur ist, sondern vor allem eine Aufzählung von äußeren Merkmalen, besonderen Eigenschaften, typischen Verhaltensweisen usw. der Planetenkinder, haben die Strophen des Gedichts weithin den Charakter von Katalogstrophen.

Eine weitere interessante Frage ist die nach der Herkunft des Inhalts des Gedichts. Da dieselbe Handschrift JS 392 8vo neben verschiedenen anderen Texten auch noch einen zweiten - prosaischen - PlanetenkinderText überliefert, liegt es nahe, diese beiden Texte miteinander zu vergleichen.

Tatsächlich sind die inhaltlichen Übereinstimmungen zwischen dem Planetenkinder-Gedicht in JS 392 8vo und dem prosaischen Planetenkinder-Text in derselben Handschrift jedoch nicht sehr spezifisch, und man kann mit Sicherheit ausschließen, daß ein direktes Abhängigkeitsverhältnis zwischen den beiden Texten besteht.

\footnotetext{
${ }^{5}$ Die auffälligsten Abweichungen von diesen Regeln sind folgende: Str. 6, Z. 6 hat statt eines vollen Binnenreims den Halbreim ,-ór-“ und ,-er-“; Str. 7, Z. 2 hat statt eines vollen Binnenreims den Halbreim ,-ört- ' und ,-art-“ (was darauf hindeuten könnte, daß es sich bei dem ungewöhnlichen ,svörteygð‘ - in der Handschrift deutlich ,svørt eigd“ geschrieben möglicherweise um eine Verschreibung für ,svarteygð‘ handelt); Str. 10,Z. 1 hat statt eines halben Binnenreims den Vollreim ,-ög' und ,-ög-'; Str. 10, Z. 5+6 müßten ,syngja und ,semja‘ mit ,glöð‘ staben; Str. 11, Z. 3 hat statt eines halben Binnenreims den Vollreim ,ört‘ und ,-ört-“; Str. 11,Z. 7 wäre ein zweites auf ,b- ' stabendes Wort zu erwarten; Str. 13, Z. 2 hat statt eines vollen Binnenreims den Halbreim ,-it-" und ,-ét-“; Str. 13, Z. 6 hat statt eines vollen Binnenreims die Assonanz ,-an-` und ,-am-`.
} 
Ganz deutlich ist dagegen die Verwandtschaft zwischen dem Gedicht und einem anderen prosaischen Planetenkinder-Text, nämlich dem in der Handschrift JS 74 8vo, die aus der Zeit um 1740 stammt. Ein Vergleich zwischen dem Gedicht und diesem Prosatext ${ }^{6}$ zeigt geradezu frappierende Übereinstimmungen; nahezu alle der in dem Gedicht in JS 392 8vo aufgezählten Charakteristika der Planetenkinder haben ihre genaue inhaltliche und häufig sogar wörtliche Entsprechung in dem Text in JS 748 vo.

Dies soll am Beispiel der beiden ersten Strophen des Gedichts verdeutlicht werden, und zwar so, daß den in dem Gedicht genannten Charakteristika - in der Reihenfolge, in der sie im Strophentext vorkommen die Entsprechungen aus dem Prosatext in JS 74 8vo gegenübergestellt werden (die Lesarten aus beiden Handschriften werden in normalisierter Orthographie wiedergegeben):

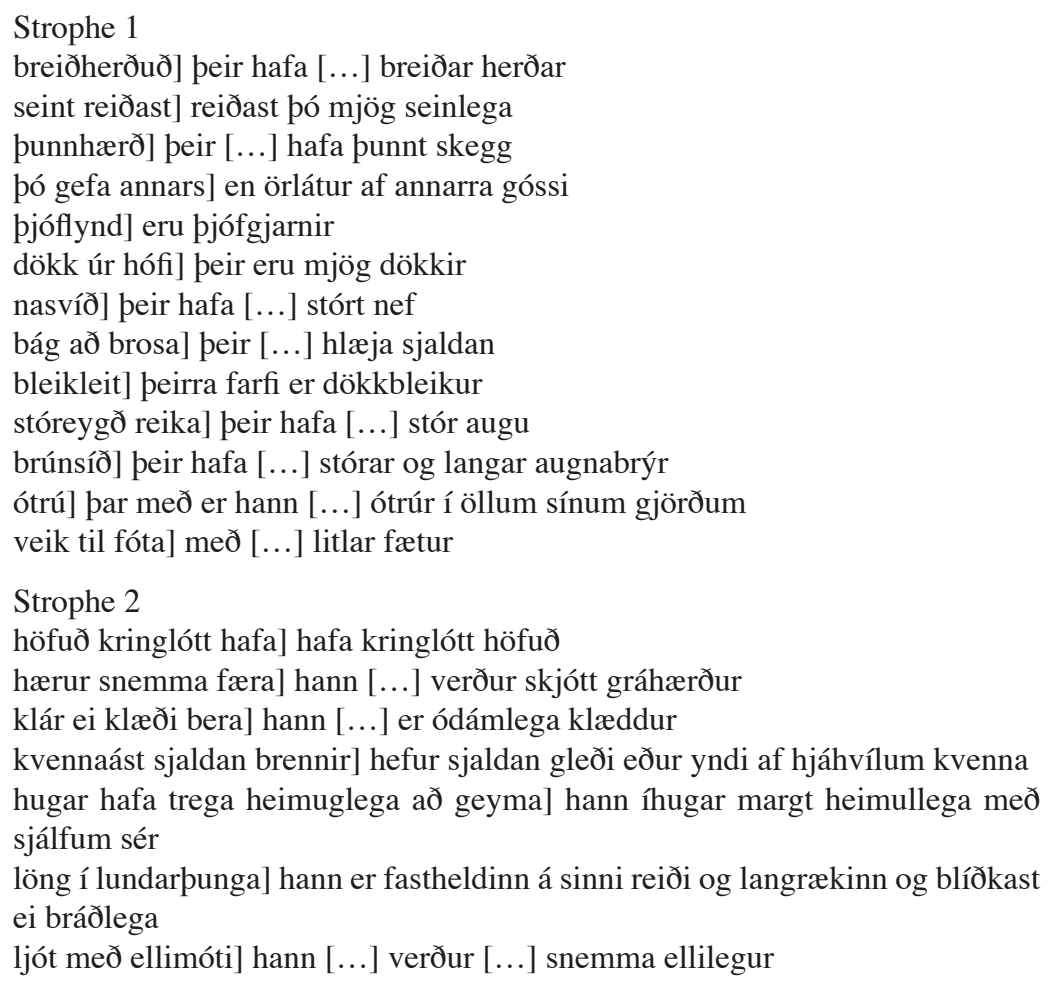

${ }^{6}$ Abgedruckt bei Bauer 2015: 178-189. 
Entsprechendes läßt sich auch für die übrigen 13 Strophen des Gedichts aufzeigen.

Es ist also davon auszugehen, daß ein prosaischer Planetenkinder-Text, der eng mit dem Text in JS 74 8vo verwandt war, dem Dichter bei der Abfassung des Gedichts als Vorlage diente.

\section{Planetenkinder-Texte im Dänischen und Deutschen}

Doch was hat es mit diesem Text in JS 748 vo auf sich? - Schon bei oberflächlicher Betrachtung fällt auf, daß der Text eine große Zahl von Danismen aufweist, was darauf hindeuten könnte, daß er nach einer dänischen Vorlage übersetzt wurde.

$\mathrm{Da} ß$ dies tatsächlich der Fall gewesen sein muß, zeigt sich, wenn man den Text in JS 74 8vo mit dem dänischen Planetenbuch vergleicht, das erstmals 1625 im Druck erschien und im 17. und 18. Jahrhundert mehrmals nachgedruckt wurde. ${ }^{7}$ - Im Isländischen Nationalmuseum in Reykjavik gibt es ein Exemplar des 1764 erschienenen dänischen Drucks. ${ }^{8}$ Das Buch hatte sich in Island befunden, war 1888 nach Schweden gelangt und wurde 2008 vom Nordischen Museum in Stockholm an Island zurückgegeben. ${ }^{9}$ Da dieser dänische Druck (von 1764) natürlich nicht als Vorlage für die isländische Übersetzung in der Handschrift JS 74 8vo (aus der Zeit um 1740) gedient haben kann, ist davon auszugehen, daß die Übersetzung nach einer der früheren Ausgaben (von 1625, 1686 oder 1710) angefertigt wurde. Doch auch der Vergleich mit dem Text des Drucks von 1764 zeigt ganz eindeutig, daß der isländische Text (wie er in JS 74 8vo überliefert

\footnotetext{
${ }^{7}$ En skiøn Planete-Bog, huor udi bescriffuis de siu Planeters met de Tolff Tegns Natur oc Complex, meget herligen affmalede, oc andre flere Stycker, som her ocsaa tilh $\phi r e$, Kopenhagen 1625. - Die dänischen Bibliographien verzeichnen weitere Drucke aus den Jahren 1686, 1710, 1764, 1784 und 1794.

${ }^{8}$ En skiøn Planete-Bog, hvor udi beskrivess de syv Planeters med de Tolv Tegns Natur oc Complex. Meget herligen afmalede, oc andre fleere Stykker, som her ogsaa tilhøre, Kopenhagen 1764.

${ }^{9}$ Die Existenz des Exemplars in Island ist ab der Zeit um 1830 belegt. Der Pfarrer Helgi Sigurðsson á Melum (1815-1888), aus dessen Besitz das Buch nach Schweden gelangte, schreibt dazu: „Pessa bók eignaðist eg, pá eg var úngur, hjá sr. Brinjólfi Bjarnasyni, í Miklaholti. Var hún pá í rotnum blöðum, en síðan hefi eg komið henni í band." Brynjólfur Bjarnason (17851850) war von 1823 bis 1845 Pfarrer in Miklaholt. Helgi Sigurðsson dürfte das zerfledderte Buch also um 1830 erhalten haben. Siehe https://sarpur.is/Adfang.aspx?AdfangID=347931.
} 
ist) nach dem dänischen Planetenbuch übersetzt wurde und sehr, sehr nahe am Text der Vorlage bleibt. Dafür einige Beispiele aus den Abschnitten über Marskinder und Sonnenkinder: ${ }^{10}$

\author{
hann er fordjarfari peirra friðsömu, \\ par til skaðlegur, reiðinn og \\ ómiskunnsamur, óstöðugur, hrósar \\ sér gjarnan af sínum verkum og \\ sefur ekki mikið, fær mikinn \\ höfuðverk]
}

Mars stendur næst plánetanum Júpíter, hann gefur sínum börnum rautt andlit, full af hita, klár og ljós augu, stundum rautt hár, með smá augu. Hans hjarta er mjög óhreint og skeytir lítið um pað góða, pað gjörir hann stundum, sem skaðlegt er, hann hefur purr kinnbein]

Sólarinnar sonur hefur eitt vænt andlit, kringlótt enni, samanbjúgar augnabrýr, svört augu, hans nef er nokkuð bjúgt í miðjunni, hann hefur kringlótt kinnbein og rauðan munn, og beygir sig nokkuð upp á sumum, hann hefur eina sæta raust, hann er kyrrlátur í öllum sínum gjörningum, hann hefur gott sinnislag, hann hefur lyst til að læra, hann er veltalandi, hann umgengst með stórherrum og styttir sér dægur með peim í allra handa málefnum]

\begin{abstract}
Han er ogsaa de Fredsommeliges Bedrøvelse, dertilmed forgiftig, vreed, ubarmhiertig, ustadig, berømmer sig gierne af sine onde Gierninger, han sover ogsaa ikke meget, dertilmed faaer han ogsaa meget Hovedverk
\end{abstract}

Mars staaer allernæst under Jupiter, han giver sine B $\varnothing r n$ røde Ansigter, fulde med Heede, klare og lyse Øyen, stundum rødt Haar, smaa Øyen, hans Hierte er meget u-reenligt, han skiøtter lidet om det som godt er, thi han giør det stundum som skadeligt er, haver tørre Kindbeen

Solens Barn haver et skiønt bredt Ansigt, en trind Pande, tilsammenbøyede Øyenbryne, sorte $\varnothing y e n$, hans Næse er midt paa lidet bøyet, og haver trinde Kindbeen, en rød Mund, som bøyer sig lidet op, en sød Røst, han er ogsaa sagtmodig udi alle sine Gierninger, haver et godt Sind, læragtig, veltalendes, og omgaaes gierne med store Herrer, og bruger Tidsfordriv med dem udi allehaande Sager

\section{Man kann also festhalten, daß der Text in JS 74 8vo auf eine Übersetzung nach dem dänischen Planetenbuch zurückgeht; er ist stark von der Sprache}

\footnotetext{
${ }^{10}$ Der isländische Text nach der Transkription in Bauer 2015: 181-183, doch in normalisierter Orthographie; der dänische Text nach der Abbildung einer Doppelseite des Drucks im Isländischen Nationalmuseum, wobei nicht eindeutig Lesbares hier durch Kursivierung gekennzeichnet ist; siehe https:/www.thjodminjasafn.is/syningar-vidburdir/adrarsyningar/gripur-manadarins/en-skion-planete-bog-stjornuspadomsbok-fra-1764.
} 
der dänischen Vorlage geprägt und folgt dem dänischen Text Wort für Wort. Wenn man aber aussagekräftig über Aufbau und Inhalt dieses isländischen Textes urteilen will, sieht man sich mit der Frage konfrontiert, wie es dazu kommt, daß der dänische gedruckte Planetenbuch-Text so aussieht, wie er ist, und nicht anders. Das heißt, man müßte sich mit den möglichen Vorlagen des dänischen gedruckten Textes beschäftigen - was den Rahmen der vorliegenden kleinen Studie sprengen würde.

Deshalb sei hierzu nur angemerkt, daß Viktor Stegemann bereits vor fünfundsiebzig Jahren eine sehr informative Arbeit über die „Entstehung, Herkunft und Nachwirkung“ des deutschen Planetenkinder-Textes veröffentlicht hat (Stegemann 1944). In ihr erfährt man u.a., daß der aus dem Lateinischen übersetzte, in Handschriften überlieferte deutsche Text in eines der volkstümlichen Planetenbücher aufgenommen wurde, das erstmals 1544 in Straßburg im Druck erschien, bis zur Jahrhundertwende 1600 zahlreiche weitere Auflagen erlebte und im 17. Jahrhundert und bis über die Mitte des 18. Jahrhunderts immer wieder praktisch unverändert nachgedruckt wurde. - Eine Zusammenfassung der Untersuchungsergebnisse Stegemanns findet sich bei Angelika Merk (2018: $89 \mathrm{ff}$ ).

Der Anfang des von Stegemann abgedruckten deutschen Planetenkinder-Textes in einer kurz nach 1400 in Ulm entstandenen Handschrift (Universitätsbibliothek Augsburg, Öttingen-Wallerstein Cod. III. 1. $4^{\circ} 1$ ) lautet (siehe Schneider 1988: 240-248): „[A]ber von natur und aygenschaft der siben planeten wil ich kưrczlich etwaz schriben." Dieser Wortlaut schimmert deutlich erkennbar noch in der Überschrift des isländischen Planetenkinder-Textes in JS 74 8vo durch (Bauer 2015: 178 - hier in normalisierter Orthographie): „Nú eptirfylgir hér næst náttúra og eigindómur peirra sjö plánetna, sem pessi bæklingur hefur inni að halda.“

In der Ulmer Handschrift werden die Planetenkinder in der Reihenfolge Saturn - Jupiter - Mars - Sonne - Venus - Merkur - Mond behandelt, d.h. in derselben Abfolge wie auch im Prosatext in JS 74 8vo und im Gedicht in JS 392 8vo.

Ein Vergleich mit dem 1559 in Straßburg erschienenen Planetenbuch (Brenner 1559) zeigt, daß die Planetenkinder dort in der Reihenfolge Sonne - Venus - Merkur - Mond - Saturn - Jupiter - Mars behandelt werden, wie dies auch im isländischen Planetenkinder-Text in der Handschrift Lbs 1709 8to der Fall ist. ${ }^{11}$ Hieraus darf man schließen, daß zumindest zwei unterschiedliche Traditionen des Planetenkinder-Textes nach Island gelangt sind.

\footnotetext{
${ }^{11}$ Siehe Bauer 2015: 158-159.
} 


\section{Exkurs: Kritische Anmerkungen zur Laienastrologie und Laienphilologie}

Die überaus reiche isländische Handschriftenüberlieferung aus der Zeit nach der Reformation ist noch immer nicht umfassend erforscht. Noch immer lassen sich in den Sammlungen isländischer Manuskripte höchst interessante Dinge finden - Texte und Textsorten, deren Existenz zwar in den einschlägigen Handschriftenkatalogen vermerkt ist, über die man aber sonst so gut wie nichts weiß.

In ihrer 2015 publizierten Habilitationsschrift Laienastrologie im nachreformatorischen Island. Studien zu Gelehrsamkeit und Aberglauben behandelt Alessia Bauer eine Gruppe solcher, bislang von der Forschung weitgehend vernachlässigter Texte (Bauer 2015), darunter auch das Planetenkinder-Gedicht in der Handschrift JS 392 8vo. Über diesen Text heißt es dort (Bauer 2015: 202):

Auf den Seiten 22-25 [=B1. 13v-15r der Handschrift JS 392 8vo] ist eine erste Schrift - viel kürzer als die soeben vorgestellte [d.h. der Prosatext über die sieben Planeten auf B1. 17v-24v derselben Handschrift] - über die sieben Planeten belegt, die, wie der Titel „Siø Planetur i Liődmælumm“ ankündigt, in gebundener Sprache verfasst ist. Doch ist im Text kein richtiges Reimschema auszumachen, lediglich alliterierende Langzeilen sowie eine von Prosa abweichende Syntax, in der das Personalpronomen meist fehlt und das Verb gelegentlich auch ausgelassen oder ans Satzende gestellt wird.

Die Darstellung der Planetenmenschen ist viel knapper gehalten als im zweiten Text und die Beschreibung der anatomischen und charakterologischen Merkmale deckt sich nur partiell. In Anbetracht des umfassenderen Textes ab S. $30[=$ B1. 17v] stellt sich dem heutigen Leser die Frage nach dem Sinn dieser Wiederholung - eine Überlegung, die offenbar den Schreiber in seinem enzyklopädischen Bestreben nicht berührte.

Im Anschluß hieran, auf S. 202-203 der Habilitationsschrift, folgt dann der Gedichttext, wobei dieser innerhalb der sieben Planeten-Abschnitte fortlaufend - nicht in Strophenform - abgedruckt ist.

Wie die Verfasserin mehrfach ausdrücklich feststellt, strebt sie bei der Transkription größtmögliche Texttreue an (Bauer 2015: 144-146, 157):

Die Textwiedergabe ist durchgängig diplomatarisch, d.h. die Texte werden in einer buchstabengetreuen Transkription wiedergegeben [...] 
Die z.T. zahlreichen Abbreviaturen wurden aufgelöst und durch Kursiva kenntlich gemacht. [...]

Die Orthographie wird nicht normalisiert [...]

Klein- und Großschreibung, obwohl sie nicht immer eine satzgliedernde Funktion erfüllen, wurden übernommen. [...]

Die Interpunktion, die keine Systematisierung aufweist, wurde nicht normalisiert und so übernommen, wie die Handschriften sie präsentieren. [...]

Die Texte werden wortgetreu wiedergegeben und ohne die Orthographie zu verändern $[\ldots]$

Ein Vergleich zwischen abgedrucktem Gedichttext und Handschriftentext zeigt jedoch, daß mit diesen selbstgesetzten Regeln recht nonchalant umgegangen wird: auf den anderthalb Druckseiten, die das Gedicht einnimmt (S. 202-203) finden sich zwischen fünfzig und sechzig Stellen, an denen diese Regeln deutlich nicht befolgt werden. In etwa einem Drittel der Fälle handelt es sich um die ungenaue Wiedergabe der Interpunktion der Handschrift, Kommata und Punkte werden bei der Transkription übersehen oder dort gesetzt, wo im Manuskript keine Interpunktionszeichen stehen. Andere Abweichungen betreffen die Kursivierung aufgelöster Abbreviaturen (z.B. Z. 4 ,annars' statt korrekt ,annars $\left.{ }^{6}\right)^{12}$ und das Unterschlagen oder nicht korrekte Identifizieren diakritischer bzw. interlinearer Zeichen (z.B. Z. 21 ,Rola' statt ,Röla', Z. 39 ,børne“ statt ,børnen‘, Z. 42 ,hỏfe‘ statt ,hófe‘ oder Z. 62/63 ,ä lan/de‘ statt ,ä lä/ $\left.\mathrm{de}^{6}\right)$. Der überaus deutliche Großbuchstabe am Anfang der zweiten Jupiter-Strophe wird klein wiedergegeben (Z. 15 , fryd $u r^{6}$ statt ,Frydur ${ }^{6}$ ), Buchstaben werden nicht oder falsch gelesen (z.B. Z. 53 ,afbrads' statt ,afbragds “, Z. 66 ,lagst' statt ,lagast', Z. 5 ,døckur' statt ,døch ur', Z. 39 ,Venerij' statt ,Veneriz', Z. 50 ,oliettar ${ }^{`}$ statt ,sliettar ${ }^{\star}$, Z. 53 , speyter statt , spegter ${ }^{6}$, Z. 60 ,biödast' statt ,liödast', Z. 65 , gicke' statt ,giche“, Z. 66/67, hæ/edur' statt ,hæ/rdur'). Schließlich werden in einer ganzen Reihe von Fällen Abbreviaturen ohne Rücksicht auf die Orthographie der Handschrift oder den Sinnzusammenhang aufgelöst (z.B. Z. 9 ,hemuglega' statt ,heimuglega', Z. 15 ,verda' statt ,virda', Z. 22 ,minnst statt ,minnast ${ }^{6}, \mathrm{Z} .25$, gengur' statt , geingur', Z. 44 , syngja und ,semja statt, syngia' und ,semia, Z. 66 ,firir' statt ,firer ${ }^{6}$ ).

${ }^{12}$ Zeilennumerierung wie in meiner zeilengetreuen Transkription des Gedichts nach der Handschrift, siehe oben. 
Die bei der Transkription gemachten Fehler lassen vermuten, daß diesem Gedicht nicht besonders viel Aufmerksamkeit zuteil wurde und man sich offensichtlich nicht die Mühe gemacht hat, den Text wirklich Wort für Wort zu verstehen - sonst wären so sinnentstellende Fehllesungen wie ,oliett $a r^{\text {‘ }}$ statt ,sliettar ${ }^{\star}$ oder ,biödast` statt ,liödast` korrigiert worden. Der Umstand, daß sich unter den im Anhang der Arbeit abgedruckten deutschen Übersetzungen der behandelten Texte keine Übersetzung des Gedichts befindet, scheint diese Vermutung zu betätigen. ${ }^{13}$

Das Planetenkinder-Gedicht wird in der Habilitationsschrift also eher stiefmütterlich behandelt, wobei das wenige, das dort über das Gedicht zu finden ist, einer genaueren Überprüfung nicht standhält. Dies läßt Zweifel an der wissenschaftlichen Qualität der Arbeit aufkommen. Und je länger man man sich mit ihr beschäftigt, desto mehr werden diese Zweifel zu der Gewißheit, daß sich hier erstaunliche Defizite manifestieren.

Am auffälligsten ist der Mangel an philologischer Genauigkeit und sprachhistorischer Expertise, der sich in den Transkriptionen der isländischen Handschriftentexte offenbart. Zwar werden sehr vernünftige Regeln aufgestellt, nach denen beim Transkribieren verfahren werden soll, doch dann wird ständig gegen diese selbst aufgestellten Regeln verstoßen. Eine Durchsicht der Texte, bei denen sich die Zuverlässigkeit der Transkription ohne größeren Aufwand nachprüfen läßt (weil Bilder der betreffenden Handschriften im Internet abrufbar sind), zeigt, daß das oben angeführte Beispiel der Transkription des Planetenkinder-Gedichts in JS 392 8vo beileibe keinen Einzelfall darstellt, sondern symptomatisch ist: die Fehlerhäufigkeit ist durchwegs sehr groß, völlig korrekt transkribierte Zeilen sind die Ausnahme, häufig finden sich in jeder gedruckten Zeile zwei oder drei Fehler.

${ }^{13}$ „Anhang 2: Übersetzung der Texte“,S.470-626. Dort heißt es einleitend u.a.(S. 471): „Die Texte werden in derselben Reihenfolge präsentiert, wie sie in der Abhandlung vorkommen, beginnend mit den Planetenbüchern." - Auf die Übersetzung des in der Handschrift JS 392 8vo überlieferten (auf S. 193-201 der Abhandlung abgedruckten) Planetentextes in Prosa (Anhang, S. 497-505) folgt unmittelbar die Übersetzung des in der Handschrift Lbs 767 4to überlieferten (auf S. 205-206 der Abhandlung abgedruckten) Planetentextes in Prosa; dazwischen (d.h. nach S. 505 und vor S. 506 des Anhangs) hätte die Übersetzung des in JS 392 8vo überlieferten Gedichts ihren Platz. - Die Aussage, „die Texte werden in derselben Reihenfolge präsentiert, wie sie in der Abhandlung vorkommen," ist nicht nur hier cum grano salis zu nehmen: im Unterkapitel 5.6 Monatsregeln und Monatsnamen (S. 296-351) ist die Abfolge der behandelten Handschriften Lbs 808 8vo - JS 393 8vo - ÍBR 43 8vo - Lbs 1709 8vo; bei den Übersetzungen der Texte im Anhang (S. 573-617, „Texte über die Monatsnamen und -regeln“) dagegen Lbs 1709 8vo - Lbs 808 8vo - ÍBR 43 8vo - JS 393 8vo. 
Ein bezeichnendes Beispiel dafür, wie nachlässig mit den Texten umgegangen wird, ist das Titelblatt des Tierkreiszeichentraktats auf Bl. 161r der Handschrift JS 392 8vo, dessen Text an zwei Stellen in der Arbeit abgedruckt ist. Auf S. 191-192 der Habilitationsschrift, im Kapitel 5.4 Planetenkinder-Traktate, lautet die Transkription dieses Textes so:

Bæklingur Lytill umm Gaang og Edlis hatt peirra Toolf Merkia i Zodiaco og peirra siø Planeta Er Lausar Rerka under Zodiaco, A Imsumm Astronomiskum $m$ Bokum $m$ wtlagdur og skrivadur. Græco Latinsk Ord Nockur a Islendsku wtløgd og pau hier fyste sett um himenen $n$ og himensins her skara og pau eru Grundvøllur pessa Bæklings. Nu ad nyu skrifad Anno 1757 af fá vitrum Porkele Jonssyne á Hraune i Grindavyk.

Auf S. 366, im Kapitel 5.8 Texte zu den vier Elementen, lautet er dagegen so (die Abweichungen gegenüber der ersten Fassung hier durch Fettdruck und Unterstreichung gekennzeichnet):

Bæklingur Lytill umm Gang og Edlis hatt peirra Toolf Merkia I Zodiaco

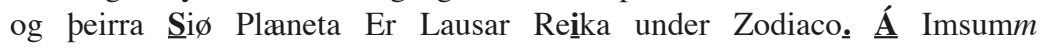

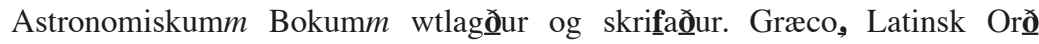

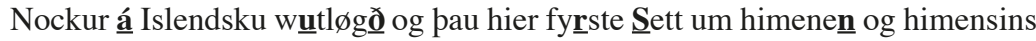
her skara og pau eru Grundvøllur pessa Bæklings. Nu a a nyu skrifaoِ Anno $175 \underline{\mathbf{2}}$ af fá vitrum $m$ Porkele Jonssyne $\underline{\underline{A}}$ Hrane í Grindavyk.

Die beiden Transkriptionen, die eigentlich denselben Handschriftentext wiedergeben sollen, unterscheiden sich also an zweiundzwanzig Stellen voneinander. - Korrekt nach der Handschrift transkribiert müßte der Text so aussehen (die Abweichungen - der beiden Fassungen untereinander und der Fassungen gegenüber dem Text der Handschrift - sind fett gedruckt und unterstrichen):

Bæklingur Lütill, um $m$ Gaang og Edlis hatt peirra Toolf Merkia I Zodiaco, og peirra si $\varnothing$ Planeta, Er Lausar Reikka vnder Zodiaco. Af Jmsumm Astronomiskum $m$ Bookum $m$ wtlagdur og skrif̣adur. Græco_ Lạ́tinsk, Ord Nockur a J Jlendsku w w her skara og pau eru Grundvøllur pessa Bæklings_ Nu Ad næ̈u skrifad Anno $175 \underline{\underline{2}}$ af fậ vitrum $m$ Porkele Jonssyne ẩ Hraune i Grindavyk.

An siebenunddreißig Stellen ist also der Text der Handschrift von mindestens einer der beiden abgedruckten Transkriptionen nicht korrekt wiedergegeben..$^{14}$

\footnotetext{
${ }^{14}$ Statistisch ausgewertet sähe dieser Befund so aus: Der Text besteht aus 341 Zeichen
} 
Die Unzulänglichkeit der Transkriptionen dürfte auch darauf zurückzuführen sein, daß es der Verfasserin offensichtlich an den für eine solche Untersuchung nötigen Sprachkenntnissen mangelt. Dies wird im Anhang der Arbeit deutlich, wo die transkribierten Texte ins Deutsche übersetzt abgedruckt sind (S. 470-626). In der Vorbemerkung zu diesem Anhang heißt es u.a. (S. 470-471):

Die Übersetzung der in der Studie vorgestellten Texte versteht sich als Hilfestellung für Fachleute anderer Disziplinen, die der isländischen Sprache nicht mächtig sind. Zugleich soll auch dem Altnordisten dort weitergeholfen werden, wo sich das postreformatorische Isländische von der älteren Sprachstufe durch einen massiven Einfluss des Dänischen und Niederdeutschen änderte und seinen Wortschatz um zahlreiche Wörter vermehrte. Auffallend in den präsentierten Schriften sind nicht nur Entlehnungen aus den genannten Sprachen, sondern auch eine sonderbare Bildungsweise auf der Basis fremder Suffixe, aus denen eigentümliche Neologismen entstanden. [...]

Eine Übersetzung kann lediglich eine vage Idee dieser Texte vermitteln; sie versucht, dem isländischen Text inhaltlich so eng wie möglich zu folgen, und verzichtet auf verschönernde Ausformulierungen, die im Original so nicht intendiert sind. [...]

Die Texte operieren oft assoziativ oder aber kontrastiv, sodass keine besondere Logik zu erkennen ist, die eine bestimmte Deutung suggerieren könnte. [...]

Obwohl die Interpunktion im Original keine Systematik aufweist und beinah zufällig verwendet wird, wird in der Übersetzung eine konsequentere Aufteilung der Sätze vorgenommen und unterschiedliche Interpunktionszeichen angewandt, die eine längere oder kürzere Zäsur zwischen den Sätzen markieren sollen.

Diese Aussagen haben etwas unfreiwillig Parodistisches an sich, und der Satz „Eine Übersetzung kann lediglich eine vage Idee dieser Texte vermitteln“ müßte eigentlich lauten „Diese Übersetzung kann lediglich eine vage Idee dieser Texte vermitteln“, denn die Zahl der schiefen oder falschen Übersetzungen, der Ungereimtheiten und der Mißverständnisse in den übersetzten Texten ist Legion. Hier nur einige wenige Beispiele (zuerst der Originaltext in normalisierter Orthographie, nach der eckigen Klammer die Übersetzung, jeweils mit Seiten- und Zeilenangabe):

(ohne Leerzeichen), davon sind 38, d.h. über 11\%, nicht korrekt wiedergegeben. - Der Text besteht aus 67 Wörtern; 8 der 38 nicht korrekt wiedergegebenen Stellen betreffen Interpunktionszeichen, bleiben also 30 Wörter; in fünf dieser 30 Wörter sind je zwei Abweichungen vom korrekten Text festzustellen, bleiben also de facto 25 Wörter, d.h. über $37 \%$ aller Wörter sind in mindestens einer der beiden Fassungen nicht korrekt transkribiert. 
S. 160, Z. 8: sem höggormur] S. 472, Z. 11: wie ein Skorpion (statt wie eine Schlange)

S. 161,Z. 18-19: koma vel fyrir sínum orðum í dómum og réttargangi] S. 473, Z. 28-29: halten ihr Wort in Urteil und Gerechtigkeit (statt verstehen es, ihre Worte zu wählen vor Gericht und bei Prozessen)

S. 163, Z. 7-10: peirra hjarta og sinni er ekki eins og pau tala með tungunni, heldur talar tungan pað eina en meinar annað í hjartanu] S. 475, Z. 23-26: ihr Herz und Geist sind nicht im Einklang und sie sprechen mit der Zunge, vielmehr spricht die Zunge das, was sie im Herzen nicht meinen (statt ihr Herz und Sinn ist nicht so, wie sie mit der Zunge sprechen, sondern die Zunge spricht das eine, meint aber etwas anderes im Herzen)

S. 187, Z. 22-23: hans sinni stendur eftir tímanlegum hlutum] S. 495, Z. 22: sein Gemüt richtet sich aktuellen Dingen zu (statt sein Sinn steht nach irdischen Dingen)

S. 187, Z. 33-34: Hann er góðgjörðasamur] S. 495, Z. 32: Er ist ein vollkommener Mensch (statt Er ist wohltätig)

S. 201, Z. 10-11: stundar uppá stundlega hluti og pað, sem er forfengilegt] S. 505, Z. 10-11: lernt vorübergehende Dinge und das, was verfänglich ist (statt er trachtet nach weltlichen Dingen und dem, was eitel ist)

S. 321, Z. 27: í peirri merkilegu bók] S. 605, Z. 1-2: in dem sonderbaren Buch (statt in dem bemerkenswerten Buch)

S. 322, Z. 33: uppástendur H. P. Claussen] S. 606, Z. 6: beanstandet H. P. Claussen (statt behauptet H. P. Claussen)

Besonders deutlich treten die Defizite an philologischer Kompetenz auch dort zutage, wo die Tatsache, daß eine Textstelle nicht verstanden wird, durch eine weitschweifige Fußnote kaschiert werden soll. Hierfür zwei Beispiele:

In dem Abschnitt über die Planetenkinder der Venus heißt es in der Handschrift JS 74 8vo (S. 185, Z. 26 - hier in normalisierter Orthographie): „Par fyrir er hann einn bólari.“

Dies ist so übersetzt (S. 493, Z. 29-30): „Aufgrund dessen ist er eine kokette Person(?).“ Dazu gibt es folgende Anmerkung (Fußnote 458):

In Original steht bolare, ein Wort, das in der isländischen Sprache nicht anderweitig belegt ist. Es könnte mit [ergänze dem] dän. Verb bole zusammenhängen, das u. a. die Bedeutung ,,anvende (noget) som middel til at behage; kokettere med“" aufweist. Vom Verb abgeleitet wird das Substantiv boleri gebildet. Siehe dazu Ordbog over det danske sprog [sic] Bd. 2 1920, Sp. $958 f$. 
Das im Isländischen sonst nicht belegte Wort bólari geht mit an Sicherheit grenzender Wahrscheinlichkeit auf das Dänische boler, im Älteren Neudänisch bolere, zurück, das, nebenbei gesagt, ebenfalls in Ordbog over det danske Sprog aufgeführt ist; es entspricht dem deutschen Buhler. Die deutsche Übersetzung des Satzes müßte also lauten: „Deshalb ist er ein Buhler.“ - In dem oben bereits erwähnten Straßburger Druck von 1559 des deutschen Planetenbuchs (Brenner 1559) heißt es an dieser Stelle: „darum ist er ein bůlhertz“.

In dem anderen Fall handelt es sich um eine Stelle im Text über den Monat August in der Handschrift ÍBR 43 8vo (B1. 154v), die in der Transkription so lautet (S. 326, Z. 25-27 - hier in normalisierter Orthographie): „Pessari gyðju hafa peir kirkjur gjört og offrað henni aðskiljanleg[a] ávexti og jarðargróða, líka einu svíni [...]“. Eine Anmerkung (Fußnote 382) zu ,aðskiljanleg[a]' erläutert, weshalb hier eine Änderung im Text vorgenommen wurde:

Im Original steht fälschlicherweise eine Abkürzung für -an (als Endung des mask. Sg. Akk.). Da aber ávexti Plural ist, muss der Text durch die Endung - $a$ emendiert werden.

In der Handschrift steht jedoch nicht, adskilianlegan', wie hier behauptet wird, sondern , adskilianleg $\mathrm{um}^{6}$, geschrieben mit einem interlinearen , $\mathrm{m}^{6}$, wie es der Schreiber der Handschrift sehr häufig verwendet; das Wort ,ávexti‘ ist hier kein Akkusativ Plural, sondern ein Dativ Singular. Nach dem Verb offra steht hier sowohl derjenige, dem man opfert (,henni'), als auch das, was man opfert (,ávexti“, ,jarðargróða“, ,svíni‘), im Dativ. Das vorausgestellte ,aðskiljanlegum' paßt inhaltlich und formal zu den beiden folgenden Substantiven (,ávexti ${ }^{\circ}$, ,jarðargróða'), und es besteht kein Anlaß zu einer Emendierung. Die Textstelle lautet also: „Pessari gyðju hafa peir kirkjur gjört og offrað henni aðskiljanlegum ávexti og jarðargróða, líka einu svíni [...]“" (,Dieser Göttin haben sie Kirchen errichtet und ihr allerlei Obst und Feldfrucht geopfert, auch ein Schwein $\left.[\ldots]^{\circ}\right)$.

Man kann sich der Erkenntnis nicht verschließen, daß in der vorliegenden Habilitationsschrift das Mindestmaß dessen, was man an philologischer Genauigkeit von einer ernstzunehmenden wissenschaftlichen Untersuchung erwarten darf, weit unterschritten wird. Mit einer derart fehlerhaften, unzuverlässigen Edition und Übersetzung von Texten ist niemandem gedient.

Doch wie steht es mit den anderen, nicht primär textphilologischen 
Teilen der Arbeit? Auch hier sind bei genauerer Lektüre ganz eklatante Defizite nicht zu übersehen.

Die ersten Kapitel der Arbeit (bis S. 141) führen in das Thema ein und skizzieren Hintergrund und Umfeld der Untersuchung. - Kapitel 1 (S. 9-42) gibt einen knappen Abriß der politischen Geschichte, Geistesgeschichte und Sprachgeschichte Islands in der Frühneuzeit und ergänzt Handbuchwissen mit Fußnoten und gelehrten Exkursen, deren Relevanz sich dem Leser nicht immer erschließt. Schon hier wird der fatale Mangel an Isländischkenntnissen bzw. die Nachlässigkeit im Umgang mit dem Isländischen evident - viele der verwendeten isländischen Namen und anderen Wörter sind falsch geschrieben. ${ }^{15}$ - Kapitel 2 (S. 43-62) gibt einen informativen Überblick über die Disziplinen Astronomie und Astrologie von der Antike bis ins 18. Jahrhundert, basierend auf den Arbeiten von Zinner und anderen Standardwerken. Warum gegen Ende dieses Kapitels, wo es um die weitgehende Akzeptanz des kopernikanischen Weltbilds in Deutschland, England und Skandinavien geht, in einer Fußnote (S. 61) auf Kapitel 5.8 verwiesen wird, bleibt rätselhaft, denn Kapitel 5.8 (S. 364-369) behandelt „Texte zu den vier Elementen“. - Kapitel 3 (S. 6389) definiert den Begriff ,Laienastrologie‘ und skizziert die Geschichte der laienastrologischen Literatur; außerdem wird auf Spuren dieser Traditionen in der altnordischen Literatur (Snorra Edda, Elucidarius, Hauksbók, Barlaams saga, Rímbegla, Alfraði íslenzk) hingewiesen. - Ein Kapitel 4 sucht man vergebens.

Kapitel 5 (S. 90-401), die eigentliche Untersuchung, gliedert sich in zehn Unterkapitel, deren erstes (5. Das isländische Fachschrifttum, S. 90118) nochmals eine Art Einleitung darstellt, in der die Grundannahmen, auf der die Untersuchung basieren soll, skizziert werden. Der rhapsodische Aufbau dieses Unterkapitels macht es dem Leser schwer, den diesbezüglichen Gedankengängen zu folgen: es wird eine Vielzahl von Schlüsselbegriffen aus unterschiedlichen, mehr oder weniger aktuellen Richtungen und Methoden der Literatur- und Kulturwissenschaft bemüht, ohne daß ersichtlich wäre, welche Relevanz ihnen tatsächlich für die Arbeit an und mit den Texten zukommen kann bzw. soll. Deutlich wird hingegen das Bestreben, Phänomene, die für die Überlieferung von

${ }^{15}$ So zum Beispiel: ,skattegjald“ statt ,skattgjald‘ (S. 16); ,Estribygð‘ statt ,Eystribygð‘ (S. 17); ,Einnarsson“ statt ,Einarsson', ,Sótt og dauða íslenskunnar' statt ,Sótt og dauði íslenskunnar', ,Skáltholt‘ statt ,Skálholt‘ (S. 19); ,stjórnamálefni` statt ,stjórnarmálefni‘ (S. 20); , Guðbrandsbíblia‘ statt ,Guðbrandsbiblía‘ (S. 26); ,Mannsöngvar‘ statt ,Mansöngvar (S. 32); ,Jón Eggertsson aus Ökrum‘ statt ,Jón Eggertsson aus Akrar` (S. 37). 
Texten in vorliterarischen Gesellschaften typisch sind, auf das 17. bis 19. Jahrhundert in Island zu übertragen, wobei immer wieder die eigenartig romantische Vorstellung zum Ausdruck kommt, daß selbst noch in dieser Zeit die Mündlichkeit bei der Überlieferung von Sachprosa eine wichtige Rolle gespielt habe. Die Tatsache (oder vor der Untersuchung: die begründete Annahme), daß die im nachreformatorischen Island $\mathrm{zu}$ Papier gebrachten laienastrologischen Texte letztlich auf gedruckte dänische oder deutsche Ausgaben zurückgehen, wird bei diesen Überlegungen dagegen nur sehr dürftig berücksichtigt (S. 114):

Über die Quellen der untersuchten Texte ist Folgendes anzumerken: Im isländischen Fachschrifttum werden sie kaum preisgegeben, doch verraten der Wortschatz und gelegentliche Eintragungen, wie beispielsweise in ÍB 643 8vo Nockuð uтm Grøs úr pýsku Herbario (,Etwas über Kräuter aus einem deutschen Herbarium'), dass den Isländern nicht nur dänische Vorlagen, sondern auch deutsche zu $[s i c]$ Verfügung standen.

Stattdessen wird - ohne zu berïcksichtigen, daß diese Texte nicht in Island verfaßt, sondern Wort für Wort aus dem Dänischen oder Deutschen übersetzt wurden - ausführlich über ihre besondere inhaltliche und syntaktische Struktur, die spezielle Funktion von Parallelismen in der Sachprosa, den Wahrheitsgehalt von Haupt- und Nebensätzen und die Frage nach der Deckungsgleichheit von Sinn und Vorstellung eines Zeichens räsoniert.

Das kurze Unterkapitel 5.1 (S. 118-127) führt diese Überlegungen fort und skizziert die Entwicklung des physikalischen Weltbildes der Nordgermanen ,,von einem Stadium des mythischen Denkens zur theoretischen Erkenntnis [...] auf einer pseudo-wissenschaftlichen Ebene“ (S. 118), wobei für die Zeit des nordischen Mittelalters vor allem Völuspá, Grímnismál, Snorra Edda und Konungsskuggsjá als Quellen angeführt werden. - Mit dem Unterkapitel 5.2 (S. 127-141), das den Besonderheiten des Wortschatzes gewidmet ist, begibt man sich dann wieder auf sehr glattes Eis. Die Darstellung der Entwicklung des Isländischen und insbesondere der Geschichte des isländischen Sprachpurismus stützt sich auf eine schwer nachvollziehbare Auswahl von Werken der Sekundärliteratur und ist nicht eben erhellend. Deutlich macht sich dagegen wieder der Mangel an Sprachkompetenz und philologischer Exaktheit bemerkbar. ${ }^{16}$

\footnotetext{
${ }^{16}$ So wird u.a. behauptet, isländisch ,ektaskap‘ gehe auf dänisch ,ægtepar‘ zurück, und
} isländisch ,dægilegur‘ auf dänisch ,daglig‘ (S. 136); der Dichter Jónas Hallgrímsson, der 
Die Kapitel 5.3 bis 5.8 (S. 141-369) enthalten die Transkriptionen der laienastrologischen Texte, nach ihrem Inhalt zu Gruppen zusammengefaßt. Das Kapitel 5.9 (S. 369-388) stellt die wissenschaftlichen astronomischen Texte, die in der Handschriftenabteilung der isländischen Nationalbibliothek aufbewahrt werden, vor. Ihm schließen sich drei kurze Unterkapitel 5.9.1 bis 5.9.3 (S. 388-401) über „Das isländische Schulwesen“, „Das Weltbild gelehrter Isländer“ und „Björn Gunnlaugsson: Mathematiker, Astronom und Oberlehrer" an. - Auf die deutsche Zusammenfassung, Kap. 6 (S. 402-412), und ein englisches Summary, Kap. 7 (S. 413-425), folgen das Literaturverzeichnis (S. 426-444) und eine Liste der Handschriftensiglen (S. 445-446).

Der Anhang 1 (S. 447-469) trägt die Überschrift „Ausführliches Verzeichnis der untersuchten Handschriften“, die Eintragungen sind jedoch sehr knapp gehalten. - Der Anhang 2 (S. 470-626) enthält die deutschen Übersetzungen der in Kapitel 5.3 bis 5.8 transkribierten Texte. Farbige Abbildungen von je einer Seite aus vier verschiedenen Handschriften bilden den Abschluß der Arbeit (sind aber im Inhaltsverzeichnis nicht aufgeführt).

Die deutsche Zusammenfassung der Habilitationsschrift beginnt mit dem Satz (S. 402): „Die Untersuchung hatte sich zum Ziel gesetzt, eine bestimmte Sparte der isländischen Fachliteratur zugänglich zu machen, die bisher von der skandinavistischen Forschung - im Übrigen auch auf Island - kaum Beachtung gefunden hat.“ Darüber, daß die Untersuchung dieses selbstgesteckte Ziel gründlich verfehlt, kann jedoch kein Zweifel bestehen. Aufgrund der unübersehbaren, sehr gravierenden Mängel, was Sprachkompetenz, philologische Genauigkeit, paläographisches und kodikologisches Wissen sowie Vertrautheit mit den isländischen Verhältnissen (Sprach-, Literatur- und Kulturgeschichte) betrifft, sind die abgedruckten Transkriptionen (einschließlich der deutschen Übersetzungen) unzuverlässig und schlichtweg nicht zu gebrauchen. Die Texte sind also nur scheinbar zugänglich gemacht worden.

Hier wäre daran zu erinnern, daß Stefán Karlsson bereits vor Jahrzehnten eindringlich vor Textausgaben gewarnt hat, „der er udført af mindre kvalificerede udgivere. Disse udgivere kan jo være nok så energiske og omhyggelige, men hvis de ikke kan deres oldislandske grammatik og ikke - i tilfælde af at de skal arbejde med yngre håndskrifter - har et kendskab til grundtrækkene i senere islandsk sproghistorie, så kommer de uvægerlig til kort over for deres opgave.“ (Stefán Karlsson 2016: 317).

u.a. Ursin ins Isländische übersetzte, wird ,Jónas Hallgrímur‘ genannt (S. 138); Bjarni Vilhjálmsson heißt zweimal ,Bjarni Vilhjámsson‘ (S. 139). 
Was die Verdienste der Arbeit im Hinblick auf die Konstituierung eines Corpus der isländischen laienastrologischen Literatur in nachreformatorischer Zeit anlangt, so sind auch diese eher bescheiden. Die Untersuchung beschränkt sich auf die Sichtung der einschlägigen Manuskripte in der Isländischen Nationalbibliothek; Handschriften in anderen Sammlungen isländischer Handschriften, etwa in Dänemark, Schweden oder Großbritannien, werden nicht berücksichtigt. ${ }^{17}$ In der Einleitung wird festgestellt (S. 7): „Grundlage der Untersuchung stellen etwa 200 Handschriften dar, die im Landsbókasafn Íslands in Reykjavík aufbewahrt werden.“ Späterhin heißt es (S. 142): „Das Textcorpus setzt sich aus über 200 Handschriften zusammen [...]". Welche Manuskripte dies sind, wird nicht gesagt. In dem „Verzeichnis der Handschriften“ (S. 445-446) sind, neben 22 Manuskripten, die „Wissenschaftliches Schrifttum“ bzw. Rímbegla enthalten, 94 Handschriften mit laienastrologischen Texten aufgelistet. Dieselben 116 Handschriften - wenn auch in anderer Reihenfolge ${ }^{18}$ - werden im Anhang 1 (S. 447-469) kurz beschrieben, und zwar auf Grundlage der Einträge im gedruckten Handschriftenkatalog der isländischen Nationalbibliothek; dabei werden meist deutlich weniger Informationen gegeben als im gedruckten Katalog, so daß nicht erkennbar ist, worin der eigentliche Gewinn bestehen soll. Von den 94 aufgelisteten laienastrologischen Handschriften werden dann zwölf ausgewählt und näher untersucht. Darauf, nach welchen Kriterien diese Auswahl erfolgt, wird nur kurz eingegangen. Auf S. 143-144 heißt es:

Eine repräsentative Auswahl der besagten Texte wird im Folgenden vorgestellt und in den Kontext der jeweiligen Handschrift eingeordnet. Pro Untergattung werden einige Textzeugen ausgewählt, um den Grad der Varianz (von unwesentlichen Varianten zu Mehrfassungen) darzustellen.

\footnotetext{
${ }^{17}$ Hierzu heißt es nur(Bauer 2015: 142): „Die Handschriftenkataloge derArnamagnäanischen Sammlung verzeichnen ebenfalls eine Reihe von Handschriften des laienastrologischen Schrifttums. Diese Texte bedürfen jedoch keiner gesonderten Behandlung, da es sich dabei ebenfalls [ergänze um] isländische Papierhandschriften aus derselben Zeit handelt, die von den hier untersuchten Textzeugen im Wesentlichen nicht abweichen."

${ }^{18}$ Das „Verzeichnis“ auf S. 445-446 listet die Handschriften in alphabetischer Reihenfolge nach dem Beginn der Handschriftensiglen (ÍB - ÍBR - JS - Lbs) auf, allerdings mit der Ausnahme, daß die vier aufgeführten Handschriften der Rímbegla in der Reihenfolge, die ihre Siglen im Handschriftenkatalog der Isländischen Nationalbibliothek haben (Lbs - JS - ÍB), angeordnet sind. Das „Ausführliche Verzeichnis“ auf S. 447-469 hingegen listet alle Handschriften in der Reihenfolge, die die Siglen in diesem gedruckten Katalog haben (Lbs - JS - ÍB - ÍBR), auf.
} 
Und wenig später (S. 144):

Die hier dargestellten Texte sind nach rein pragmatischer Natur wie der [sic] Erhaltungszustand der Textträger gewählt worden: Ausgewählt wurden Schriften und Manuskripte, die vollständig und verhältnismäßig gut erhalten sind, damit eine lückenlose Abschrift erfolgen konnte.

Die vorliegende Untersuchung gibt also weder einen Gesamtüberblick über das einschlägige Material von um oder über 200 Handschriften, noch wird schlüssig erklärt, weshalb die für die Bearbeitung ausgewählten zwölf Handschriften, die nicht einmal sechs Prozent der Gesamtmenge der erhaltenen Textzeugen ausmachen, repräsentativ sein sollen für die Überlieferung dieser Texte - der Umstand, daß ein Manuskript gut erhalten und gut lesbar ist, bedeutet ja nicht unbedingt, daß ein in diesem Manuskript überlieferter Text die Überlieferung dieses Textes besonders gut repräsentiert.

Natürlich läßt sich auch Positives über die vorliegende Arbeit sagen: Das Thema ist neu und interessant, soll doch eine bislang weithin unbeachtete Gruppe von Texten der (noch immer nur wenig erforschten) isländischen Literatur der postreformatorischen Zeit untersucht und zugänglich gemacht werden, das Untersuchungsprogramm ist ambitioniert, der Seitenumfang des Buches macht deutlich, daß die Durchführung dieser Untersuchung mit einem großen Zeitaufwand verbunden war.

All das ändert jedoch nichts an der Tatsache, daß diese Arbeit von einer erschreckenden Laienhaftigkeit in philologicis islandicis zeugt und insgesamt weit unter dem Niveau bleibt, das man von einer wissenschaftlichen Arbeit erwarten darf und muß. Die gravierendsten Defizite und Mängel wurden bereits benannt. Zusätzlich wäre noch anzumerken, daß offensichtlich niemand Korrektur gelesen hat, bevor die Arbeit gedruckt wurde: das Buch ist voller Druckfehler (auch im deutschen Text), die Bibliographie ist schludrig, in Fußnoten wird auf Literatur verwiesen, die in der Bibliographie nicht verzeichnet ist, die Kapitelzählung stimmt nicht, etc. etc. Dem Vorwort ist zu entnehmen, daß es sich bei dem vorliegenden Buch um die überarbeitete Fassung der drei Jahre zuvor eingereichten Habilitationsschrift handelt - man wagt gar nicht, sich vorzustellen, wie das Werk vor dieser Überarbeitung für den Druck ausgesehen haben mag.

Bleiben abschließend noch folgende Fragen:

Erstens: Wie konnte es geschehen, daß eine so offensichtlich unzulängliche Arbeit von einer traditionsreichen deutschen Universität als schriftliche Habilitationsleistung anerkannt wurde? Warum hat man, wenn am 
Ort die zur Beurteilung dieser speziellen Arbeit notwendige islandistische Kompetenz nicht vorhanden war, keinen kompetenten externen Gutachter aus Island herangezogen?

Zweitens: Wie konnte es geschehen, daß die Arbeit in der vorliegenden Form in einer renommierten, auf Nordistisches spezialisierten Schriftenreihe publiziert wurde? Hat man die Arbeit nicht gelesen, bevor sie zur Publikation angenommen wurde? Habilitationschriften unterliegen in der Regel nicht der Publikationspflicht. Mit dem Druck dieses Buches in dieser Form hat man niemandem einen Gefallen getan.

\section{Literatur}

Bauer, Alessia (2015). Laienastrologie im nachreformatorischen Island. Studien zu Gelehrsamkeit und Aberglauben (=Münchner Nordistische Studien 21). München.

Brenner, Sebastian (1559). Das gro $\beta$ Planeten-Buch, sampt der Geomanci, Physiognomi vnd Chiromanci. Straßburg.

En skiøn Planete-Bog, huor udi bescriffuis de siu Planeters met de Tolff Tegns Natur oc Complex, meget herligen affmalede, oc andre flere Stycker, som her ocsaa tilhøre (1625). Kopenhagen.

En skiфn Planete-Bog, hvor udi beskrivess de syv Planeters med de Tolv Tegns Natur oc Complex. Meget herligen afmalede, oc andre fleere Stykker, som her ogsaa tilhфre (1764). Kopenhagen.

Kristján Árnason (2013). Stíll og bragur. Um form og formgerðir íslenskra texta. Reykjavik.

Merk, Angelika (2018). Blockbücher des 15. Jahrhunderts. Artefakte des frühen Buchdrucks (=Diss. Universität Konstanz 2015). Berlin.

Ordbog over det danske Sprog 2 (1920). Kopenhagen.

Páll Eggert Ólason (1927). Skrá um handritasöfn Landsbókasafnsins 2. Reykjavik.

Schneider, Karin (1988). Deutsche mittelalterliche Handschriften der Universitätsbibliothek Augsburg. Die Signaturengruppen Cod. I.3 und III.1 (=Die Handschriften der Universitätsbibliothek Augsburg. Reihe 2. Die Deutschen Handschriften 1). Wiesbaden.

Stefán Karlsson (2016). „Skal udgiverens arbejde være omsonst?““. Opuscula 14 (=Bibliotheca Arnamagnæana 48). Kopenhagen: 315-323.

Stegemann, Viktor (1944). Aus einem mittelalterlichen deutschen atronomischastrologischen Lehrbüchlein. Eine Untersuchung über Entstehung, Herkunft und Nachwirkung eines Kapitels über Planetenkinder (=Prager Deutsche Studien 52). Reichenberg. 


\section{Online-Literatur}

https://sarpur.is/Adfang.aspx?AdfangID=347931

https://www.thjodminjasafn.is/syningar-vidburdir/adrar-syningar/gripurmanadarins/en-skion-planete-bog-stjornuspadomsbok-fra-1764

https://handrit.is/en/manuscript/view/is/JS08-0392

\section{Summary}

The Icelandic paper manuscript JS 392 8vo, written in the middle of the eighteenth century, contains among other texts a poem titled "Sjö plánetur í ljóðmælum" ('The seven planets in verse'), in which the influences of each of the seven classical planets - Saturn, Jupiter, Mars, Sun, Venus, Mercury and Moon - on the looks and character of people born under their respective reign are listed.

This article gives a transcription of the manuscript text of the poem as well as a normalised version in modern Icelandic orthography plus a German prose translation. The fifteen eight-line stanzas follow the rules of traditional Icelandic poetry with alliterations and internal rhymes.

The manuscript JS 3928 vo contains also a prose text on the influences of the planets on people's looks and character, but it is obvious that there is no direct relationship between the poem and this prose text.

There are, however, very close affinities between the poem and a prose text preserved in the manuscript JS 74 8vo, written in Iceland around the year 1740, and there can be no doubt that the poem's author used a prose source closely related to the text in JS $748 \mathrm{vo}$.

This prose text, as preserved in JS $748 \mathrm{vo}$, is a literal translation from a Danish printed book (En skiøn Planete-Bog, ed. 1625, 1686, 1710 and later), which in turn goes back to the German Planetenbuch tradition (printed editions from 1544 onwards).

The excursus is based on a critical reading of Alessia Bauer's Habilitationsschrift (Laienastrologie im nachreformatorischen Island. Studien zu Gelehrsamkeit und Aberglauben, 2015), in which the author tackles a very interesting theme - but apparently without the necessary philological skills, so that the outcome is sadly disappointing.

Keywords: Text edition, Icelandic manuscripts, Icelandic poetry, Early modern period, Popular astrology.

Hubert Seelow

Friedrich-Alexander-Universität Erlangen-Nürnberg (FAU)

Department Germanistik und Komparatistik

hubert.seelow@gmx.net 


\title{
Instances of loanword/native word textual variation in the manuscript transmission of Egils saga Skallagrímssonar and Gísla saga Súrssonar
}

\author{
MATTEO TARSI
}

\section{Introduction}

This article is concerned with intrastemmatic variation in two sagas of the Icelanders, Egils saga and Gísla saga. ${ }^{1}$ The point of departure for this research is a comprehensive investigation of the interplay between loanwords and native words in Old and Middle Icelandic (Tarsi [forthcoming]). ${ }^{2}$ Here, the focus will be on a handful of case-studies which can accomodate a primarily philological nature and which involve elements

\footnotetext{
${ }^{1}$ Intrastemmatic variation here is defined as the variation between a loanword and a synonymic native lexeme in a given locus of a text in different manuscript witnesses preserving that very same text. The core idea of the present article was presented at GLAC 22 (2016), the annual conference of the Society for Germanic Linguistics, with the title "Loanwords vs. Native Words in Old and Middle Icelandic: The coexistence and competition of (quasi-) synonymic couples in the texts and the lexicon".

2 The research project Loanwords and native words in Old and Middle Icelandic (20162020) documents the coexistence and competition of loanwords and their respective native synonyms across all typologies of Icelandic literary prosa in the period before the rise of purist attitudes in Iceland (end of 16th/beginning of 17th c.). In 2018 the project was awarded a two-year grant from the University of Iceland Research Fund (Háskólasjóður Eimskipafélags Î́slands). I wish to thank Andrew Wawn (University of Leeds) for having corrected my English and Dario Bullitta (University of Turin) for the fruitful discussion we had at the XX Seminario Avanzato in Filologia Germanica (16-18 September 2019) on a portion of what is presented here.
}

Tarsi, Matteo. 2019. Instances of loanword/native word textual variation in the manuscript transmission of Egils saga Skallagrímssonar and Gísla saga Súrssonar.

Scripta Islandica 70: 87-104.

(C) Matteo Tarsi (CC BY)

DOI: https://doi.org/10.33063/diva-400605 
to which of the two lexemes, loanword or native word, ${ }^{3}$ is the original reading. The methodological approach adopted throughout the analysis takes into consideration both internal and external elements concurring to the right evaluation of a textual variant. One caveat is in order at the outset, namely that variation of loanwords and native words is unrelated to any sort of purist attitude. This holds true both for the original composition of the texts under discussion and for their later copies, on which the present discussion is based.

\section{A single case in Egils saga: buklari 'buckler' and skjoldr 'shield'}

A passage in Egils saga $a^{4}$ describing Egill's combat gear (ÍF II: $106^{14}$ ) is particularly interesting, in that the text shows intrastemmatic variation:

${ }^{3}$ The typological model adopted in the present research envisages four categories of native words, namely structural calque, semantic calque, neoformation and inherited word. Brief definitions of these terms are as follows:

structural calque: a word, usually a compound in the case of Icelandic, whose structure parallels the grammatical and semantic relationship between the constituents of the source word. A structural calque is a word-by-word (or morpheme-by-morpheme) translation of a source word.

semantic calque: this involves the reproduction of a previously unknown meaning in a word of native stock.

neoformation: a word which cannot be formally traced back to a foreign model, although it may reproduce the semantics thereof, and is limited to the lexical stock of a given language, i.e. it has been coined in that language.

inherited word: a lexical item which satisfies the following two conditions: 1) its formal evolution can be either documented or reconstructed in a given language or its direct ancestor; 2) its semantics are explicable in terms of internal reconstruction. The chronological time-limit for words under consideration is here fixed to PGmc. Words which are derived by means of internal process, usually have cognates in other Germanic languages and do not show an obvious link to any foreign source, are treated as inherited lexemes in this study.

${ }^{4}$ Egils saga is preserved in three different versions: A, B and C, whose main witnesses are: AM 132 fol. (A version, Möðruvallabók, M, 1330-1370, Bjarni Einarsson 2001); Cod. Guelf. 9.10 Aug. 4to (B version, W, ca. 1350, Schwabe 2015); and AM 462 4to ( $\mathrm{K}^{1}$ and $\left.\mathrm{K}^{3}, 1620-1670\right)$ and $\mathrm{AM} 453$ 4to ( $\mathrm{K}^{2}, 17$ th c.) (C version, Chesnutt 2006). These last two manuscripts are also known as Ketill's books after Árni Magnússon's maternal grandfather Ketill Jörundarson; $\mathrm{K}^{3}$ is a 17 th-century addition to $\mathrm{K}^{1}$ with a hand different from that of Ketill. This addition was due to the loss of folia at different places (cf. Chesnutt 2006: xxiv). In addition to these main manuscripts, ten fragments have independent value. These have been gathered together in AM 162a fol. and are usually referred to by means of Greek 


\begin{tabular}{|c|c|c|}
\hline $\begin{array}{l}\text { A version } \\
(\mathrm{M}, \mathrm{Bjarni} \text { Einarsson } \\
\left.\text { 2001: } 60^{11}\right)\end{array}$ & $\begin{array}{l}\text { B version } \\
(\mathrm{W}, \text { Schwabe 2015: } \\
\left.225^{6-7}\right)\end{array}$ & $\begin{array}{l}\text { C version } \\
\left(\mathrm{K}, \text { Chesnutt 2006: } 52^{8-9}\right)\end{array}$ \\
\hline $\begin{array}{l}\text { Egill hafði vapn sín. } \\
\text { Suerð ok kesíu ok } \\
\text { buklara· }\end{array}$ & $\begin{array}{l}\text { hann hafði ok vapn sin } \\
\text { oll. }\end{array}$ & $\begin{array}{l}\text { hann hafde vopn sïn } \varnothing l 1 \text {, } \\
\text { sverd og kesju, hjälm og } \\
\text { skjølld. }\end{array}$ \\
\hline
\end{tabular}

The loanword buklari is of particular interest, for it only occurs once in the whole text of $\mathrm{M}$ and is not found in any of the other fragments of the saga. It can thus be said that buklari is a hapax legomenon in the transmission of this saga. The question that arises is whether buklari can be considered an original reading in comparison to those others encountered and with particular reference to the $\mathrm{C}$ version, where the native word skjoldr is used instead. ${ }^{5}$

According to Jón Helgason's stemma (cf. Chesnutt 2005: 229), the B and $\mathrm{C}$ versions derive from a lost exemplar, which in turn derives from the same manuscript as the A version. In order to shed light on the present case, it is notable, firstly, that $\mathrm{W}$ preserves a text which is somewhat shorter than the versions in $\mathrm{M}$ and $\mathrm{K}$. This is an important feature of $\mathrm{W}$, which consistently shortens the text of the saga (cf. Finnur Jónsson 1886-1888: xx). The portion of text under discussion has infact features similar to the two examples adduced by Finnur Jónsson (1886-1888: xxi) to make his point. The lectio in $\mathrm{W}$ can thus be considered as spurious for it follows a general tendency encountered in the B version of the saga

letters $(\alpha-\chi)$. Of these fragments, the oldest is $\theta$, from 1240-1260 (A version). The other fragments are grouped as follows: $\eta$ (ca. 1450-1475), $x$ (15th c.) (A version); $\beta$ (ca. 1350), $\gamma$ (ca. 1300-1325), $\delta$ (ca. 1300), $\zeta$ (1250-1300), ı (15th c.) (B version); $\alpha$ (16th c.), $\varepsilon$ (ca. 1400) (C version). Among other manuscripts, Stock. perg. 7 4to (ca. 1300-1325) has independent value and preserves a text of the B class (for further discussion about the manuscripts of Egils saga see Finnur Jónsson 1886-1888: i-xxix).

${ }^{5}$ OIcel. buklari 'buckler' is first attested in a pula believed to be from the 12th century (Skjald.AI: 667). The word is thought to derive from Middle Low German (bokelēr), where it is a loan from OFr. (escut) bucler, maybe from medieval Latin *(scutum) buccularium (cf. IeW, $\mathrm{AeW}, I \mathrm{O}$, s.v. buklari). The word is not found in any other skaldic text, whereas its attestations in prosa are from the 13th century (cf. ONP, s.v. buklari and the remark by Gurevich 2017: 824). This suggests that either the word was inserted in the bula at a later time, or that the pula itself is somewhat younger.

OIcel. skjolddr 'shield' is attested from the 10th century and is a word of native stock. The word has well-attested cognates in other branches of the Germanic language family: Got. skildus, OE scield, OS skild, OHG scilt 'shield'. The Germanic lexemes all go back to PGmc *skeldu- 'shield'. 
and thus does not constitute a stylistic departure. The lost exemplar $a$, from which the $\mathrm{B}$ and $\mathrm{C}$ versions derive, can be said to have had a text which, if anything, was nearer to that of $\mathrm{K}$. This is further confirmed by the fact that the same wording as in $\mathrm{K}$, with the exception of the word oll, is preserved in the $\delta$ fragment (ed. Kjeldsen 2005: 147), which contains a B class text (cf. Finnur Jónsson 1886-1888: 131 and apparatus). As for the reading hjalm ok skjold in $a(=\mathrm{K} \delta)$, it may be noted that it has a particular rhythm when combined with the preceding sverð ok kesju. It could thus be suggested that the word hjalmr was added in $a$ for the sake of completeness, for Egill did indeed wear a helmet, but also for rhythmical (i.e. textual) reasons. However, the opposite could also have been the case; namely, that the word hjalmr was indeed part of the original text but was omitted from the A version. There are thus elements in favor of either interpretation, although the latter seems more plausible in light of a comparison with the description of Egill's gear at the beginning of chapter 45 , where, conversely, the shield is not mentioned. ${ }^{6}$

We are thus left with chosing between buklari and skjoldr. As we have no other A class witness to help shed light on this issue, relevant internal as well as external factors need to be considered. Firstly, it was noted that buklari occurs just once in the manuscript in which $\mathrm{M}$ is preserved, AM 132 fol. By contrast, the word skjoldr occurs forty-five times in M. Secondly, the word buklari occurs twice in the manuscript as a whole, once as a simplex (Egils saga) and once compounded with targa 'shield' (Njáls saga), whereas skjoldr is used 197 times as a simplex and also twice in a compound with targa (Njáls saga) (see MvB, s.vv. buklari, skjöldr, törgubuklari, törguskjöldr). Thirdly, the word buklari occurs just three times in the whole corpus (cf. Olísl., s.v.): as the previously mentioned compound in Njáls saga, and as a simplex in Egils saga and Grettis saga, although in the latter saga it does not constitute a word pair as the buckler in question is never referred to as skjoldr. However, data from OlÍsl. should be used with caution, for it treats the sagas as printed texts, not as manuscripts. Finally, it may be noted that buklari occurs frequently in narrative genres such as Kings' and Chivalric sagas (cf. ONP, s.v. buklari), whereas it appears only once in skaldic poetry (see footnote 5).

When all this evidence is considered, the question arises as to which

\footnotetext{
${ }^{6}$ Not far from the description under discussion (Ch. 43) Egill's gear is listed again. There (Ch. 45) the word hjalmr appears in all the versions of the saga (M, Bjarni Einarsson 2001:

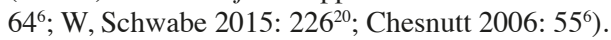


of the two readings, buklari or skjoldr, is more likely to be the original one. As has been shown, analysis of the textual tradition suggests that Egill's gear had to be listed in that particular locus of the saga (lectiones of $\mathrm{M}$ and $a(=\mathrm{K} \delta)$ but not $\mathrm{W})$. Now, both buklari and skjoldr would have been meaningful choices. The loanword, albeit used anachronistically in the saga narration, ${ }^{7}$ was adopted in Icelandic before the purported date of composition of the saga. However, on closer scrutiny, buklari seems an implausible reading here, in the light of its infrequent use in the saga, in manuscript copies of the saga, and in the sagas of the Icelanders overall (cf. also the general comment on this topic in West 1973: 51). The present analysis suggests that buklari may have substituted skjoldr in that particular locus of Möðruvallabók. It can thus be proposed that skjoldr is the original reading.

\section{A few cases in Gísla saga}

Gísla saga ${ }^{8}$ includes a certain number of word pairs which alternate loanword and native word intrastemmatically. Also, the manuscript tradition of this particular saga has received much attention both in early and more recent times. ${ }^{9}$ Guðni Kolbeinsson and Jónas Kristjánsson (1979) provide

\footnotetext{
${ }^{7}$ That buklari was not in use in the North at the time when Egils saga takes place is reported by Hjalmar Falk (1914: 133), who is most probably the source of Sigurður Nordal's footnote in his edition of Egils saga in Íslenzk fornrit (IF II: $106 \mathrm{fn}$ 1). Falk (1914: $133 \mathrm{fn}$ 1) notes that the word is used anachronistically in Grettis saga but adds that bukl could have been acquired in Icelandic earlier than buklari. for the word imunbukl 'shield' occurs in a lausavísa by Grettir Ásmundarson.

${ }^{8}$ Gísla saga is preserved in three different versions; S (longer version, Dan. større), M (shorter version, Dan. mindre), and B (fragmentary version, Dan. brudstykke). The main difference between $\mathrm{S}$ and $\mathrm{M}$ relates to the length of the introductory section. Scholarly debate about the relationship and origin of these three versions, and particularly of $S$ and $\mathrm{M}$, has long been part of discussion about this saga, and also, more generally, about philological practice itself (for an overview see e.g. Pórður Ingi Guðjónsson 2010 and Lethbridge 2013). The longer version (S) is preserved in two 18th-century paper copies of a lost vellum manuscript, the so-called Membrana Regia Deperdita (Loth 1960). These copies, AM 149 fol. and NKS 1811 fol., were directly and independently made from the Membrana Regia Deperdita in two different periods, the former ca. 1700 and the latter ca. 1780. Accordingly, they both have independent value. The main manuscript for the shorter version (M) is AM 556a 4to (last quarter of the 15th century). The B version is preserved as four vellum folia (2r-5v) under the shelfmark AM 445c I 4to (ca. 1390-1425).

${ }^{9}$ E.g. Konrád Gíslason (1849), Finnur Jónsson (1929), Björn K. Pórólfsson (1943, ÍF VI),
} 

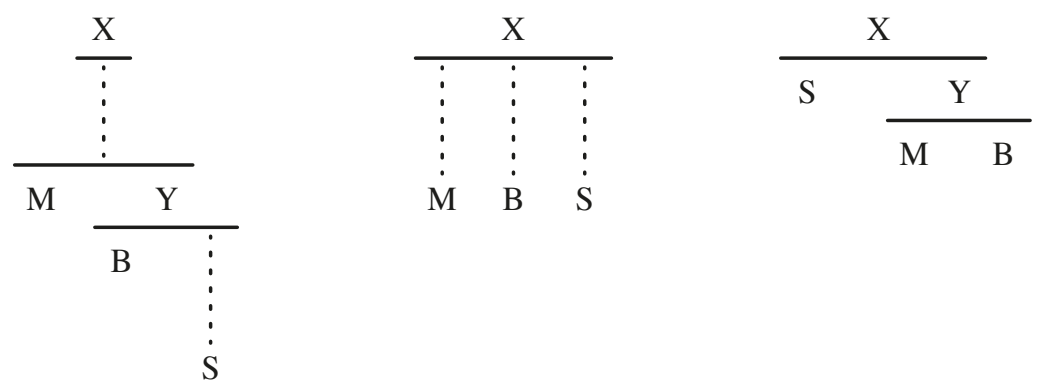

Fig. 1. The stemmata proposed by Finnur Jónsson (1929, left), Jón Helgason (1956, middle) and Guðni Kolbeinsson and Jónas Kristjánsson (1979, right)

a revision of the stemmata proposed by Finnur Jónsson (1929) and Jón Helgason (1956), together with a reappraisal of critical lectiones, also with reference to Björn K. Pórólfsson's edition. The outcome of such a reassessment is a set of stemmatic rules that seek to distinguish between original and spurious readings (Guðni Kolbeinsson and Jónas Kristjánsson 1979: 143-144, my translation):

1 If either $\mathrm{M}$ or $\mathrm{B}$ agrees with $\mathrm{S}$, that reading is to be considered original.

2 If each version of the saga preserves a different reading, it is likely that $\mathrm{S}$ preserves a more original text than do $\mathrm{M}$ or $\mathrm{B}$. Moreover, $\mathrm{M}$ preserves a more original text than $\mathrm{B}$.

3 If $\mathrm{M}$ and $\mathrm{B}$ agree against $\mathrm{S}$ it cannot be determined which of the two readings is original, for $\mathrm{M}$ and $\mathrm{B}$ stand for a lost manuscript $\mathrm{Y}$ against $\mathrm{S}$.

4 It should be noted that $y$ preserved a shortened text. Moreover B preserves a relatively shorter text than $\mathrm{M}$. As a general rule, the more complete readings in $\mathrm{S}$ are to be regarded as original.

5 If the exemplars of S, AM 149 fol. and NKS 1181 fol., preserve different readings, these should be compared where possible to those in $\mathrm{M}$ and/or $\mathrm{B}$, and the particular reading of $\mathrm{S}$ which is paralleled in $\mathrm{M}$ and/or B should be chosen.

Jón Helgason (1956), Agnethe Loth (1956), Guðni Kolbeinsson and Jónas Kristjánsson (1979), Lethbridge (2010, 2013), Pórður Ingi Guðjónsson (2010). 
At this point, it is interesting to test this set of rules, and thus the stemma from which they are derived (Fig. 1, right), against the stemmata proposed instead by Finnur Jónsson (1929, Fig. 1, left) and Jón Helgason (1956, Fig. 1, middle). The purpose of the following test is to see whether the intrastemmatic variation between loanwords and native words can say something about the validity of the stemmata proposed for Gísla saga, i.e. whether it provides further evidence for one stemma over the others. The word pairs on which the present discussion focuses are AMBÁTT - PÝ 'slave-woman', BUFFEIT - KINNHESTR 'buffet, slap', FRÍA - FIRRA 'to free' and KOMPÁNN - FÉLAGI 'companion, fellow, comrade'. The three stemmata are reproduced here as they appear in Guðni Kolbeinsson and Jónas Kristjánsson's article.

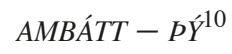

S (Loth 1960: 537-8)

M (Finnur Jónsson 1929: 46 ${ }^{4-5}$ )

$\mathrm{B}$ enn Bothilldr het py hans eðr ambatt

enn ambattin het Bothilldr

$\div$

In the case of ambátt and $p y$, we can unfortunately use only two of three manuscript witnesses. However, the good news is that $\mathrm{S}$ and $\mathrm{M}$ have in common a considerable part of the text under discussion. If the comparison between $\mathrm{S}$ and $\mathrm{M}$ in this locus is tested against the three stemmata given above, the result will be the same, i.e. that py hans is an addition in $\mathrm{S}$. In particular, Finnur Jónsson's view that M preserves a text nearer to the original than $\mathrm{S}$ yields that py hans was later added to S. In Jón Helga-

${ }^{10}$ OIcel. ambátt 'slave-woman' is first found in Icelandic in a 9th-century kvað $i$ by the skald Porbjorn Hornklofi. The word is undoubtedly a very ancient loan in Germanic, as it occurs already in Gothic (andbahts 'servant'). The word is undoubtedly a Celtic loan in Germanic, as we know from Latin sources (Sextus Pompeus Festus, 2nd c. AD) that Lat. ambactus (<Gaul. ambaxtos, cf. Lewis/Short, s.v. ambactus and EdPCelt., s.v. *ambaxto-) was used by Ennius (3rd/2nd c. BC) instead of Lat. servus. Caesar in his Commentarii de bello Gallico (1st c. BC) also uses the word as a loan.

OIcel. pý 'slave-woman' is a secondary form of OIcel. pír 's.m.' (< PGmc pegwijō-, cf. Got. piwi), created analogically from the stem of cases other than the nominative singular, as is the case with meyja 'maiden' in relation to maer (<PGmc *magwijō-, cf. Got. mawi). The word is thus an inherited lexeme in Icelandic. Other cognates of this word in the Germanic language family are OE peów, OS thiu, OHG diu 'female servant'. Cf. also Got. pius, OE peów (masc.) 'servant' and pewar 'servitor, retainer' (N KJ55, ca. 400 < PGmc *begwa-). 
son's stemma, however, the three versions of the saga are put on the same level, for he cannot find enough elements that confirm Finnur Jónsson's stemma. Jón Helgason argued that it was not possible to consider all the agreeing lectiones of $\mathrm{B}$ and $\mathrm{S}$ as secondary to that of $\mathrm{M}$, as they were just as likely to be primary. In our case, we do not have B to compare with $\mathrm{M}$ and $\mathrm{S}$. A shared portion of text between $\mathrm{M}$ and $\mathrm{S}$ ought to be considered original, and hence, the deviation of $\mathrm{S}$ from the lectio of $\mathrm{M}$ should be considered spurious. According to Guðni Kolbeinsson and Jónas Kristjánsson's pentalogue, rules 1 and 4 must be taken into account. Rule 4 suggests that more complete readings in $\mathrm{S}$ are to be considered as original. As regards the question of loanword and native word, rule 1 applies in that $\mathrm{M}$ agrees with $\mathrm{S}$ and employs the word ambátt, and thus any agreement of either $\mathrm{M}$ or $\mathrm{B}$ with $\mathrm{S}$ gives an original lectio.

Following the given manuscript evidence, it is safe to assume that ambátt constitutes an original reading here. The question is whether $\mathrm{S}$ actually preserves the original lectio or whether the more concise reading of $\mathrm{M}$ is preferable. A major trend in Gísla saga scholarship has been to consider the longer version as secondary to the shorter version. In Björn K. Pórólfsson's 1943 edition, the editor goes as far as calling M and S, E and Y respectively, i.e. eldri 'older' and yngri 'younger', thus classifying the two versions according to relative chronology of their witnesses. I want to focus here on a stylistic feature of the reading preserved in $\mathrm{S}$, namely the synonymic dittology pý hans eðr ambátt. ${ }^{11}$ Synonymic dittologies are also found elsewhere in the text of Gísla saga. A comparison between $\mathrm{M}$ and $\mathrm{S}$ concerning synonymic dittologies which use the explanatory conjunction eða reveals that such a stylistic trait is not peculiar to either version of the saga. However, where the $M$ version appears to have such a kind of dittology, the corresponding locus in $\mathrm{S}$ is, if not the same, regularly shorter. ${ }^{12}$ This clashes somewhat with the fact

\footnotetext{
${ }^{11}$ A synonymic dittology is a figure of speech in which two words of similar or identical semantic content are linked by the coordinative conjuction and (OIcel. ok, Icel. og) or the disjunctive/explanatory conjunction or (OIcel./Icel. $e ð(u) r, e ð a)$ in order to convey a certain meaning, along with a pleonastic stylistic reinforcement. Synonymic dittologies are one of the chief ways in which loanwords and respective native synonym may be paired in a given text.

${ }^{12}$ víg Vésteins eðr mord (M, Finnur Jónsson 1929: $20^{9}=\mathrm{S}$, Loth 1960: 2912)

hverr sterkastr er eðr mestr atgjǫrvimaðr er (M, Finnur Jónsson 1929: 2321-22)

hverr sterkastr var ok mestr atgervimadr (S, Loth 1960: $33^{5-6}$ )

og urðu pví eigi tekin pau ráð sem dygði eða porf var á (M, Finnur Jónsson 1929: $27^{20}$ and apparatus)
} 
that the dittology pý hans eðr ambátt is preserved in $\mathrm{S}$ instead of $\mathrm{M}$. This is not an isolated example, as $\mathrm{S}$ preserves the dittology sýruker ... eða stokkaker (Loth 1960: 13 ${ }^{19}$ ) whereas M has sýruker tvo (Finnur Jónsson 1929: $4^{10}$ ). This last example, in particular, seems close to that of ambátt and $p y$, as it is the second element of the dittology to be added. Ultimately, it is impossible to establish which of the two readings is the original. It is possible, however, that it is the longer reading that has been augmented, and this may hold true also for the longer readings of $\mathrm{M}$ against those of $\mathrm{S}$ enumerated in normalized orthography in footnote 12 .

$$
\text { BUFFEIT - KINNHESTR }{ }^{13}
$$

S (Loth 1960: 3324)

Porgrimr hleypr at honum oc gefr honum kinnhest

M (AM 556a 4to, f. 59v3, cf. Finnur Paa gengr Porgrimr at honum ok slarr Jónsson 1929: $24^{15}$ and apparatus) hann buffeit mikit

B (Jón Helgason 1956: 40 12-13) porgrimr hleypr at honum oc slaer hann kinnhe [st]

If Finnur Jónsson's stemma is adopted in this case, the agreement between $\mathrm{B}$ and $\mathrm{S}$ on kinnhestr would require an evaluation of which of the two, buffeit mikit or kinnhestr, is more likely to have been the original reading, since B and S are witnesses of a lost exemplar Y. In the main text of his edition, Finnur Jónsson amends the text and substitutes buffeit mikit for kinnhestr. In fact, he notes elsewhere that "M kan være og er på sine

og tóku menn af pví eigi svá skjótt pað ráð er hlýddi (S, Loth 1960: 36-3)

Gísli spyrr Porkel bróður sinn ráða eðr hvat hann legði til með honum eðr hvort hann vill nokkra ásjá veita honum (M, Finnur Jónsson 1929: 34 ${ }^{17-18}$ )

Gísli spyrr Porkel enn hvat hann skal nú ráðs taka eða hverja ásjá hann vill honum veita (S, Loth 1960: 42 $19-21$ )

að húsi einu eðr skála (M, Finnur Jónsson 1929: 40-7)

að skála miklum (S, Loth 1960: 47²)

${ }^{13}$ OIcel. buffeit 'buffet' is first attested in Icelandic in Gísla saga, i.e. ca. 1250. The word is believed to be a loan from ME buffet (IeW, IOb, s.v. buffeit, and Eyvindur Eiríksson 1977: 46). The Middle English word is a loan from OFr. buffet, bouffet, itself a diminutive of buffe 'blow, stroke' (cf. OED, s.vv. buffet and buff). Fr. buffet 'sideboard, side-table, refreshments (by metonymy)' (= Eng. buffet) is a homophone.

OIcel. kinnhestr 'slap' is a neoformation attested since ca. 1200 in Icelandic. The word is only found in North Germanic (ODan. kinhast, OSw. kinhäster). The semantic relationship between the constituents of this word is obscure and requires further etymological inquiry. 
steder ændret af afskrivere" (Finnur Jónsson 1923: 454 fn 1). In chosing between the two, it is probable that Finnur Jónsson's decision depended on the idea that kinnhestr had to be more original because it is an endogenous word. A purely speculative argument in favor of buffeit can be made, as was pointed out to me by Klaus Johan Myrvoll in 2016, whom I thank for having drawn my attention on this specific issue. The argument is that buffeit could be considered an original reading because a Middle English loan (OIcel. buffeit < ME buffet < OFr. buffet, bouffet, Eyvindur Eiríksson 1977: 46) would be perfectly plausible for the period in which the saga is considered to have been composed (ca. 1250). In Jón Helgason's approach, instead, the witness of B is crucial because the agreement of two versions over the third gives the original reading or, at least, the most original that may be surmised. According to Guðni Kolbeinsson and Jónas Kristjánsson's method rule 1 applies and it yields the same result as Jón Helgason's; the chief difference is that the agreement in Guðni and Jónas' approach has necessarily to be between two versions, each of which has to be in a different branch of the stemma. Here, S and B agree against $\mathrm{M}$, thus giving kinnhestr as the original reading. An argumentum ad absurdum can also be made in order to further verify this result. If buffeit mikit were the original reading, then kinnhestr had to be corrupted into the two other versions, $\mathrm{S}$ and $\mathrm{B}$. This is clearly at odds with the philological principle invoked above for the similar case of buklari and skjqldr. Here, also, buffeit is not a plausible reading for exactly the same reasons as in the case of buklari. The $\mathrm{M}$ version of Gísla saga is in fact the only instance of this word in the whole Old Icelandic corpus (cf. ONP, s.v. buffeit). ${ }^{14}$

\footnotetext{
${ }^{14}$ In the same portion of text there appears intrastemmatic variation between the verbs hlaupa (SB): ganga (M) and slá (MB) : gefa (S). According to Guðni Kolbeinsson and Jónas Kristjánsson's pentalogue, hlaupa can be said to be an original reading against ganga (rule 1). Jón Helgason's stemma would yield the same result, whereas Finnur Jónsson's would need us to weigh the two variants individually, i.e. as witnesses of two branches of the tradition. On the readings slá : gefa, rule 3 says that the most original reading cannot be determined. Jón Helgason's stemma would automatically pick slá and so would Finnur Jónsson's. If we accept the arguments of Guðni Kolbeinsson and Jónas Kristjánsson, then the reading slá could be considered the better choice by virtue of the fact that slá is lectio difficilior in comparison to gefa, given that both verbs convey the same general meaning, i.e. they are both meaningful variants.
} 


$$
\text { FRÍA - FIRRA }{ }^{15}
$$

S (Loth 1960: 5622)

149 fría : 1181 firra

M (Finnur Jónsson 1929: 50 ${ }^{14-15}$ ) firra

B

$\div$

In the present case, both Finnur Jónsson's and Jón Helgason's stemmata would yield firra as the original reading. According to Guðni and Jónas' pentalogue, rule 5 applies in this case. Here, the two witnesses for $S$ diverge in that 149 preserves the word fría, whereas 1181 employs firra. Without doubt, the original lectio appears to be firra, since it is shared by at least one witness for $\mathrm{S}$ and $\mathrm{M}$. A linguistic criterion can also suggest a further element that would corroborate the present choice between variants, namely that OIcel. fría is a late loanword, whose first attestation is in Halldórs páttur Snorrasonar hinn fyrri (14th c.), as preserved in the younger part of Flateyjarbók (GKS 1005 fol. from ca. 1450-1500). Moreover, in the manuscript tradition of that páttur, the verb alternates with frelsi gefa in the oldest part of the same manuscript (from ca. 13871395), as noted by Veturliði Óskarsson (2003: 40-41). Such a loanword is not likely to have been part of the original text of this saga, which is thought to have been composed ca. 1250 .

$$
\text { KOMPÁNN - FÉLAGI }{ }^{16}
$$

S (Loth 1960: 4324)

M (Finnur Jónsson 1929: 36²)

B (Jón Helgason 1956: 552-3) pa snyR Steinn aptr i moti peim felogum sinom

$\mathrm{Nu}$ snyrr Steinn i mote felaugum sinum

nu snyr steinn i moti sinum kumpanum

\footnotetext{
${ }^{15}$ OIcel. fría 'to free' is first attested in Icelandic in works from the 14th century. AeW and ÍOb consider the word to be a loan from MLG vrien 's.m.', whereas IeW (s.vv. prēi- and $f r i$ ) claims that the word is native to Icelandic, along with the adjective frír. The relatively late first attestation of fría is suggestive of a loan rather than an inherited word.

OIcel. firra 'to deprive, free, save, defend' is attested in Icelandic from the 10th century, in a drápa by Halfreðr Óttarsson. The word must be considered a neoformation since it is a derivative of the adjective firr 'further', comparative form of fjarri 'far'. Truth to tell, the attestation of cognate verbs in West Germanic (OE aferran, OHG firren) could also point in the direction of a common source for the North and West Germanic verbs.

${ }^{16}$ OIcel. kompánn 'companion, fellow' is attested in Icelandic in works from the 13th century. The word is considered a loan from MLG kumpān 's.m.', which in turn is borrowed
} 
An interpretation of this locus of the saga yields the same result with all three models examined in the present paper. In fact, as the reading felogum/ felaugum (SM) is opposed to kumpanum (B), both Finnur Jónsson's and Guðni and Jónas' stemmata (rule 1) suggest that such oppositions are part of two different branches of the tradition, no matter whether $\mathrm{M}$ or $\mathrm{S}$ is considered closer to the original text. Jón Helgason's main rule is rather that the agreement between any two out of three versions is decisive in establishing which variant reading is original.

\section{Discussion and concluding remarks}

In the present article, a text-critical method is used in order to evaluate intrastemmatic variation between loanwords and native synonyms in the manuscript tradition of two sagas of the Icelanders, Egils saga and Gísla saga. Whereas in the case of Egils saga, only one word pair of interest was identified, ${ }^{17}$ in the case of Gísla saga the text, albeit shorter, contains four examples of intrastemmatic loanword/native word alternation. The word pair BUKLARI - SKJQLDR in Egils saga was interpreted as a single substitution made in the text preserved in Möðruvallabók. In analyzing the material from Gísla saga, a comparison of different stemmata was carried out. The result is that in three out of four instances, the three

from OFr. compai(g)n < Lat. companio, companium (IeW, s.v. kompán, kumpán(n), kumpáni; AeW, s.v. kompánn, kumpánn; IOb, s.v. kompáni, kumpáni). The Latin word, whose oldest attestation in from the Pactus legis Salica (ca. 503, Du Cange, s.v. companium), constitutes with all probability a structural calque of a Germanic word similar to Got. gahlaiba 'fellow, companion' and OHG galeipo 's.m.'. The Latin native word for 'fellow, companion' was socius.

OIcel. félagi 'companion, comrade' is attested since the 12th century in Icelandic sources. The word is a neoformation and has no cognates in the Germanic language family outside North Germanic (ODan. faelagh, OSw. falagh, DR 68 runestone (11th c.) filaka) besides OE feólaga, which is a North Germanic loan (OED, s.v. fellow).

${ }^{17}$ Truth to be told, in Egils saga also OIcel. kápa (< Lat. cappa, likely via late OE *cápe $<$ ONFr. cape, cf. OED, s.v. cape) and ólpa (< PGmc *welp-/wlep-, cf. ME wlappen 'to wrap, fold' and NSaam. vuöl'po 'womans coat' < Old West Nordic, ÍOb, s.v. ólpa, olpa and Qvigstad 1893: 351) occur in intrastemmatic variation when compounded with OIcel. loð- 'furred' (cf. OIcel. loðinn 's.m.', Got. liudan 'to grow', OE léodan 'to spring, grow', OS liodan 'to grow' etc., < PGmc *leud-/lud-). However, an intrastemmatic analysis of this word pair yields no conclusive result, as the locus corresponding to IF II: $232^{13}$ is omitted in the $\mathrm{C}$ version (for the A version see Bjarni Einarsson 2001: $141^{3-4}$, B version $(\div \mathrm{W}$, locus preserved in AM 463 4to p. 96 $6^{33-35}$, MS from 1664, see also Schwabe 2015: 8). 
stemmata yield the same result, although the choice between the two variants is based on a different classification of witnesses. In one case, that of BUFFEIT - KINNHESTR, the stemmata by Jón Helgason on one side and Guðni Kolbeinsson and Jónas Kristjánsson on the other give the same result, whereas Finnur Jónsson's stemma cannot determine which of the two readings is to be considered original. Although in the case of the very limited phenomenon analyzed here the results given by the three stemmata are not too divergent, the classification proposed by Guðni Kolbeinsson and Jónas Kristjánsson certainly proves to be the better one. In fact, the phenomenon examined here invariably provides a positive test result for the pentalogue proposed by the two scholars.

Besides the more specifically philological considerations with which we have been dealing so far, some concluding remarks on the nature of the phenomenon under analysis are in order. On a general level, in documenting the phenomenon of coexistence and competition of loanwords and native words the former were all considered equally in the documentation phase, since priority was given to highlighting the contrast between loanwords and native words. Loanwords are a chiefly diachronic phenomenon, whereas on the synchronic plane all lexical material in a given language following its phonological and morphological rules is considered in much the same way, except when specific linguistic knowledge allows for an evaluation of a word's provenance, e.g. when purist attitudes are part of a conscious language policy (Gusmani 1981: 14-15). The situation is different with integral borrowings, i.e. loans which preserve the phonological and in some cases also morphological structure of the source language..$^{18}$ This latter case is often associated with learned use, or at least language use strongly influenced by the prestige of the source language in the recipient language community, in particular with reference to written language. This case is not represented here, nor are integral borrowings in the sagas of the Icelanders very common. ${ }^{19}$

\footnotetext{
${ }^{18}$ This applies chiefly to written language. The problematics concerning integral borrowings in the spoken language, especially on the phonological level, are not addressed since the focus here is on written, rather than spoken, language.

${ }^{19}$ Integral loans from Latin are very common in textual typologies which show a good deal of influence from a learned environment, chiefly religious texts and scientific treatises. Latin integral loans constitute more often than not nonce borrowings, i.e. foreign words which are inserted in the text in order to introduce their native denomination according to the general formula [Latin] pat er [Icelandic]. Other notable cases in which integral loans appear involve names of office, which are often in Latin in official documents, e.g. diplomata (legatus, notarius publicus, officialis, etc.).
} 
In four out of the five cases listed above, the loanwords were adopted into Icelandic in medieval times, and can thus be said to be more or less contemporary with the written media in which they are recorded. In the case of ambatt, however, the situation is different, as the loanword is a borrowing from Celtic into Germanic (Lehmann 1986: s.v. andbahts). A methodological consideration then arises, as to whether cases such as that of ambátt should be treated differently from those of loanwords roughly contemporary with the sources in which they are recorded. The answer seems to be a negative one. ${ }^{20}$ From the overall excerpted data (Tarsi [forthcoming]) it appears that the native lexical strategies underlying the expansion of the lexicon do not differ with respect to loanword chronology. In order to exemplify this general principle, one may consider the typologies of native words corresponding to loanwords whose first attestation in Icelandic is in works composed before and after the twelfth century, i.e. before and after the oldest preserved Icelandic manuscripts. ${ }^{21,22}$ In the former group, which is unexpectedly much smaller than the latter, are words such as ambátt 'slave-woman', biskup 'bishop', djofull 'devil', harri 'lord', klaeði 'clothes', kristinn 'Christian', messa 'mass', ormr 'worm, serpent, dragon', peningr 'coin, money, wealth' all of which are found to alternate with native words, but also other loanwords such as akkeri 'anchor', altari 'altar', eyrir 'ounce, money, property', kaupa 'to buy', karr 'dear' and a number of other loans attested in early skaldic poetry. ${ }^{23}$ The native equivalents of the subgroup ambátt - peningr relate to all the four typologies mentioned above:

\footnotetext{
${ }^{20}$ This consideration applies to the lexicon in general and not to specific lexical uses such as different registers used in a given text. This latter case could be that of Egils saga presented above, where a loanword, whose adoption is with all likelihood contemporary with the manuscript in which a version of the saga is preserved, is present where the original text possibly had the corresponding native lexeme.

${ }^{21}$ The loanwords presented here do not include those which show a hyponymic relationship with a native word.

${ }^{22}$ Such a chronological division is, of course, arbitrary. In fact, there is nothing, in principle, that prevents presumably (or certainly) old loanwords from appearing in works dating from the twelfth century onwards. A representative example is OIcel. kirkja 'church', whose two oldest occurences in poetry and prosa respectively are in Einarr Skúlason's poem Geisli and in the Old Norse translation of the Elucidarius. Both works date from the mid-twelfth century the word may well have been adopted upon the introduction of Christianity (999). Other similar cases include OIcel. paradís 'paradise' (see furthermore the discussion in Tarsi 2016: 89-90, "OIcel. kristinn 12th c." read "11th c.") and OIcel. skrifa 'to write' (Tarsi 2019).

${ }^{23}$ Albeit classified under a single label here, the acquisition of these loanwords spans a lengthy period of time, from the PGmc period until the eleventh century (the conversion to
} 
Tab. 1. A taxonomy of native words corresponding to loanwords attested in works composed before the twelfth century.

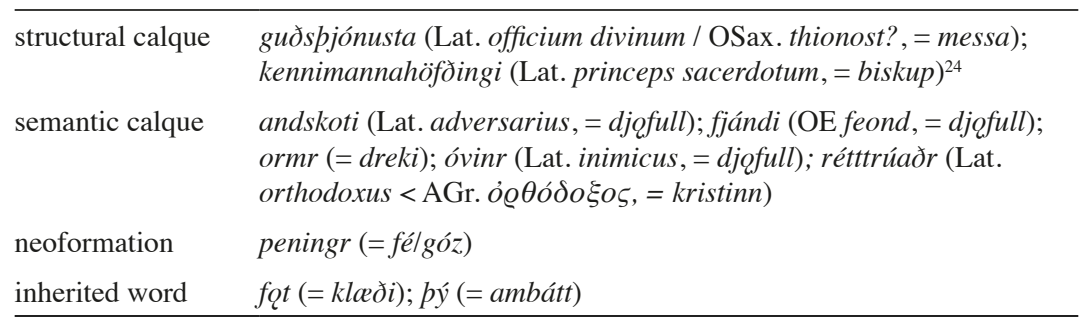

As can be seen, all four strategies are represented also in this small group of loans. It would, of course, be possible to speculate about the productivity of neoformations in this period. Judging from the available data, it seems that the coinage of neoformations flourishes from the twelfth century onwards, whereas before that time a stronger adherence to learned models is found. This result may of course be biased by the extent of early data available and by the textual typology in which they appear, which leads to the prevalence of certain semantic fields over others where stronger adherence to models was called for.

\section{References}

AeW = de Vries, Jan, 1962: Altnordisches etymologisches Wörterbuch. Leiden: Brill.

Bjarni Einarsson (ed.), 2001: Egils saga Skallagrímssonar - Bind I, A-redaktionen. Editiones Arnamagnæanæ, Series A, vol. 19. Copenhagen: C. A. Reitzel.

Chesnutt, Michael, 2005: “Tekstkritiske bemærkninger til C-redaktionen af Egils saga.” Bibliotheca Arnamagnæana XLIV. Opuscula 12. Pp. 228-262.

Chesnutt, Michael (ed.), 2006: Egils saga Skallagrímssonar - Bind III, C-redaktionen. Editiones Arnamagnæanæ, Series A, vol. 21. Copenhagen: C. A. Reitzel.

Christianity). As a result, the borrowing languages from which these words derive are as varied (relatively) as the group of source languages for later loans.

${ }^{24}$ Icel. kennimannahöfðingi is a late-attested native neoformation. It is first found in Oddur Gottskálksson's translation of the New Testament. However, OIcel. hofðingi kennimanna for Lat. princeps sacerdotum is found as early as ca. 1200 (see ONP, s.v. hofðingi). 
Du Cange $=$ Glossarium medice et infima latinitatis. http://ducange.enc.sorbonne. fr. Paris: École nationale des chartes.

EdPCelt. = Matasović, Ranko, 2009: Etymological Dictionary of Proto-Celtic . Leiden: Brill.

Eyvindur Eiríksson, 1977: Miðensk tökuorð í íslensku. Unpublished M.A.-thesis. Reykjavik: Háskóli Íslands.

Falk, Hjalmar, 1914: Altnordisches Waffenkunde. Videnskabs-Selskabets Skrifter II. Historisk-Filologisk Klasse 1914 No. 6. Kristiania: Dybwad.

Finnur Jónsson (ed.), 1886-1888: Egils saga Skallagrímssonar. STUAGNL XVII. Copenhagen: S. L. Møller.

Finnur Jónsson, 1923: Den oldnorske og oldislandske litteraturs historie (vol. II). Copenhagen: Gads Forlag.

Finnur Jónsson (ed.), 1929: Gísla saga Súrssonar ugdiven efter håndskrifterne af Det Kongelige Nordiske Oldskrift-Selskab. Copenhagen: Gyldendal.

Guðni Kolbeinsson and Jónas Kristjánsson, 1979: “Gerðir Gíslasögu.” Gripla III. Pp. 128-162.

Gurevich, Elena (ed.), 2017: “Anonymous Pulur, Skjaldar heiti 1.” In: Gade, Kari Ellen and Edith Marold (eds.), Poetry from Treatises on Poetics. Skaldic Poetry of the Scandinavian Middle Ages 3. Turnhout: Brepols. Pp. 823-824.

Gusmani, Roberto, 1981: Saggi sull'interferenza linguistica (vol. I). Firenze: Le Lettere.

IeW = Alexander Jóhannesson, 1956: Isländisches etymologisches Wörterbuch . Bern: Francke.

ÍF = Íslenzk fornrit, 1933- : Reykjavik: Hið íslenzka bókmenntafélag.

ÍOb = Ásgeir Blöndal Magnússon, 2008: Íslensk orðsifjabók. Reykjavik: Orðabók Háskólans.

Jón Helgason (ed.), 1956: Håndskriftet AM 445c, I, 4to: Brudstykker af VígaGlúms saga og Gísla saga Súrssonar. STUAGNL LXVI. Copenhagen: Jørgensen.

Kjeldsen, Alex Speed (ed.), 2005: “AM 162 A $\delta$ fol (Reykjavík).” Bibliotheca Arnamagnæana XLIV. Opuscula 12. Pp. 71-153.

Konráo Gíslason (ed.), 1849: Tvar sögur af Gísla Súrssyni. Copenhagen: Fornritafélag Norðurlanda í Kaupmannahöfn.

Lethbridge, Emily, 2010: “Gísla saga Súrssonar: Textual variation, editorial constructions and critical interpretations.” In: Quinn, Judy and Emily Lethbridge (eds.), Creating the medieval saga. Odense: University Press of Southern Denmark. Pp. 123-152.

Lethbridge, Emily, 2013: "Dating the Sagas and Gísla saga Súrssonar." In: Mundal, Else (ed.), Dating the Sagas: Reviews and Revisions. Copenhagen: Museum Tusculanum Press. Pp. 77-113.

Lewis/Short = Lewis, Charlton T. and Charles Short (eds.), 1879: A Latin Dictionary. Oxford: Clarendon Press.

Loth, Agnethe (ed.), 1956: Gísla saga Súrssonar. Copenhagen: Munksgaard. 
Loth, Agnethe (ed.), 1960: Membrana regia deperdita. Editiones Arnamagnæane Series A, vol. 5. Copenhagen: Munksgaard.

$M v B=$ van Arkel-de Leeuw van Weenen, Andrea, 1987: Möðruvallabók. Volume one: Index and concordance. Leiden: Brill.

$O E D=$ Oxford English Dictionary. Oxford: Oxford University Press.

OlÍsl. = Eiríkur Rögnvaldsson et al., 1996: Orðstöðulykill Íslendingasagna. Reykjavik: Mál og menning.

ONP $=$ Ordbog over det norrøne prosasprog, http://onp.ku.dk. Copenhagen: Københavns Universitet.

Qvigstad, Just Knud. 1893. Nordische Lehnwörter im Lappischen. Christiania Videnskabs-Selskabs Forhandlinger for 1893 No. 1. Kristiania: Dybwad.

Schwabe, Fabian, 2015: Die Egils saga Skalla-Grímssonar in Cod. Guelf. 9.10 Aug. 4to - Grammatik, Text und Glossar. Ph.D. dissertation. Greifswald: Universität Greifswald.

Skjald. = Finnur Jónsson (ed.), 1912-1915: Den norsk-islandske skjaldedigtning . A I-II. Tekst efter håndskrifterne. B I-II. Rettet tekst. Copenhagen: S. L. Møller.

Tarsi, Matteo, 2016: "On the origin of the oldest borrowed Christian terminology in Icelandic.” Orð og tunga 18. Pp. 85-101.

Tarsi, Matteo, 2019: "Lat. scrībere in Germanic.” NOWELE 72/1. Pp. 42-59.

Tarsi, Matteo, [forthcoming]: Loanwords and native words in Old and Middle Icelandic (12th c.-1550). Ph.D. dissertation. Reykjavik: Háskóli Íslands.

Veturliði Óskarsson, 2003: Middelnedertyske låneord i islandsk diplomsprog frem til år 1500. Bibliotheca Arnamagnæana XLIII. Copenhagen: C. A. Reitzel.

West, Martin L., 1973: Textual Criticism and Editorial Technique. Stuttgart: B. G. Teubner.

Pórður Ingi Guðjónsson, 2010: "Editing the Three Versions of Gísla saga Súrssonar." Translated from Icelandic by Philip Roughton. In: Quinn, Judy \& Emily Lethbridge (eds.), Creating the Medieval Saga: Versions, Variability and Editorial Interpretations of Old Norse Saga Literature. Odense: University Press of Southern Denmark. Pp. 105-121.

\section{Manuscripts}

Den Arnamagnæanske Samling, Copenhagen AM 453 4to

Det Kongelige Bibliotek, Copenhagen NKS 1181 fol.

Herzog August Bibliothek, Wolfenbüttel Cod. Guelf. 9.10. Aug. 4to 
Kungliga biblioteket, Stockholm

Stock. perg. 7 to

Stofnun Árna Magnússonar í íslenskum fræðum, Reykjavik

AM 132 fol.

AM 149 fol.

AM 162a fol.

GKS 1005 fol.

AM 445 c I 4to

AM 462 4to

AM 463 4to

AM 556a 4to

\section{Summary}

In this article, textual variation with reference to loanwords and respective native words is addressed. Examples are taken from two sagas of the Icelanders, Egils saga Skallagrímssonar and Gísla saga Súrssonar. Whereas, in the former, only one significant instance is found, the latter saga provides a handful of cases worth investigating. In the case of Egils saga, the word pair BUKLARI - SKJQLDR is analyzed, and the conclusion drawn is that skjoldr is the original lectio in the passage. With regard to Gísla saga, three different stemmata are compared and reevaluated in light of loanword/native word lexical pairs (АMBÁTT - PÝ, BUFFEIT - KINNHESTR, FRÍA - FIRRA, KOMPÁNN - FÉLAGI). In particular, the pentalogue developed by Guðni Kolbeinsson and Jónas Kristjánsson (1979) is applied to the cases under discussion and its validity confirmed against the stemmata provided by Finnur Jónsson (1929) and Jón Helgason (1956). In the concluding paragraph, it is conjectured that native lexical strategies underlying the expansion of the Icelandic lexicon do not differ with respect to loanword chronology and that the coinage of neoformations develops noticeably from the twelfth century on, whereas before that time a stronger adherence to learned models is identifiable. This latter result may, however, be somewhat distorted, due to the more limited degree of variation in text typologies before the 12th century as opposed to the flourishing of different Icelandic literary genres from the 12th century onwards.

Keywords: Textual variation, loanwords, sagas of the Icelanders, stemmatic method

Matteo Tarsi

University of Iceland

Department of Icelandic and Comparative Cultural Studies

ORCID iD 0000-0001-6548-7874 


\section{Recensioner}

Natalie M. Van Deusen. The Saga of the Sister Saints. The Legend of Martha and Mary Magdalen in Old Norse-Icelandic Translation. Studies and Texts, 214. Toronto: The Pontifical Institute of Mediaeval Studies, 2019. Pp. xiii, 222; 5 ill.

In the Introduction to her book, The Saga of the Sister Saints, Natalie M. Van Deusen sets the stage for the study, edition, and translation of the legend of Martha and Mary Magdalen in Iceland. She offers a brief survey of the development of the legend of Martha and Mary of Bethany from the New Testament accounts to early Biblical exegetical texts and martyrologies, through medieval local cults of Martha and the development of her legend, culminating in the thirteenth century in Jacobus de Voragine's Legenda aurea. Mary of Bethany came to be conflated with Mary Magdalen and evidence of the latter's cult is found in England and Germany in the tenth century, and subsequently in France. The earliest known vita of Mary Magdalen, the vita eremitica, originated in southern Italy in the ninth century, and told of her life in the wilderness. Subsequently the vita apostolica developed, which recounted her proselytization of the Marseilles region. Finally, the two vitae were joined in the composite vita apostolico-eremitica. Mary Magdalen's cult was furthered, especially by the Dominicans, with the inclusion of her legend in the thirteenth-century Legenda aurea and the composition of the early fourteenth-century Book of Miracles of Saint Mary Magdalen.

In the first chapter, "The Sister Saints in the North: The Penitent and the Hostess" (pp. 12-34), Van Deusen surveys church calendars, dedications, inventories, artistic depictions, prayer books, liturgical sources,

Kalinke, Marianne. 2019. Rev. of Natalie M. Van Deusen. The Saga of the Sister Saints. The Legend of Martha and Mary Magdalen in Old Norse-Icelandic Translation.

Scripta Islandica 70: 105-109.

(C) Marianne Kalinke (CC BY)

DOI: https://doi.org/10.33063/diva-400607 
and hagiographic material as evidence of the cult and legend of Martha and Mary Magdalen in medieval Scandinavia. The chapter addresses the similarities and differences in devotion to Martha and Mary Magdalen in Denmark, Norway, Sweden and Finland. Of the two saints, Mary Magdalen seems to have been more popular in Denmark, to judge by the frequent occurrence of her name in prayers. Mary Magdalen is portrayed singly, but also with her sister Martha, in numerous frescos, and she appears to have been especially venerated by the Dominicans. Notably, Mary Magdalen is also the subject of a Danish ballad, in which she is associated with the Samaritan woman at the well. In Norway, Mary Magdalen's feast is celebrated on 22 July, and it is regularly mentioned in Norwegian charters from the beginning of the fourteenth century as well as in letters of indulgence. The saint is portrayed in paintings, sculptures, and textiles in Norway, and celebrated in the ballad "Maria Magdalena", which has been transmitted in eighteen complete transcriptions. To judge by references to feast days of Mary Magdalen in Sweden and Finland, as well as the numerous churches and chapels dedicated to her, devotion to the saint seems to have been more popular there than in Denmark and Norway. Images of Mary Magdalen are found in more than one hundred frescos, altarpieces, sculptures, and textiles. Whereas Martha appears in medieval Swedish prayer books, she is mentioned only in passing and always in connection with Mary Magdalen, prayers to whom are preserved in several prayer books. The legend of Mary Magdalen is found in the Old Swedish Legendary, which derives from the Legenda aurea, but unlike the Latin legendary, the Swedish legendary transmits no independent legend of Martha. A ballad about Mary Magdalen originated in the fifteenth century and survives in transcriptions dating from the end of the eighteenth century.

The survey of devotion to the sister saints in Denmark, Norway, Sweden, and Finland is a fitting backdrop for the investigation in the second chapter (pp. 35-60) of the cult and legends of Martha and Mary Magdalen in Iceland. It contains an exhaustive survey of evidence of their cult, their feast days in calendars, charters, and church inventories. Mary Magdalen is named in testaments, while images of her were owned by several medieval Icelandic churches, and she is represented in a number of manuscript illuminations. Church and monastery inventories reveal that they possessed legends of Mary Magdalen and/or Martha. Mary Magdalen is mentioned in homilies, and references to Martha, who is better represented in Iceland than in other Scandinavian countries, occur in both 
secular and sacred literature. The sister saints appear in both prose and poetry. The outstanding testament to the two saints is the vernacular vita apostolico-eremitica, namely Mortu saga ok Maríu Magðalenu, which derives from a variety of biblical and Latin exegetical sources. Unlike other medieval legends of the sister saints, there is a greater focus in the Icelandic legend on Martha than on Mary, whose apocryphal legend is relatively reduced. Mortu saga ok Maríu Magðalenu commences with an introduction to Martha, with a focus on her virtues, her celibacy, her hospitality and domestic abilities. Van Deusen notes that as a representative of the vita activa, Martha was an ideal model for Icelandic women in the domestic sphere.

Chapter 3 (pp. 61-90) is devoted to a discussion of the manuscripts and transmission of Mortu saga ok Maríu Magðalenu, its sources, authorship, and provenance. Van Deusen points out that only four Latin composite legends of Mary Magdalen and Martha are extant, but that none of these is similar to the blend of content and sources in the Icelandic compilation. She suggests that the composite legend of the sister saints was written in Iceland around 1350, and that its author may have been Arngrímr Brandsson, abbot of the Benedictine monastery of Pingeyrar. She argues that the legend's style, use of sources, and content are similar to those of other prose works attributed to Arngrímr, in which he employed alliteration, connective formulae, and antitheses, as well as rhetorical questions and phrases. The primary source of Mortu saga ok Maríu Magðalenu was Vincent of Beauvais's Speculum historiale, one of Arngrímr's sources in his writings, but also various other Latin sources, such as Peter Comestor's Historia scholastica.

The focus of chapter 4 (pp. 91-112) is on women preachers and the question of genre. Van Deusen points out that Mortu saga ok Maríu Magðalenu has traditionally been classified with the heilagra meyja sögur, the legends of virgin martyrs, but observes that the saga of the sister saints differs substantially from these in content. She argues that the focus of the legend of Martha and Mary is on their apostolic mission and notes that in a scene after the Resurrection Mary is designated as "postoli postolanna", a direct translation of the Latin apostolorum apostola, a common epithet for Mary Magdalen during the Middle Ages. The Icelandic saga recounts Mary's missionary efforts and preaching in Provence - the Latin loan prédikaði occurs - and she is compared to the apostle Peter. Similarly, there is a focus on Martha's preaching ministry in the legend. Van Deusen therefore suggests that the legend of Martha and 
Mary might more appropriately be classified with the postola sögur rather than the heilagra meyja sögur. Van Deusen notes, however, that neither the law codes nor other relevant texts address the issue of preaching by women. Whereas there is some confirmation of women teaching within a formal ecclesiastical context in Iceland - in one instance a woman teaches a young boy to read the psalter - the sole evidence of women preaching is found in Mortu saga ok Maríu Magðalenu.

Natalie Van Deusen's study of the saga of the sister saints concludes with an edition of Mortu saga ok Maríu Magðalenu (pp. 116-203), with a critical apparatus of variant readings. The English translation on facing pages has notes indicating Latin sources. On the whole, the edition is exemplary, as is the English translation, though the latter occasionally replicates what seems rather awkward syntax that Van Deusen ascribes to the Latin source. One of the idiosyncrasies of the legend is that words spoken by Jesus are usually followed by an exgetical restatement introduced by the clause, "sem hann segði", which Van Deusen translates with "as though he said". In her note on the translation, Van Deusen writes that her goal is readability, and that colloquialisms and idiomatic phrases are rendered into their best English equivalents. That is indeed the case, but occasionally the tone seems not quite right, for example, when Jesus appears to his disciples and says Heilar sé pér, which is rendered with the rather abrupt "Greetings" (pp. 150-51). Similarly, at the death of Mary Magdalen, her body rests in the chapel for seven days and everyone noticed ilm mikinn, translated as "a powerful smell" (pp. 172-73). In this context, "smell" suggests a decomposing body, but the ilm mikinn refers here to the odor of sanctity, and "fragrance" would have been more appropriate. Such small quibbles aside, Van Deusen has produced a reliable translation of a rather difficult text.

Van Deusen argues convincingly that Mortu saga ok Maríu Magðalenu was composed around 1350, most likely by Arngrímr Brandsson, abbot of the Benedictine monastery of Pingeyrar. Therefore, I think it odd that her edition of the saga is normalized to a spelling standard from circa 1200 (as found in the Íslenzk fornrit editions of the Íslendinga sögur), especially since the manuscripts on which the text is based, Holm Perg. 2 fol. and AM 235 fol., are dated to the early fifteenth century. In other words, the orthographic normalization suggests a text some two centuries older than it is. A fourteenth-century orthographic standard might have been more appropriate, like that adopted by Guðrún Ása Grímsdóttir in her edition of Sögupáttr af Jóni Halldórssyni biskupi (in Biskupa sögur 
Rev. of Natalie M. Van Deusen. The Saga of the Sister Saints 109

III, 1998), the account about Arngrímr's contemporary and friend, Bishop Jón Halldórsson.

Natalie Van Deusen's The Saga of the Sister Saints. The Legend of Martha and Mary Magdalen in Old Norse-Icelandic Translation is exemplary. The introductory study situates the Icelandic legend in the broader context of Latin hagiography and the cult of the sister saints in mainland Europe and Scandinavia. The analysis of the distinctive cult and legend in Iceland provides a fitting basis for the edition and translation of the vernacular vita apostolica-eremitica.

Marianne Kalinke

University of Illinois at Urbana-Champaign

kalinke@illinois.edu 

Anders Hultgård. Midgård brinner. Ragnarök $i$ religionshistorisk belysning. Acta Academiae Regiae Gustavi Adolphi CXLVI. 2017. Uppsala. ${ }^{1}$

Myten om Ragnarök berättades under vikingatiden i Norden och blev senare under medeltiden nedtecknad på fornvästnordiskt språk i poetiska verk och prosatexter på Island. Denna eskatologiska myt handlar om världens och gudarnas undergång, men också om jordens förnyelse och återuppståndelse. Frågor som rör mytens egenart, förändring och ursprung har diskuterats intensivt $\mathrm{i}$ den tidigare forskningen. Eftersom många religioner och kulturområden med skiftande språk dragits in i den diskussionen ställs höga krav på den forskare som på allvar ämnar ge sig in i debatten. En forskare som kan motsvara dessa krav är religionshistorikern Anders Hultgård. Han har arbetat med dessa frågor under decennier och nu föreligger resultatet i ett spränglärt och massivt verk Midgård brinner. Ragnarök i religionshistorisk belysning, som getts ut av Kungl. Gustav Adolfs Akademien för svensk folkkultur. Med orden "Midgård brinner" (brinnit mittilagart) sammanfattar den forntyska dikten Muspilli världens undergång. Dessa ord som uppträder i bokens titel skulle också kunna sammanfatta myten om Ragnarök.

Boken omfattar sju kapitel, samt förkortningar och en bibliografi. I inledningskapitlet diskuteras begreppet Ragnarök. De flesta är överens om att förleden ragna- är en genitiv plural av ordet regin 'de rådande, gudarna'. Den andra leden som föreligger i två former - rq̨k och $r \phi k(k) r-$ är däremot mer omdiskuterad. I Snorres Edda möter vi sammansättningen $\operatorname{ragnar} \phi k(k) r$, vilken vanligtvis översätts 'gudaskymning'. I poesin möter vi däremot formen ragnarq̨, som enligt gängse tolkning betyder 'gudarnas öde'. Hultgård har en annan uppfattning och menar att efterleden $r q k$, $(r \phi k)$ ska tolkas 'väsentliga mytiska tilldragelser'. I de äldsta bevarade fornvästnordiska handskrifterna (ca 1150-1200) och i

\footnotetext{
${ }^{1}$ Recensionen är tidigare publicerad i Chaos: Skandinavisk tidsskrift for religionshistoriske studier (68) 2017 vol. II, 209-213.
}

Sundqvist, Olof. 2019.

Rec. av Anders Hultgård. Midgård brinner. Ragnarök i religionshistorisk belysning. Scripta Islandica 70: 111-117.

(C) Olof Sundqvist (CC BY)

DOI: https://doi.org/10.33063/diva-400608 
den poetiska traditionen har nämligen ordet rq̨k den betydelsen. Sammansättningen ska således tolkas 'väsentliga mytiska tilldragelser som rör gudarna'. I inledningskapitlet får vi även en forskningshistorisk skiss, som framförallt tar fasta på den version av ragnaröksmyten som föreligger i eddadikten Vǫluspá, dvs. huvudkällan till myten. Man diskuterade tidigt om denna version av myten tillkommit under kristen påverkan eller om den var baserad på en redan existerande inhemsk tradition. Tre tolkningslinjer kan skönjas: (1) Ragnaröksmyten är en sammansmältning av skilda mytmotiv med ursprung $i$ olika religioner. Den mest framträdande företrädaren för den linjen var Axel Olrik som såg myten som en mosaik, där olikfärgade stenar representerade olika mytmotiv med ursprung i iranska, keltiska och kristna traditioner. Även Richard Reitzenstein såg likheter mellan den nordiska och iranska myten. Han hävdade att en ursprunglig iransk myt om världens undergång hade upptagits och omvandlats av manikéer, och via manikeismen spred den sig till Gallien alternativt Ryssland, för att därifrån påverka nordborna. (2) Ragnaröksmyten som ett uttryck för indoeuropeisk mytologi. En tidig företrädare för denna tolkning var Victor Rydberg, som såg slående likheter mellan den nordiska och iranska eskatologin. Stig Wikander och Georges Dumézil antog att dessa myttraditioner byggde på ett gemensamt indoeuropeiskt arv då de även fann likheter mellan Ragnarök och den stora striden som omtalas i det indiska eposet Mahābhārata. (3) Ragnaröksmyten har tillkommit genom ett starkt inflytande från kristen eskatologi. Vissa forskare, t.ex. Sophus Bugge och Jan de Vries, menar att det aldrig fanns en sammanhängande ragnaröksmyt förrän det att kristendomen nådde Norden. Myten uppstod då den gamla religionen gick mot sin upplösning, vilket utlöste en oro som bidrog till mytens utformning. Det var dock främst den kristna eskatologin som gav stoff till ragnaröksmyten även om vissa enskilda mytmotiv kan ha haft en inhemsk bakgrund. Några forskare, t.ex. A.C. Bang, menade att de judisk-kristna Sibyllinska Oraklen kan ha utgjort en förebild för Vǫluspá och dess apokalyptiska myt. Anders Hultgård ställer sig tveksam till den tredje tolkningslinjen, som ser Vęluspá som en halvt kristen dikt. Dikten omfattar enligt hans mening en förkristen föreställningsvärld. Han ställer sig också tveksam till de forskare som hävdar att Ragnarök och motivet med fimbulvinter ska ses som en reflex av en naturkatastrof, som utlöstes av ett antal väldiga vulkanutbrott åren 536 och 540 e.Kr. Motivet med fimbulvintern går säkert tillbaka på en äldre tradition, vilket förekomsten av samma mytmotiv i iransk tradition tyder på. I slutet av kapitlet presenteras syfte 
och metod. Genom ett komparativt tillvägagångssätt ämnar Hultgård undersöka huruvida myten har en sådan särart att den inte kan förklaras utifrån en kristen föreställningsvärld utan måste ses som ett uttryck för en äldre inhemsk tradition. I kapitel II studeras sedan ragnaröksmytens historiska och sociala kontext. Enligt Hultgård berättades myten i hallar och kultbyggnader på stormannagårdar under vikingatiden. I dessa elitära miljöer hade myten en central betydelse för krigarfursten och hans följe. Enhärjarna i Valhall motsvarade egentligen krigarna i de reella hallarna. I den vikingatida hallen vid Garnisonen i Birka, t.ex., finns arkeologiska spår av ett sådant följesväsen. Mot bakgrund av ramen till och talaren i Voluspá behandlar Hultgård även de sierskor som benämndes vǫlur (vqlva sg.) i de norröna källorna. De har där en betydelsefull roll och tycks ha varit högt uppskattade i det vikingatida samhället, också i mer elitära kretsar. Även klassiska källor vittnar om den höga prestige sierskor åtnjöt bland germanerna.

Kapitel III omfattar en detaljerad genomgång av ragnarökstraditionen i de skriftliga källorna, samt en diskussion kring de tolkningar som förekommit i anslutning till dem. Hultgårds metod utgår från en noggrann textanalys, där syftet är att så långt som möjligt se vad texterna säger oss. I de översättningar som presenteras har Hultgård undvikit att återge originalets form med stavrim och versmått. Det skulle framtvinga friare översättningar, vilket också skulle innebära en förflyttning bort från textens grundmening. Kapitlet inleds med en analys av ragnaröksmytens huvudkälla, Vǫluspá str. 38-66. Hultgård har här valt att översätta varje vittnesmål av den, var för sig, vilket innebär att Codex Regius (R), Hauksbók (H) och manuskripten till Snorres $E d d a(\mathrm{~S})$ presenteras i tre separata spalter. Därefter görs en noggrann analys av varje enskild strof där författaren även diskuterar de ställen där manuskripten skiljer sig åt. Av de övriga eddadikterna som återger myten om världens undergång och förnyelse får Vafprúðnismál (str. 17-18, 38-39 och 44-55) ett stort utrymme, medan de andra eddadikterna behandlas mer kortfattat. De tidigaste daterbara beläggen för myten finns i två skaldedikter från ca 950, nämligen Eiríksmál och Hákonarmál. Även de analyseras på ett grundligt sätt. Kenningar och anspelningar på ragnaröksmyten i andra skaldedikter omtalas mer översiktligt. Därefter behandlas mytens uppträdande i den fornisländska prosan, där Snorres beskrivning i Gylfaginning 51-53 har en särställning. I översättningen av Snorres text håller Hultgård isär den version av myten som möter oss i de mer samstämmiga manuskripten R-W-T och den som finns i Uppsalaeddan (U). Saxos skildring av Bråvallaslaget på latin har 
ibland betraktats som en reflexion av Ragnarök, men Hultgård avvisar den tolkningen. Hultgård konkluderar att de versioner av myten som kommer fram i de poetiska texterna ska prioriteras. Trots sin allusiva karaktär ger de den mest tillförlitliga bilden av den gamla myten.

I kapitel IV diskuteras de bilder som förmodats skildra ragnaröksmyten. Kapitlet inleds med en metoddiskussion kring de problem som forskaren möter vid bildtolkning. Vems bildtolkning söker vi? Beställaren av bilden? Konstnären som skapade bilden eller de människor som iakttog den? Hultgård påpekar att människor i olika tidsepoker har lagt in olika meningar i bilderna och därför har deras betydelse förändrats. Ett fyrfota djur kan av vissa ha satts samman med Ragnarök, medan andra associerade det till den kristna eskatologiska myten. Bildens mening och betydelse ligger i betraktarens öga och kan ha skiftat i olika kontexter. Hultgård inleder sedan diskussionen med de vikingatida bildstenarna på Gotland, bland annat ryttaren och kvinnan på stenen från Tjängvide I (SHM 4171). Han menar att kvinnan med dryckeshornet inte alls behöver återge en valkyrja i Valhall, utan snarare ska knytas till ett mer allmänt föreställningskomplex som handlar om hur en mytisk kvinna möter människan efter döden. Detta motiv förekommer i både iranska och grekiska traditioner. Därmed faller den bilden som en källa till ragnaröksmyten. Möjligtvis kan man se något av motiven på det gotländska Ardre-monumentet som föreställande stridande och drickande enhärjar i väntan på Ragnarök. Av runstenarnas bildmotiv är det de som finns på Ledbergstenen, Östergötland, som är mest intressanta i sammanhanget. Bilderna på A- och B-sidan kan där, enligt Hultgård, alludera på den stora slutstriden vid Ragnarök, trots korset på C-sidan: "Torgöt kan ha hyst förhoppningen att efter sin död som en av enhärjarna en gång få kämpa på den goda sidan mot de makter som vill förgöra världen" (s. 183). Även de vikingatida stenskulpturerna från England diskuteras, t.ex. Gosforthkorset. Hultgård är generellt skeptisk till att föra dem samman med ragnaröksmotivet. Några vikingatida bildvävnader behandlas också grundligt, bland annat Överhogdalsbonaden från Härjedalen. Men även där är det enligt Hultgård svårt att på ett övertygande sätt föra samman de scener som finns på den med ragnaröksmyten.

I kapitel V diskuteras ragnaröksmytens vidare religionshistoriska sammanhang. Myten traderades i ett samhälle där kristendomen fått ett visst inflytande. Därmed ställdes myten in i ett vidare sammanhang som kan ha beröringspunkter med en rad religiösa traditioner, judendom och islam, iransk, grekisk och romersk religion, men också keltisk, indisk, slavisk 
och baltisk religion. I kapitlet visar Hultgård prov på vida och djupa kunskaper om dessa religioner och deras eskatologiska traditioner, där han även återger de flesta av deras urkunder och källor på originalspråk, t.ex. latin, grekiska, hebreiska, avestiska (zand), medelpersiska och forniriska. Avsikten med kapitel VI är att försöka förstå ragnaröksmyten ur ljuset av de eskatologiska föreställningar som förekommer i ovan nämnda religioner. Genom jämförelser med dem, där likheter och olikheter diskuteras, kan man få fram den nordiska mytens egenart. Kapitlet är tematiskt disponerat och utgår från den uppbyggnad som myten har i Voluspá och Snorres Edda:

- Allehanda tecken och omvälvningar som förebådar världens slut.

- Skrämmande odjur och demoniska motståndare.

- Den stora slutstriden.

- Världen går under.

- En ny värld uppstår.

Tecken som förebådar världens slut beskrivs utförligt i judisk-kristna och indoiranska traditioner, men är mindre framträdande i Skandinavien. Motivet med fjättrandet och lössläppandet av ett demoniskt väsen i den yttersta tiden knyter tydligt samman de iranska och skandinaviska traditionerna. Så förhåller det sig även med slutstriden, där ont ställs mot gott. Hultgård menar att det här måste föreligga gemensamma rötter mellan dessa traditioner. I judisk-kristna traditioner har konfrontationen färre krigiska uttryck. Motivet med världsbranden finns i andra religioner, men det är endast i den skandinaviska och de indoiranska traditionerna elden får förödande konsekvenser och leder till undergång. I iranska och grekiska traditioner har världsbranden dessutom en renande och återställande funktion. Tanken om världens och naturens pånyttfödelse finns även i Norden. I judisk-kristen och senantik tradition förekommer visserligen elden, men den har mindre verkan och betydelse där.

I det sjunde och sista kapitlet dryftas åter de övergripande frågorna som rör mytens särprägel och ursprung, men också förändringar som skett under traderingen. För att få fram mytens egenart måste den främst jämföras med den tradition som av historiska skäl ligger närmast den, nämligen den kristna. Här föreligger flera väsentliga skillnader. Den skandinaviska föreställningen om att naturen förnyas efter världens undergång saknas i den kristna eskatologin. Inte heller det krigiska inslaget som finns vid Ragnaröks slutstrid förekommer i den kristna mytologin. Där beskrivs uppgörelsen mellan gott och ont som ett domsförfarande. Före- 
ställningen om ett människopar som överlever den hårda vintern på en skyddad plats, saknas också i de kristna traditionerna. Ragnaröksmytens egenart framträder således tydligt då man jämför den med kristendomens eskatologi.

Den vikingatida traditionen om världens slut kom att leva kvar efter religionsskiftet och gav kristendomen nya impulser. Visserligen representerade Ragnarök och Domedagen två olika eskatologier, men här fanns flera beröringspunkter. Ofta säger man att det var kristendomen som kom att ge nytt stoff till den skandinaviska eskatologin, men helt klart har även ragnaröksmyten påverkat den tidiga kristendomen. Ett exempel på detta är runinskriften på den korsprydda Skarpåkerstenen (Sö 154) från Södermanland (1000-tal): "Gunnar reste denna sten efter sin son Lydbjörn. Jorden skall rämna och den höga himlen." Enligt Hultgård finns här möjligen en anspelning på Ragnarök. Budskapet är: ’Ingen bättre son än Lydbjörn kommer att finnas innan världen går under" (s. 392). Hultgård visar på flera källtexter där kristna företrädare anpassat sitt budskap till den skandinaviska mytologin, t.ex. då Leviatan kallas Miðgarðarormr i Niðrstigningarsaga.

Hultgård avslutar sitt verk med att diskutera ragnaröksmytens ursprung. I den inhemska skriftliga källorna kan vi följa den bak till ca 950. Men förmodligen är den betydligt äldre än så. Jämförelser med eskatologiska traditioner från Iran talar för det. Framställningar av det kosmiska trädet är slående lika i de iranska och nordiska traditionerna, där de utgör symboler för tid och rum. Även motivet med fimbulvintern och människosläktets överlevnad på en skyddad plats (Hoddmimers skog) har en direkt parallell i den iranska myten om det människopar som undkom den stränga och långvariga vintern i guden Yimas underjordiska boning, vara'n. Ulvens (ulvarnas) angrepp på himlakropparna vid Ragnarök har en direkt överensstämmelse med draken Gozihrs kamp mot solen och månen, som omtalas i Bundahišn. En motsvarighet till slutstridens mytiska krigare, enhärjarna, finner vi också i iransk religion. Där finns en grupp krigare, som ska ledas av "den sista fullkomnaren", Saošyant'en, i slutstriden mot ondskans makter (se Yašt 19). Även temat med jordens renande och naturens pånyttfödelse finns i båda religionernas traditioner. Hultgård konkluderar sin studie med att konstatera att ragnaröksmyten har ett inhemskt ursprung. Jämförelsen med den kristna eskatologin vittnar om mytens särprägel. Vissa detaljer kan härstamma från den kristna tankevärlden, men de har ingenting med mytens kärna att göra. Ragnaröksmyten liknar däremot på ett slående sätt den iranska eskatologin. Det 
handlar dock inte om ett överförande av mytmotiv från Iran till Skandinavien. Vi står snarare "inför två eskatologiska föreställningskomplex som utgör oberoende utvecklingar av en arkaisk indoeuropeisk myt om världens undergång och förnyelse" (s. 416).

Det finns inget tvivel om att Hultgårds omfattande och djuplodade arbete över Ragnarök kommer att utgöra ett standardverk för flera decennier framöver. Bokens disposition är noggrant genomtänkt, språket och resonemangen är kristallklara, och här finns så vitt jag kan se ytterst få korrekturfel. Rent metodiskt utgör Hultgårds arbete ett gott exempel på och mönster för ett meningsfullt komparativt tillvägagångssätt. Visst finns det enskilda ståndpunkter där man kan ha en annan uppfattning, men i de flesta fall är författarens konklusioner övertygande. Boken omfattar också många fina bilder av runstenar och forntida monument, som bidragit till det positiva helhetsintrycket. Flera av dessa foton är tagna av författarens hustru Ulla-Maj Hultgård och de håller hög klass. Kanske hade man önskat att detta innehållsrika verk hade haft ett index, å andra sidan kan den omfattande innehållsförteckningen fylla en liknande funktion.

Att ingående studera ragnaröksmyten ur ett komparativt perspektiv kräver, som underströks ovan, mycket omfattande religionshistoriska kunskaper och djup kännedom om ett antal forntida språk och texter. Det är därför få forskare som kan axla ett sådant arbete. Efter att ha läst Anders Hultgårds bok känner man sig frestad att travestera författarens tolkning av Skarpåkerstenen: Ingen bättre studie över Ragnarök kommer att finnas innan världen går under.

Olof Sundqvist

Stockholms universitet

Institutionen för etnologi, religionshistoria och genusvetenskap

ORCID iD 0000-0002-4304-9782 



\title{
Berättelse om verksamheten under 2018
}

\author{
Agneta Ney \& MARCO BiAnCHI
}

Isländska sällskapets styrelse hade under år 2018 följande sammansättning:

ordförande: Agneta Ney

vice ordförande: Veturliði Óskarsson (redaktör för Scripta Islandica)

sekreterare: Marco Bianchi

skattmästare: Jan Axelson

vice sekreterare: Alexandra Petrulevich

ledamöter: Phil Beier (från 23 maj), Simon Karlin Björk, Jessica Holmlund, Tommy Kuusela, Lasse Mårtensson (redaktör för Scripta Islandica) och Ingela Vretblad (fram till 23 maj).

Vid årets utgång var 39 personer och institutioner ständiga medlemmar eller hedersmedlemmar i sällskapet. Antalet medlemmar/prenumeranter på sällskapets e-postlista uppgick till 128 personer. Scripta Islandica prenumererades av 44 personer och institutioner.

Den sextionionde årgången av Scripta Islandica utkom som fulltextpublikation i Digitala vetenskapliga arkivet (DiVA) i slutet av 2018. Följande sakkunniggranskade uppsatser ingår i volymen: Klas af Edholm, "Att rista blodörn: Blodörnsriten sedd som offer och ritualiserad våldspraktik i samband med maktskiften i fornnordisk tradition"; Jan Ragnar Hagland, "Litt om kvinnekroppen i norrøn leksikografisk samanheng"; Luke John Murphy, "Paganism at Home: Pre-Christian Private Praxis and Household Religion in the Iron-Age North"; Ludger Zeevaert, "Eine deutsche Zusammenfassung von Njáls saga im Manuskript Rostock Mss. philol. 78/2"; Heimir Pálsson, "Nordens latin"; Sigurður Gylfi Magnússon, "What Takes Place, When Nothing Happens? The importance of late modern manuscript culture". Årgången innehåller följande recensioner: Pernille Hermann, rec. av "Echoes of Valhalla. The Afterlife of the Eddas and Sagas" av Jón Karl Helgason; Mikael Males, rec. av "Skaldic Poetry of the Scandinavian Middle Ages, 3: Poetry from Treatises on Poetics", 
utg. av Kari Ellen Gade med Edith Marold; Alexandra Petrulevich, rec. av "Studies in the transmission and reception of Old Norse literature. The Hyperborean muse in European culture", red. av Judy Quinn \& Adele Cipolla; Olof Sundqvist, rec. av "How Thor Lost his Thunder. The Changing Faces of an Old Norse God" av Declan Taggart; Vésteinn Ólason, rec. av "Poetry in fornaldarsögur. Part 1 and 2", utg. Margaret Clunies Ross.

Vid årsmötet den 23 maj höll professor emeritus Anders Hultgård ett föredrag över ämnet "Midgård brinner: Ragnarök i religionshistorisk belysning". Den 15 september anordnade Isländska sällskapet och Ortnamnssällskapet i Uppsala en gemensam höstutflykt under rubriken "Eddan i Uppland". Utflyktsmålen var runstenarna i Altuna, Drävle och Stora Ramsjö samt ortnamn på vägen. 40 personer, varav 20 studenter, deltog i utflykten. Den 11 oktober genomförde Isländska ambassaden tillsammans med Institutionen för nordiska språk och Isländska sällskapet ett heldagsseminarium med anledning av Islands hundraårsfirande som suverän stat. Samma kväll höll sällskapet ett extra höstmöte med Már Jónsson, professor i historia vid Islands universitet, som föreläsare. Hans föredrag hade titeln "En islandsk drømmedagbok fra 1794". Vid höstmötet den 14 november gästades sällskapet av Gísli Sigurðsson, professor vid Stofnun Árna Magnússonar í íslenskum fræðum i Reykjavík, som talade över ämnet "Snorri's Edda: A mythological terminology about the sky as we see it with our own eyes". Som avslutning på en händelserik hösttermin i Eddans tecken anordnade Isländska sällskapet den 11 december "Speed date med den poetiska Eddan" med ett tiotal kortföredrag om den poetiska Eddan. Arrangemanget genomfördes i samarbete med Institutionen för nordiska språk och med ekonomiskt stöd från Kungl. Gustav Adolfs Akademien för svensk folkkultur (Gun Widmarks fond).

Uppsala den 16 maj 2019

Agneta Ney och Marco Bianchi 


\section{Författarna i denna årgång}

Lise Gjedss $\varnothing$ Bertelsen, Ph.D., senast verksam som Marie Curie Research Fellow vid Uppsala universitet, Institutionen för arkeologi och antik historia, ORCID iD 0000-0002-5719-5481.

Anders Hultgård, professor emeritus, Uppsala universitet, Teologiska institutionen, anders.hultgard@teol.uu.se.

Marianne Kalinke, Professor Emerita, University of Illinois at UrbanaChampaign,kalinke@illinois.edu.

Ada Kan, tidigare forskare vid Institutionen för internationell ekonomi och politik vid Vetenskapsakademien i Moskva samt bibliotekarie vid Uppsala universitetsbibliotek, ada.kan@ownit.ru.

Lars Lönnroth, professor emeritus, Göteborgs universitet, Institutionen för litteratur, idéhistoria och religion, ORCID iD 0000-0001-5604-529X.

Andras Mortensen, Associate Professor, University of the Faroe Islands, Faculty of History and Social Sciences, ORCID iD 0000-0002-58195192.

Agneta Ney, docent i historia vid Uppsala universitet, agneta.ney@telia.com. Guðmundur Ólafsson, Senior Researcher, National Museum of Iceland, ORCID iD 0000-0001-6284-3773.

Hubert Seelow, Professor emeritus, Friedrich-Alexander-Universität Erlangen-Nürnberg (FAU), Department Germanistik und Komparatistik, hubert.seelow@gmx.net.

Olof Sundqvist, professor, Stockholms universitet, Institutionen för etnologi, religionshistoria och genusvetenskap, ORCID iD 0000-00024304-9782.

Matteo Tarsi, Ph.D. Student, University of Iceland, Department of Icelandic and Comparative Cultural Studies, ORCID iD 0000-0001-6548-7874. 



\section{Scripta Islandica ISLÄNDSKA SÄLLSKAPETS ÅRSBOK}

ÅRGÅNG 1 · 1950: Einar Ól. Sveinsson, Njáls saga.

ÅRGÅNG 2 - 1951: Chr. Matras, Det færøske skriftsprog af 1846.-Gösta Franzén, Isländska studier i Förenta staterna.

ÅRGÅNG 3 - 1952: Jón Að̃alsteinn Jónsson, Biskop Jón Arason.-Stefan Einarsson, Halldór Kiljan Laxness.

ÅRGÅNG 4 - 1953: Alexander Jóhannesson, Om det isländske sprog.-Anna Z. Osterman, En studie över landskapet i Voluspá.-Sven B. F. Jansson, Snorre. ÅRGÅNG 5 - 1954: Sigurður Nordal, Tid och kalvskinn.-Gun Nilsson, Den isländska litteraturen i stormaktstidens Sverige.

ÅRGÅNG 6 · 1955: Davíd Stefánsson, Prologus till »Den gyllene porten».Jakob Benediktsson, Det islandske ordbogsarbejde ved Islands universitet.Rolf Nordenstreng, Vọlundarkviða v. 2.-Ivar Modéer, Över hed och sand till Bæjarstaðarskogur.

ÅRGÅNG 7 · 1956: Einar Ól. Sveinsson, Läs-och skrivkunnighet på Island under fristatstiden.-Fr. le Sage de Fontenay, Jonas Hallgrimssons lyrik.

ÅRGÅNG 8 - 1917: Porgils Gjallandi (Jón Stefánsson), Hemlängtan._Gösta Holm, I fågelberg och valfjära. Glimtar från Färöarna.-Ivar Modéer, Ur det isländska allmogespråkets skattkammare.

ÅRGÅNG 9 - 1958: K.-H. Dahlstedt, Isländsk dialektgeografi. Några synpunkter.-Peter Hallberg, Kormáks saga.

ÅRGÅNG 10 • 1959: Ivar Modéer, Isländska sällskapet 1949-1959.-Sigurður Nordal, The Historical Element in the Icelandic Family Sagas._Ivar Modéer, Johannes S. Kjarval.

ÅRGÅNG 11 - 1960: Sigurd Fries, Ivar Modéer 3.11.1904-31.1.1960.Steingrímur J. Porsteinsson, Matthías Jochumsson och Einar Benediktsson.Ingegerd Fries, Genom Ódáđahraun och Vonarskarð-färder under tusen år.

ÅRGÅNG 12 · 1961: Einar Ól. Sveinsson, Njáls saga.

ÅRGÅNG 13 - 1962: Halldór Halldórsson, Kring språkliga nybildningar i nutida isländska.-Karl-Hampus Dahlstedt, Gudruns sorg. Stilstudier över ett eddamotiv.-Tor Hultman, Rec. av Jacobsen, M. A.-Matras, Chr., Föroyskdonsk orðabók. Færøsk-dansk ordbog. 
ÅRGÅNG 14 · 1963: Peter Hallberg, Laxness som dramatiker.-Roland Otterbjörk, Moderna isländska förnamn.-Einar Ól. Sveinsson, Från Mýrdalur. ÅRGÅNG 15 · 1964: Lars Lönnroth, Tesen om de två kulturerna. Kritiska studier i den isländska sagaskrivningens sociala förutsättningar. - Valter Jansson, Bortgångna hedersledamöter.

ÅRGÅNG 16 · 1965: Tryggve Sköld, Isländska väderstreck.

ÅRGÅNG 17 · 1966: Gun Widmark, Om nordisk replikkonst i och utanför den isländska sagan. - Bo Almqvist, Den fulaste foten. Folkligt och litterärt i en Snorri-anekdot.

ÅRGÅNG 18 · 1967: Ole Widding, Jónsbóks to ikke-interpolerede håndskrifter. Et bidrag til den isländske lovbogs historie.-Steingrímur J. Porsteinsson, Jóhann Sigurjónsson och Fjalla-Eyvindur.

ÅRGÅNG 19 - 1968: Einar Ól. Sveinsson, Eyrbyggja sagas kilder.-Svávar Sigmundsson, Ortnamnsforskning på Island.-Lennart Elmevik, Glömskans häger. Till tolkningen av en Hávamálstrof._Berättelsen om Audun, översatt av Björn Collinder.

ÅRGÅNG 20 • 1969: Sveinn Höskuldsson, Skaldekongressen på Parnassen - en isländsk studentpjäs._Evert Salberger, Cesurer i Atlakviða.

ÅRGÅNG 21 · 1970: Davíð Erlingsson, Etiken i Hrafnkels saga Freysgoða._Bo Almqvist, Isländska ordspråk och talesätt.

ÅRGÅNG 22 · 1971: Valter Jansson, Jöran Sahlgren. Minnesord.-Lennart Elmevik, Ett eddaställe och några svenska dialektord.-Bjarne Beckman, Hur gammal är Hervararsagans svenska kungakrönika?-Baldur Jónsson, Några anmärkningar till Blöndals ordbok. - Evert Salberger, Vel glýioð eller velglýioð. En textdetalj i Voluspá 35.-Anna Mörner, Isafjord.

ÅRGÅNG 23 - 1972: Bo Ralph, Jon Hreggviðsson-en sagagestalt i en modern isländsk roman._Staffan Hellberg, Slaget vid Nesjar och »Sven jarl Håkonsson».-Thorsten Carlsson, Norrön legendforskning-en kort presentation.

ÅRGÅNG 24 · 1973: Peter Hallberg, Njáls saga-en medeltida moralitet?Evert Salberger, Elfaraskáld —ett tillnamn i Njáls saga._Richard L. Harris, The Deaths of Grettir and Grendel: A New Parallel.-Peter A. Jorgensen, Grendel, Grettir, and Two Skaldic Stanzas.

ÅRGÅNG 25 · 1974: Valter Jansson, Isländska sällskapet 25 år.-Ove Moberg, Bröderna Weibull och den isländska traditionen.-Evert Salberger, Heill pú farir! Ett textproblem i Vafprúðnismál 4._Bjarne Beckman, Mysing.-Hreinn Steingrímsson, »Að kveða rímur».-Lennart Elmevik, Två eddaställen och en västnordisk ordgrupp.

ÅRGÅNG 26 · 1975: Björn Hagström, Att särskilja anonyma skrivare. Några synpunkter på ett paleografiskt-ortografiskt problem i medeltida isländska handskrifter, särskilt Isländska Homilieboken.-Gustaf Lindblad, Den rätta läsningen av Isländska Homilieboken.-Bo Ralph, En dikt av Steinpórr, 
islänning.-Kristinn Jóhannesson, Från Värmland till Borgarfjörður. Om Gustaf Frödings diktning i isländsk tolkning.

ÅRGÅNG 27 · 1976: Alan J. Berger, Old Law, New Law, and Hœnsa-Póris saga.-Heimir Pálsson, En översättares funderingar. Kring en opublicerad översättning av Sven Delblancs Åminne.-Kunishiro Sugawara, A Report on Japanese Translations of Old Icelandic Literature.-Evert Salberger, Ask Burlefot. En romanhjältes namn._Lennart Elmevik, Fisl. giogurr.

ÅRGÅNG 28 · 1977: Gustaf Lindblad, Centrala eddaproblem i 1970-talets forskningsläge.-Bo Ralph, Ett ställe i Skáldskaparmál 18.

ÅRGÅNG 29 · 1978: John Lindow, Old Icelandic páttr: Early Usage and Semantic History.-Finn Hansen, Naturbeskrivende indslag i Gísla saga Súrssonar.-Karl Axel Holmberg, Uppsala-Eddan i utgåva.

ÅRGÅNG 30 · 1979: Valter Jansson, Dag Strömbäck. Minnesord._Finn Hansen, Benbrud og bane i blåt.-Andrea van Arkel, Scribes and Statistics. An evaluation of the statistical methods used to determine the number of scribes of the Stockholm Homily Book._Eva Rode, Svar på artiklen »Scribes and Statistics».—Börje Westlund, Skrivare och statistik. Ett genmäle.

ÅRGÅNG 31 · 1980: Björn Högström, Fvn. bakkakolfr och skotbakki. Några glimtar från redigeringen av en norrön ordbok.-Alan J. Berger, The Sagas of Harald Fairhair.-IIkka Hirvonen, Om bruket av slutartikel i de äldsta norröna homilieböckerna IsIH och GNH.-Sigurgeir Steingrímsson, Tusen och en dag. En sagosamlings vandring från Orienten till Island._Jan Terje Faarlund, Subject and nominative in Oid Norse.-Lars-Erik Edlund, Askraka-ett engångsord i Egilssagan.

ÅRGÅNG 32 · 1981: Staffan Hellberg, Kungarna i Sigvats diktning. Till studiet av skaldedikternas språk och stil._Finn Hansen, Hrafnkels saga: del og helhed.Ingegerd Fries, Njals saga 700 år senare.

ÅRGÅNG 33 - 1982: Jan Paul Strid, Veiðar námo-ett omdiskuterat ställe i Hymiskviða._Madeleine G.Randquist, Om den (text)syntaktiska och semantiska strukturen i tre välkända isländska sagor. En skiss.-Sigurgeir Steingrímsson, Árni Magnusson och hans handskriftsamling.

ÅRGÅNG 34 · 1983: Peter Hallberg, Sturlunga saga - en isländsk tidsspegel.— Porleifur Hauksson, Anteckningar om Hallgrímur Pétursson.-Inger Larsson, Hrafnkels saga Freysgoða. En bibliografi.

ÅRGÅNG 35 · 1984: Lennart Elmevik, Einar Ólafur Sveinsson. Minnesord.Alfred Jakobsen, Noen merknader til Gísls páttr Illugasonar.-Karl-Hampus Dahlstedt, Bygden under Vatnajökull. En minnesvärd resa till Island 1954.Michael Barnes, Norn.-Barbro Söderberg, Till tolkningen av några dunkla passager i Lokasenna.

ÅRGÅNG 36 · 1985: Staffan Hellberg, Nesjavísur än en gång.-George S. Tate, Eldorado and the Garden in Laxness' Paradisarheimt.- Porleifur Hauksson, Vildvittror och Mattisrövare i isländsk dräkt. Ett kåseri kring en översättning av Ronja rövardotter.-Michael Barnes, A note on Faroese $/ \theta />/ \mathrm{h} /$._Björn 
Hagström, En färöisk-svensk ordbok. Rec. av Ebba Lindberg \& Birgitta Hylin, Färöord. Liten färöisk-svensk ordbok med kortfattad grammatik jämte upplysningar om språkets historiska bakgrund._Claes Åneman, Rec. av Bjarne Fidjestøl, Det norrøne fyrstediktet.

ÅRGÅNG 37 - 1986: Alfred Jakobsen, Om forfatteren av Sturlu saga._Michael P. Barnes, Subject, Nominative and Oblique Case in Faroese.-Marianne E. Kalinke, The Misogamous Maiden Kings of Icelandic Romance.-Carl-Otto von Sydow, Jon Helgasons dikt I Árnasafni. Den isländska texten med svensk översättning och kort kommentar.

ÅRGÅNG 38 - 1987: Michael P. Barnes, Some Remarks on Subordinate Clause Word-order in Faroese._Jan Ragnar Hagland, Njáls saga i 1970-og 1980-åra. Eit översyn över nyare forskning.-Per-Axel Wiktorsson, Om Torleiftåten.Karl-Hampus Dahlstedt, Davío Stefánssons dikt Konan, sem kyndir ofninn minn. Den isländska texten med svensk översättning och kort kommentar.

ÅRGÅG 39 - 1988: Alfred Jakobsen, Snorre og geografien.-Joan TurvillePetre, A Tree Dream in Old Icelandic.-Agneta Breisch, Fredlöshetsbegreppet i saga och samhälle._Tommy Danielsson, Magnús berfættrs sista strid._Ola Larsmo, Att tala i röret. En orättvis betraktelse av modern isländsk skönlitteratur. ÅRGÅNG 40 - 1989: Alv Kragerud, Helgdiktningen og reinkarnasjonen._Jan Nilsson, Guðmundr Ólafsson och hans Lexicon Islandicum — några kommentarer. ÅRGÅNG 41 · 1990: Jan Ragnar Hagland, Slaget på Pezinavellir i nordisk og bysantinsk tradisjon.-William Sayers, An Irish Descriptive Topos in Laxdœla Saga.-Carl-Otto von Sydow, Nyisländsk skönlitteratur i svensk översättning. En förteckning. Del 1.-Karl Axel Holmberg, Rec. av Else Nordahl, Reykjavík from the Archaeological Point of View.

ÅRGÅNG 42 · 1991: Stefan Brink, Den norröna bosättningen på Grönland. En kortfattad forskningsöversikt jämte några nya forskningsbidrag.-Carl-Otto von Sydow, Två dikter av Jón Helgason i original och svensk dräkt med kommentar.Carl-Otto von Sydow, Nyisländsk skönlitteratur i svensk översättning. En förteckning. Del 2._Nils Österholm, Torleiftåten i handskriften Add 4867 fol.— Lennart Elmevik, Rec. av Esbjörn Rosenblad, Island i saga och nutid.

ÅRGÅNG 43 - 1992: Anne Lidén, St Olav in the Beatus Initial of the Carrow Psalter-Michael P. Barnes, Faroese Syntax-Achievements, Goals and Problems.-Carl-Otto von Sydow, Nyisländsk skönlitteratur i svensk översättning. En förteckning. Del 3.

ÅRGÅNG 44 · 1993: Karl Axel Holmberg, Isländsk språkvård nu och förr. Med en sidoblick på svenskan._Páll Valsson, Islands älsklingsson sedd i ett nytt ljus. Några problem omkring den nya textkritiska utgåvan av Jónas Hallgrímssons samlade verk: Ritverk Jónasar Hallgrímssonar I-IV, 1989._William Sayers, Spiritual Navigation in the Western Sea: Sturlunga saga and Adomnán's Hinba.Carl-Otto von Sydow, Nyisländsk skönlitteratur i svensk översättning. En förteckning. Del 4.

ÅRGÅNG 45 · 1994: Kristín Bragadóttir, Skalden och redaktören Jón 
Porkelsson._-Ingegerd Fries, När skrevs sagan? Om datering av isländska sagor, särskilt Heiðarvígasagan.-Sigurður A. Magnússon, Sigurbjörn Einarsson som student i Uppsala på 1930-talet. Översättning, noter och efterskrift av Carl-Otto von Sydow.

ÅRGÅNG 46 - 1995: Ingegerd Fries, Biskop Gissur Einarsson och reformationen.-François-Xavier Dillmann, Runorna i den fornisländska litteraturen. En översikt.-William Sayers, Poetry and Social Agency in Egils saga SkallaGrímssonar.

ÅRGÅNG 47 · 1996: Lennart Elmevik, Valter Jansson. Minnesord._Jón Hnefill Aðalsteinsson, Blot i forna skrifter.-Gísli Pálsson, Språk, text och identitet i det isländska samhället.

ÅRGÅNG 48 - 1997: Lennart Elmevik, Anna Larsson. Minnesord.-Lennart Moberg, "Stóð und árhjalmi". Kring Hákonarmál 3:8.-Henric Bagerius, Vita vikingar och svarta sköldmör. Föreställningar om sexualitet i Snorre Sturlassons kungasagor._Páll Valsson, En runologs uppgång och fall._Björn Hagström, Något om färöisk lyrik - mest om Christian Matras.

ÅRGÅNG 49 · 1998: Veturliði Óskarsson, Om låneord og fremmed påvirkning på ældre islandsk sprog.-Jóhanna Barðdal, Argument Structure, Syntactic Structure and Morphological Case of the Impersonal Construction in the History of Scandinavian.-Jan Ragnar Hagland, Note on Two Runic Inscriptions relating to the Christianization of Norway and Sweden._-William Sayers, The ship heiti in Snorri's Skáldskaparmál.- Henrik Williams, Rec. av Snorres Edda. Översättning från isländskan och inledning av Karl G. Johansson och Mats Malm.

ÅRGÅNG 50 · 1999: Lennart Elmevik, Isländska sällskapet 50 år.-Bjarni Guðnason, Guðrún Ósvifursdóttir och Laxdæla Saga.-Veturliði Óskarsson, Verbet isländskt ské.-Henrik Williams, Nordisk paleografisk debatt i svenskt perspektiv. En kort överblick.-Carl-Otto von Sydow, Jón Helgasons dikt Kom milda nótt i svensk tolkning. - Veturliði Óskarsson, Är isländsk språkvård på rätt väg?-Gun Widmark, Isländsk-svenska kontakter i äldre tid.

ÅRGÅNG 51 · 2000: Lennart Elmevik, Vidar Reinhammar. Minnesord.-Peter Springborg, De islandske håndskrifter og "håndskriftsagen".-Gun Widmark, Om muntlighet och skriftlighet i den isländska sagan.-Judy Quinn, Editing the Edda-the case of Vôluspá.-Kirsten Wolf, Laughter in Old Norse-Icelandic Literature._Fjodor Uspenskij, Towards Further Interpretation of the Primordial Cow Auðhumla._Tom Markey, Icelandic sími and Soul Contracting._Björn Hagström, Den färöiska "Modersmålsordboken".

ÅRGÅNG 52 - 2001: Lennart Elmevik, Claes Åneman. Minnesord.-Lars Lönnroth, Laxness och isländsk sagatradition._François-Xavier Dillmann, Om hundar och hedningar. Kring den fornvästnordiska sammansättningen hundheiðinn.-Mindy MacLeod, Bandrúnir in Icelandic Sagas._Thorgunn Sncedal, Snorre Sturlasson-hövding och historiker.-Guðrún Kvaran, Omkring en doktorafhandling om middelnedertyske låneord i islandsk diplomsprog frem til år 1500 . 
ÅRGÅNG 53 - 2002: Veturliði Óskarsson, Studiosus antiqvitatum. Om Jón Ólafsson från Grunnavík, förebilden till Halldór Laxness sagoperson Jón Guðmundsson från Grindavik.-Pórgunnur Sncedal, From Rök to Skagafjörður: Icelandic runes and their connection with the Scandinavian runes of the Viking period.-Patrik Larsson, Det fornvästnordiska personbinamnet Kíkr._-Veturliði Óskarsson, Ur en eddadikts forskningshistoria.

ÅRGÅNG 54 · 2003: Henrik Williams, Än lever de gamla gudarna. Vikten av att forska om fornisländska.-Anna Helga Hannesdóttir, Islänningars attityder till språkliga normer.-Kristinn Jóhannesson, Halldór Laxness-samtidens spegel._Fredrik Charpentier Ljungqvist, Arngrímur Jónsson och hans verk.Adolfo Zavaroni, Communitarian Regime and Individual Power: Othinus versus Ollerus and Mithothyn.

ÅRGÅNG 55 - 2004: Heimir Pálsson, Några kapitel ur en oskriven bok.Staffan Fridell, At ósi skal á stemma. Ett ordspråk i Snorres Edda.-Agneta Ney, Mö-traditionen i fornnordisk myt och verklighet.-Martin Ringmar, Vägen via svenska. Om G. G. Hagalíns översättning av en finsk ödemarksroman.Svante Norr, A New Look at King Hákon's Old Helmet, the árhjálmr._Lasse Mårtensson, Två utgåvor av Jóns saga helga. En recension samt några reflexioner om utgivningen av nordiska medeltidstexter.

ÅRGÅNG 56 - 2005: Lennart Elmevik, Lennart Moberg. Minnesord.-Fredrik Charpentier Ljungqvist, The Significance of Remote Resource Regions for Norse Greenland.-Andreas Nordberg, Handlar Grimnesmål 42 om en sakral måltid?Daniel Sävborg, Kormáks saga - en norrön kärlekssaga på vers och prosa.Ingvar Svanberg och Sigurður Agisson, The Black Guillemot (Cepphus grylle) in Northern European Folk Ornithology.-Staffan Fridell, At ósi skal á stemma. Ett ordspråk i Snorres Edda. 2._Else Mundal, Literacy - kva talar vi eigentleg om? - Leidulf Melve, Literacy - eit omgrep til bry eller eit brysamt omgrep?

ÅRGÅNG 57 - 2006: Theodore M. Andersson, Viga-Glúms saga and the Birth of Saga Writing._Staffan Fridell, Fvn. hrynja och fsv. rynia. Om ett eddaställe och en flock i Södermannalagen.-Kirsten Wolf, The Color Blue in Old NorseIcelandic Literature.-Fredrik Charpentier Ljungqvist, Kristen kungaideologi i Sverris saga.-Lars Lönnroth, Sverrir's Dreams.-Arnved Nedkvitne, Skriftkultur i skandinavisk middelalder-metoder og resultater.-Lars Lönnroth, The Growth of the Sagas. Rec. av Theodore M. Andersson, The Growth of the Medieval Icelandic Sagas (1180-1280).-Anders Hultgård, rec. av François-Xavier Dillmann, Les magiciens dans l'Islande ancienne. Études

sur la représentation de la magie islandaise et de ses agents dans les sources littéraires norroises.-Heimir Pálsson, Den stora isländska litteraturhistorian. Rec. av Íslensk bókmenntasaga I-V. Red. Vésteinn Ólason, Halldór Guðmundsson \& Guðmundur Andri Thorsson. Sigurd Fries, Jón Aðalsteinn Jónsson och studiet av nyisländskan i Sverige.

ÅRGÅNG 58 - 2007: Heinrich Beck, Die Uppsala-Edda und Snorri Sturlusons Konstruktion einer skandinavischen Vorzeit._Gunnhild R $\phi$ the, Porgerðr 
Hölgabrúðr - the fylgja of the Háleygjar family._Michael Schulte, Memory culture in the Viking Ages. The runic evidence of formulaic patterns._Lennart Elmevik, Yggdrasill. En etymologisk studie.-Henrik Williams, Projektet Originalversionen av Snorre Sturlassons Edda? Studier i Codex Upsaliensis. Ett forskningsprogram.-Sverre Bagge, "Gang leader" eller "The Lord's anointed" i Sverris saga? Svar til Fredrik Ljungqvist og Lars Lönnroth._Heimir Pálsson, Tungviktare i litteraturhistorien. En krönika.

ÅRGÅNG 59 - 2008: Marianne Kalinke, Clári saga. A case of Low German infiltration. - Ármann Jakobsson, En plats i en ny värld. Bilden av riddarsamhället i Morkinskinna.-Margaret Cormack, Catholic saints in Lutheran legend. Postreformation ecclesiastical folklore in Iceland.-Tommy Danielsson, Social eller existentiell oro? Fostbrödradråp i två isländska sagor.-Mathias Strandberg, On the etymology of compounded Old Icelandic Óðinn names with the second component -fodr.-Susanne Haugen, Bautasteinn-fallos? Kring en tolkning av ett fornvästnordiskt ord._Lasse Mårtensson och Heimir Pálsson, Anmärkningsvärda suspensioner i DG 11 4to (Codex Upsaliensis av Snorra Edda) - spåren av en skriven förlaga? - Stefan Olsson, Harald hos jätten Dovre. Forntida initiationssymbolik i en medeltida tåt.-Bo-A. Wendt, Eddan och texttermerna. Kort terminologiskt genmäle till Henrik Williams._Michael Schulte, Literacy in the looking glass. Vedic and skaldic verse and the two modes of oral transmission.-Svanhildur Óskarsdóttir, rec. av Skaldic Poetry of the Scandinavian Middle Ages, volume VII: Poetry on Christian Subjects 1-2, ed. Margaret Clunies Ross._Else Mundal, rec. av Reflections on Old Norse Myths, red. Pernille Hermann, Jens Peter Schjødt och Rasmus Tranum Kristensen.Pernille Hermann, rec. av Learning and Understanding in the Old Norse World. Essays in Honour of Margaret Clunies Ross, ed. Judy Quinn, Kate Heslop och Tarrin Wills.

ÅRGÅNG 60 · 2009: Daniel Sävborg, Scripta Islandica 60.-Svanhildur Óskarsdóttir, To the letter. Philology as a core component of Old Norse studies. John McKinnell, Ynglingatal. A minimalist interpretation._Lars Lönnroth, Old Norse text as performance.-Elena Gurevich, From accusation to narration. The transformation of senna in Íslendinga pættir.-Theodore M. Andersson, The formation of the Kings' sagas._Helgi Skúli Kjartansson, Law recital according to Old Icelandic law. Written evidence of oral transmission?-Terry Gunnell, Ansgar's conversion of Iceland.-Helen F. Leslie, Border crossings. Landscape and the Other World in the Fornaldarsögur.-Tsukusu Itó, The Gosforth fishingstone and Hymiskviða. An example of inter-communicability between the Old English and Old Norse speakers.

ÅRGÅNG 61 · 2010: Helga Kress, Eine bewusste Antiregel. Die Stimme der Frau in Halldór Laxness Gedichten.-Margrét Eggertsdóttir, Hallgrímur Pétursson and Tormod Torfæus. Their scholarly friendship._Jan Ragnar Hagland, Hefi ek mark á máli mart. Litt om vokabular for særdrag ved folks språk og uttale i gammal-islandsk.-Olof Sundqvist, Om hängningen, de nio nätterna och den 
dyrköpta kunskapen i Hávamál 138-145. Stefanie Gropper, rec. av Jonatan Pettersson, Fri översättning i det medeltida Västnorden.-Jonatan Pettersson, rec. av Alexanders saga, Manuscripta Nordica 2, utg. Andrea de Leeuw van Weenen.-Lennart Elmevik, In memoriam. Oskar Bandle, Peter Foote, Björn Hagström.

ÅRGÅNG 62 · 2011: Ingvil Brügger Budal, Who is "I"? Translation of riddarasögur as a collective performance.-Finnur Friðriksson, Modern Icelandic: Stable or in a state of flux?-Svante Janson, The Icelandic calendar. Susanne Haugen, anm. av Kormaks saga. Historik och översättning av Ingegerd Fries._Heimir Pálsson, rec. av Úlfar Bragason, Ætt og saga: Um frásagnarfræði Sturlungu eða Íslendinga sögu hinnar miklu._Helgi Skúli Kjartansson, rec. av Rikke Malmros, Vikingernes syn på militær og samfund: Belyst gennem skjaldenes fyrstedigtning.-Lasse Mårtensson, rec. av Vår eldste bok. Skrift, miljø og biletbruk i den norske homilieboka. Bibliotheca Nordica 3, red. Odd Einar Haugen och Åslaug Ommundsen.-Rune Palm, rec. av. Poetry from the Kings' Sagas 2. From c. 1035-1300 (Skaldic Poetry of the Scandinavian Middle Ages II), ed. Kari Ellen Gade.-Úlfar Bragason, rec. av Margaret Clunies Ross, The Cambridge Introduction to the Old Norse-Icelandic Saga.

ÅRGÅNG 63 - 2012: Silvia Hufnagel, Icelandic society and subscribers to Rafn's Fornaldar sögur nordrlanda-Guðrún Kvaran, Nucleus latinitatis og biskop Jón Árnasons orddannelse-Heimir Pálsson, Om källor och källbehandling i Snorris Edda. Tankar kring berättelser om skapelsen-Triin Laidoner, The Flying Noaidi of the North: Sámi Tradition Reflected in the Figure Loki Laufeyjarson in Old Norse Mythology-Lars Wollin, Kringla heimsins-Jordennes krets-Orbis terrarum. The translation of Snorri Sturluson's work in Caroline SwedenPorleifur Hauksson, Implicit ideology and the king's image in Sverris sagaOlof Sundqvist, rec. av Annette Lassen, Odin på kristent pergament. En teksthistorisk studie-Kirsten Wolf, rec. av Rómverja saga, ed. Porbjörg Helgadóttir ÅRGÅNG 64 · 2013: Lennart Elmevik, Sigurd Fries. Minnesord-Daniel Sävborg, Rune Palm. Minnesord-Ulla Börestam, Gun Widmark. Minnesord-Agneta Ney, Bland ormar och drakar. En jämförande studie av Ramsundsristningen och Gökstenen-Judy Quinn, Death and the king: Grottasongr in its eddic contextBrittany Schorn, Divine Semantics. Terminology for the Human and the Divine in Old Norse Poetry-Kirsten Wolf, Body Language in Medieval Iceland. A Study of Gesticulation in the Sagas and Tales of Icelanders-Terry Gunnell, rec. av Merrill Kaplan, Thou Fearful Guest. Addressing the Past in Four Tales in Flateyjarbók-Bernt $\emptyset$. Thorvaldsen, rec. av Lars Lönnroth, The Academy of Odin. Selected Papers on Old Norse Literature-Vésteinn Ólason, rec. av The Poetic Edda. Vol. III. Mythological Poems II, ed. Ursula Dronke-Lars Wollin, rec. av Sif Rikhardsdottir, Medieval Translations and Cultural Discourse. The Movement of Texts in England, France and Scandinavia-Margaret Clunies Ross, rec. av Snorri Sturluson The Uppsala Edda DG 11 4to, ed. Heimir Pálsson ÅRGÅNG 65 · 2014: Pórdís Edda Jóhannesdóttir \& Veturliði Óskarsson, The 
Manuscripts of Jómsvíkinga Saga: A Survey_Sirpa Aalto, Jómsvíkinga Saga as a Part of Old Norse Historiography-Leszek P. Słupecki, Comments on Sirpa Aalto's Paper-Alison Finlay, Jómsvíkinga Saga and Genre-Judith Jesch, Jómsvíkinga Sogur and Jómsvíkinga Drápur: Texts, Contexts and IntertextsDaniel Sävborg, Búi the Dragon: Some Intertexts of Jómsvíkinga Saga-Alison Finlay, Comments on Daniel Sävborg's Paper-Jakub Morawiec, Danish Kings and the Foundation of Jómsborg-Władystaw Duczko, Viking-Age Wolin (Wollin) in the Norse Context of the Southern Coast of the Baltic Sea-Michael Lerche Nielsen, Runic Inscriptions Reflecting Linguistic Contacts between WestSlav Lands and Southern Scandinavia-Henrik Williams, Comments on Michael Lerche Nielsen's Paper - Jürgen Udolph, On the Etymology of JómsborgAlexandra Petrulevich, Comments on Jürgen Udolph's Paper-Marie Novotná \& Jiř́ Starý, Rendering Old Norse Nouns and Names in Translation into WestSlavic Languages

ÅRGÅNG 66 - 2015: Lise Gjedss $\phi$ Bertelsen, Sigurd Fafnersbane sagnet som fortalt på Ramsundsristningen-Anne-Sofie Gräslund, Kvinnorepresentationen på de senvikingatida runstenarna med utgångspunkt i Sigurdsristningarna-Terry Gunnell, Pantheon? What Pantheon? Concepts of a Family of Gods in PreChristian Scandinavian Religions - Tommy Kuusela, "Den som rider på Freyfaxi ska dö". Freyfaxis död och rituell nedstörtning av hästar för stup-Lars Lönnroth, Sigurður Nordals brev till Nanna-Jan Alexander van Nahl, The Skilled Narrator. Myth and Scholarship in the Prose Edda-William Sayers, Generational Models for the Friendship of Egill and Arinbjorn (Egils saga Skallagrímssonar)-Olof Sundqvist, The Pre-Christian Cult of Dead Royalty in Old Norse Sources: Medieval Speculations or Ancient Traditions?-Lars Lönnroth, rec. av Minni and Muninn: Memory in Medieval Nordic Culture, red. Pernille Herrmann, Stephen A. Mitchell \& Agnes S. Arnórsdóttir-Olof Sundqvist, rec. av Mikael Males: Mytologi i skaldedikt, skaldedikt i prosa. En synkron analys av mytologiska referenser i medeltida norröna handskrifter-Per-Axel Wiktorsson, rec. av The Power of the Book. Medial Approaches to Medieval Nordic Legal Manuscripts, red. Lena Rohrbach-Kirsten Wolf, rev. of Lasse Mårtensson. Skrivaren och förlagan: Norm och normbrott i Codex Upsaliensis av Snorra Edda

ÅRGÅNG 67 • 2016: Aðalheiður Guðmundsdóttir, Tales of Generations: A comparison between some Icelandic and Geatish narrative motifs-Eldar Heide, The term leizla in Old Norse vision literature - contrasting imported and indigenous genres?-Heimir Pálsson, DG 3 in memoriam-Sveinn Yngvi Egilsson, Jónas Hallgrímssons inre och yttre natur-Úlfar Bragason, Jón Halldórsson of Stóruvellir and his reading circle: Readings in the farming community in Iceland around 1870-Judy Quinn, rev. of Eddukvæði, red. Jónas Kristjánsson \& Vésteinn Ólason-Daniel Sävborg, rec. av Riddarasogur: The Translation of European Court Culture in Medieval Scandinavia, utg. Karl G. Johansson och Else Mundal-Heimir Pálsson, rec. av Pórunn Sigurðardóttir. Heiður og huggun: Erfiljóð, harmljóð og huggunarkvæði á 17. öld-Veturliði Óskarsson, anm. av Jón 
Ólafsson úr Grunnavík: AEvisögur ypparlegra merkismanna, utg. Gưrún Ása Grímsdóttir

ÅRGÅNG 68 - 2017: Lars Erik Edlund, Ingegerd Fries (1921-2016): Minnesord-Aðalheiður Guðmundsdóttir, Some Heroic Motifs in Icelandic Art-Daniel Sävborg, Blot-Sven: En källundersökning-Declan Taggart, All the Mountains Shake: Seismic and Volcanic Imagery in the Old Norse Literature of Pórr-Elín Bára Magnúsdóttir, Forfatterintrusjon i Grettis saga og paralleller i Sturlas verker-Haukur Porgeirsson \& Teresa Dröfn Njarðvík, The Last Eddas on Vellum-Heimir Pálsson, Reflections on the Creation of Snorri Sturluson's Prose Edda-Magnus Källström, Monumenta lapidum aliquot runicorum: Om runstensbilagan i Verelius' Gothrici \& Rolfi Westrogothiae Regum Historia (1664)Matteo Tarsi, Creating a Norm for the Vernacular: Some Critical Notes on Icelandic and Italian in the Middle Ages-Olof Sundqvist, Blod och blot: Blodets betydelse och funktion vid fornskandinaviska offerriter-Sveinn Yngvi Egilsson, Kan man skriva pastoral poesi så nära Nordpolen? Arkadiska skildringar i isländska dikter från artonhundratalet-Tommy Kuusela, "Pá mælti Míms hơfuð": Jätten Mimer som kunskapsförmedlare i fornnordisk tradition-Lars Lönnroth, rec. av A Handbook to Eddic Poetry: Myths and Legends of Early Scandinavia, red. Carolyne Larrington, Judy Quinn \& Brittany Schorn-Lars-Erik Edlund, rec. av Islänningasagorna. Samtliga släktsagor och fyrtionio tåtar. Red. Kristinn Jóhannesson, Gunnar D. Hansson \& Karl G. Johansson-Aðalheiður Guðmundsdóttir, rev. of Agneta Ney. Bland ormar och drakar: Hjältemyt och manligt ideal $i$ berättartraditioner om Sigurd Fafnesbane

ÅRGÅNG 69 - 2018: Klas af Edholm, Att rista blodörn: Blodörnsriten sedd som offer och ritualiserad våldspraktik i samband med maktskiften i fornnordisk tradition-Jan Ragnar Hagland, Litt om kvinnekroppen i norrøn leksikografisk samanheng - Luke John Murphy, Paganism at Home: Pre-Christian Private Praxis and Household Religion in the Iron-Age North-Ludger Zeevaert, Eine deutsche Zusammenfassung von Njáls saga im Manuskript Rostock Mss. philol. 78/2Heimir Pálsson, Nordens latin-Sigurður Gylfi Magnússon, What Takes Place, When Nothing Happens? The importance of late modern manuscript culturePernille Hermann, rec. av Jón Karl Helgason. Echoes of Valhalla. The Afterlife of the Eddas and Sagas-Mikael Males, rec. av Skaldic Poetry of the Scandinavian Middle Ages, 3: Poetry from Treatises on Poetics, utg. Kari Ellen Gade med Edith Marold-Alexandra Petrulevich, rec. av Studies in the transmission and reception of Old Norse literature. The Hyperborean muse in European culture, red. Judy Quinn \& Adele Cipolla-Olof Sundqvist, rec. av Declan Taggart. How Thor Lost his Thunder. The Changing Faces of an Old Norse God-Vésteinn Ólason, rec. av Poetry in fornaldarsögur. Part 1 and 2, utg. Margaret Clunies Ross

ÅRGÅNG 70 - 2019: Ada Kan, Lars Lönnroth och Agneta Ney, Elena Gurevich (1957-2018). Minnesord-Anders Hultgård, Om Vafprúðnismál-Andras Mortensen, Færeyinga saga som historisk kilde: En vurdering af sagaens ophavssituation og politiske miljø-Guðmundur Ólafsson og Lise Gjedss $\phi$ Bertelsen, 
Det henrettede par i dobbeltgravhøjene i Kópavogur syd for Reykjavík i ÍslandHubert Seelow, Sjö plánetur í ljóðmaelum: Ein isländisches Gedicht über die Planetenkinder. Mit einem Exkurs: Kritische Anmerkungen zur Laienastrologie und Laienphilologie-Matteo Tarsi, Instances of loanword/native word textual variation in the manuscript transmission of Egils saga Skallagrímssonar and Gísla saga Súrssonar-Marianne Kalinke, rev. of Natalie M. Van Deusen. The Saga of the Sister Saints. The Legend of Martha and Mary Magdalen in Old Norse-Icelandic Translation-Olof Sundqvist, rec. av Anders Hultgård. Midgård brinner. Ragnarök i religionshistorisk belysning 
